Yuri Rugai Marinho

\title{
INCENTIVOS POSITIVOS PARA A PROTEÇÃO DO MEIO AMBIENTE
}

Dissertação de Mestrado

Orientadora: Professora Associada Patrícia Faga Iglecias Lemos

UNIVERSIDADE DE SÃO PAULO

Faculdade de Direito

São Paulo

2014 


\title{
Yuri Rugai Marinho
}

\section{INCENTIVOS POSITIVOS PARA A PROTEÇÃO DO MEIO AMBIENTE}

\begin{abstract}
Dissertação apresentada à Banca Examinadora da Faculdade de Direito da Universidade de São Paulo, como exigência parcial para obtenção do título de Mestre na área de concentração: Direito Civil, sob a orientação da Professora Associada Patrícia Faga Iglecias Lemos.
\end{abstract}

São Paulo 
INCENTIVOS POSITIVOS PARA

A PROTEÇÃO DO MEIO AMBIENTE

YURI RUGAI MARINHO

DATA:

BANCA EXAMINADORA:

$1^{a}$ Examinadora:

Orientadora: Patrícia Faga Iglecias Lemos

$2^{\mathrm{a}}$ Examinador(a):

$3^{\mathrm{a}}$ Examinador(a): 


\section{AGRADECIMENTOS}

À Professora Patrícia Faga Iglecias Lemos, minha orientadora, por ter acreditado sempre no meu potencial como pesquisador e jurista, e por ter auxiliado, de modo generoso e presente, a transformar minhas ideias em texto jurídico. Agradeço especialmente por todas as suas contribuições durante o processo de construção desta dissertação. Sua experiência, seu conhecimento e sua atuação no Direito Ambiental são inspiradores.

À Professora Ana Maria de Oliveira Nusdeo, do Departamento de Direito Econômico, Financeiro e Tributário, da Faculdade de Direito da Universidade de São Paulo, e ao Professor Marcelo Gomes Sodré, da Faculdade de Direito da Pontifícia Universidade Católica de São Paulo, por suas lições transformadoras e por terem feito do meu exame de qualificação um inestimável momento de compartilhamento e aprendizado.

À Roberta Danelon Leonhardt, sócia do Departamento Ambiental do escritório Machado, Meyer, Sendacz e Opice Advogados, onde trabalhei por 4 anos como advogado, pela discussão e pelo acolhimento das minhas ideias. Agradeço também pelas oportunidades de publicação conjunta de artigos e opiniões.

À Carolina Castelo Branco, advogada do escritório Machado, Meyer, Sendacz e Opice Advogados, com quem trabalhei, por todo o auxílio em pesquisas, discussões e demais atividades acadêmicas no escritório e na Faculdade de Direito da Universidade de São Paulo.

Aos amigos do escritório Machado, Meyer, Sendacz e Opice Advogados, por compartilharem os esforços da advocacia ambiental.

Aos colegas de pós-graduação, por terem compartilhado um caminho permeado de tropeços e conquistas e recheado de discussões.

Aos colegas Guillermo Tejeiro, Paula Lavratti, Marcia Stanton e Paulo Rama, do Instituto "O Direito por um Planeta Verde", pela oportunidade de participar, como consultor do Estado de São Paulo, do programa "Sistemas Estaduais de PSA: diagnóstico, lições aprendidas e desafios para uma futura legislação". 
Aos colegas Guarany Osório e Leeward Wang, do Centro de Estudos em Sustentabilidade da Fundação Getúlio Vargas (FGV); Helena Carrascosa e Araci Kamiyama, da Coordenadoria de Biodiversidade e Recursos Naturais (CBRN) da Secretaria de Meio Ambiente do Estado de São Paulo; Fatima Aparecida Carrara, do Fundo Estadual de Prevenção e Controle da Poluição (FECOP); Astrid Zwager, do Banco Mundial e Fernando Salles Rosa, da Secretaria de Meio Ambiente do Município de Ibiúna, Estado de São Paulo, pelas entrevistas, contribuições e pelo inestimável auxílio no levantamento de informações sobre pagamento por serviços ambientais no Estado de São Paulo.

À Vivian Calderoni, amiga que sempre forneceu suporte e auxílio no desenvolvimento desta dissertação. Foi, também, companheira nos estudos acadêmicos na seara ambiental nos primeiros anos da Graduação na Faculdade de Direito da Universidade de São Paulo.

À Lia Helena Monteiro de Lima Demange, amiga sempre disposta a contribuir com meus estudos e projetos. Foi companheira e prestativa na revisão de textos e sempre presente nos estudos acadêmicos na Faculdade de Direito da Universidade de São Paulo e grupos de estudos independentes. Sua mãe, Denise, também contribuiu com ensinamentos e estímulo ao meu desenvolvimento acadêmico.

Ao Matheus Carvalho, amigo sincero, cujo altruísmo ultrapassa as expectativas de todos nós. Sua ajuda será sempre lembrada.

Com todo o meu amor e admiração, à minha mãe, Flavia, e ao meu pai, Ivan, exemplos de pessoas que se dedicam ao bem, à honestidade, ao conhecimento e à evolução pessoal. Pelo apoio incondicional e compreensão infinita. São, acima de tudo, minha inspiração para a vida.

Aos meus irmãos Raoni e Dier, pelo convívio diário e pela dedicação à vida em família.

À Sara, pela paciência, compreensão e companheirismo nos momentos mais difíceis na elaboração desta dissertação. 
Aos meus pais, com muito carinho, pelo apoio incondicional. 


\section{RESUMO}

O objetivo do presente trabalho consistiu na análise das ferramentas utilizadas pelo Direito para a proteção do meio ambiente. Para a sua consecução, estudou-se doutrina, legislação, jurisprudência e dados fáticos disponíveis em veículos de mídia digital ou impressa e sítios eletrônicos oficiais. Foram, também, conduzidas entrevistas com autoridades públicas do Estado de São Paulo e visitas a proprietários de imóveis rurais.

As constatações revelaram a pluralidade de ângulos sob os quais a temática da proteção do meio ambiente pode ser encarada. As principais contribuições desta pesquisa consistiram na demonstração da insuficiência do sistema de sanções negativas para a proteção do meio ambiente, sendo indispensável a criação de incentivos positivos às práticas favoráveis ao meio ambiente. Os principais temas desta dissertação foram tratados em capítulos próprios e puderam ser assim elencados: (i) o Direito Positivo e as normas jurídicas - comentários quanto à positivação do Direito e a importância das normas -; (ii) a evolução do Direito Ambiental no Brasil e a sua finalidade - tendências do Direito Ambiental no Brasil e a busca da proteção ambiental -; (iii) o regime de sanções negativas - maneira como as sanções negativas são aplicadas e seus resultados -; (iv) o regime de incentivos - maneira como os incentivos positivos são aplicados atualmente e propostas de utilização em outros casos -; (v) experiência brasileira na concessão de incentivos ambientais - as previsões normativas já existentes e os resultados alcançados no Brasil -; e (vi) o Direito Internacional Ambiental e a experiência dos países na concessão de incentivos comentários sobre tratados internacionais e normas internas de outros países que utilizam incentivos positivos para a proteção do meio ambiente. Foi apresentado um conjunto de reflexões críticas com base no material analisado e no diálogo com autoridades públicas, acadêmicos e cidadãos brasileiros na vivência profissional do pesquisador.

Palavras-chave: Incentivos - Direito Ambiental - Proteção do meio ambiente - Eficácia das normas - Direito Internacional Ambiental - Sanções. 


\section{ABSTRACT}

The scope of this work was to study the tools provided by the Law for the protection of the environment. For this purpose, this work analyzed the following material: doctrine, legislation, jurisprudence and factual data available on digital or printed media channels, as well as official websites. Interviews with public authorities of the State of São Paulo and visits to rural properties were also carried out. The findings disclosed various points of view regarding environmental protection. The main contributions of this research consisted in demonstrating the failure of the system based on negative sanctions for the protection of the environment, reason why positive incentives for environmentally friendly practices must be created. This dissertation discoursed on the following main themes: (i) the Positive Law and the legal rules - comments on the positivation of the Law and the importance of statutes -; (ii) the evolution of the Environmental Law in Brazil and its goal - tendencies of the Environmental Law in Brazil and the pursuit of environmental protection -; (iii) the sanctions regime - how penalties are applied and what are their results -; (iv) the incentives regime - how positive incentives are currently applied and proposals for enforcement -; (v) the Brazilian experience in the enactment of environmental incentives - the legal rules currently applicable and the results observed in Brazil -; and (vi) the International Environmental Law and the experience of countries in the giving of incentives - comments on international treaties and domestic rules of countries that enacted positive incentives for the protection of the environment. The study formulated critical findings based on the material analyzed and on discussions held with public authorities, students and citizens during the professional experience of the researcher.

Keywords: Incentives - Environmental Law - Protection of the environment Effectiveness of the rules - International Environmental Law - Penalties. 
INTRODUÇÃO........................................................................................................................11

METODOLOGIA........................................................................................................... 19

CAPÍTULO 1 - O DIREITO POSITIVO E AS NORMAS JURÍDICAS......................20

1.1 O Direito positivo ..........................................................................................................20

1.2 A norma jurídica................................................................................................................22

1.3 A evolução do Estado e das normas jurídicas .........................................................26

1.4 A eficácia das normas jurídicas....................................................................................35

CAPÍTULO 2 - A EVOLUÇÃO DO DIREITO AMBIENTAL NO BRASIL E A SUA

FINALIDADE ..............................................................................................................38

2.1 Princípios resultantes da evolução do Direito Ambiental e a responsabilidade sem dano .....................................................................................................................42

CAPÍTULO 3 - O REGIME DE SANÇÕES NEGATIVAS ...........................................48

3.1 As sanções negativas no Direito Ambiental...............................................................53

3.2 A Lei de Crimes Ambientais .......................................................................................60

CAPÍTULO 4 - O REGIME DE INCENTIVOS........................................................65

4.1 Conceito de incentivos ..........................................................................................65

4.2 Tipos de incentivos.................................................................................................................68

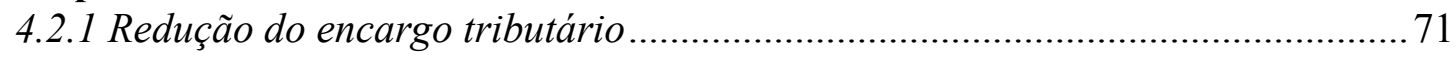

4.2.2 Redução dos procedimentos burocráticos de regularização da propriedade ....73

4.2.3 Concessão de facilidades na obtenção de empréstimos financeiros ....................74

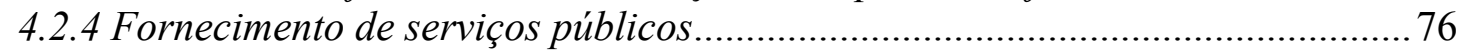

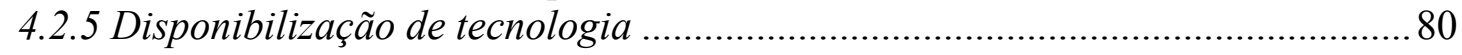

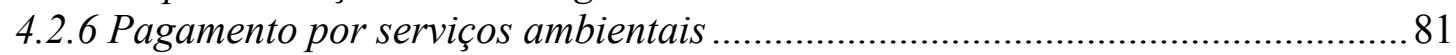

4.2.7 Criação de lista ou de ranking das pessoas com boas práticas ambientais........84

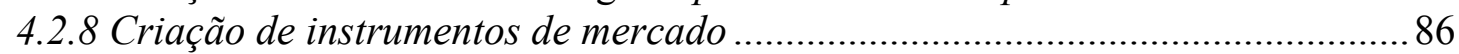

CAPÍTULO 5 - A EXPERIÊNCIA BRASILEIRA NA CONCESSÃO DE

INCENTIVOS AMBIENTAIS ..................................................................................90

5.1 Normas vigentes que concedem incentivos ambientais ............................................90

5.2 Incentivos na Lei de Crimes Ambientais ................................................................98

5.3 A experiência do Estado de São Paulo com o PSA ...................................................103

5.4 Doutrina favorável: principais argumentos sobre a concessão de incentivos

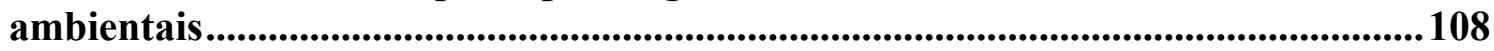

5.5 Doutrina desfavorável: principais argumentos sobre a concessão de incentivos ambientais................................................................................................................. 112

5.6 Da necessidade de análises de custo-benefício nas políticas públicas ambientais

CAPÍTULO 6 - O DIREITO INTERNACIONAL AMBIENTAL E A EXPERIÊNCIA DOS PAÍSES NA CONCESSÃO DE INCENTIVOS.....................................................120

6.1 Incentivos no Direito internacional Ambiental....................................................120

6.2 Incentivos na Convenção sobre diversidade biológica ............................................123

6.3 Incentivos na Convenção-Quadro das Nações Unidas sobre Mudança do Clima 
6.4 Experiência da Costa Rica ......................................................................................126

6.5 Experiência dos Estados Unidos da América ............................................................. 127

6.5.1 Experiência com o sistema da melhor tecnologia disponível (best available

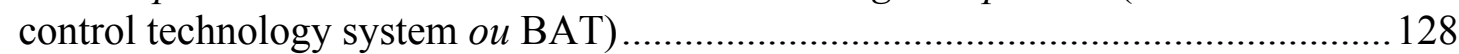

6.5.2 Experiência com incentivos econômicos ....................................................... 130

6.5.3 Experiência com serviços ecossistêmicos ....................................................... 134

6.5.4 Experiência com a imputação de encargos ..................................................... 136

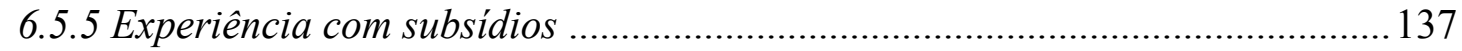

6.6 Experiência da União Europeia..........................................................................138

6.6.1 O caso especifico da Alemanha .................................................................... 140

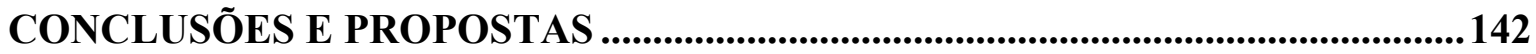

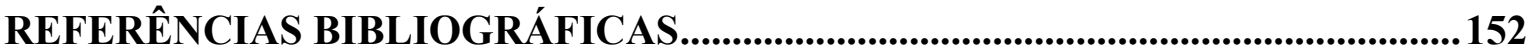




\section{INTRODUÇÃO}

O tema da presente dissertação insere-se no rol dos problemas ambientais enfrentados pela sociedade moderna e reflete o papel do Direito, pelo processo de positivação, na prevenção de danos e na proteção ambiental. O poder da tecnologia e o desenvolvimento de máquinas e empreendimentos de grandes magnitudes possibilita a ocorrência de danos irreversíveis e de extensa proporção, fato que prejudica o ambiente e, consequentemente, o homem. Com isso, pagam a sociedade e o Estado.

É notória, nos tempos atuais, a significativa evolução do Direito Ambiental brasileiro. A cada ano, um número crescente de entidades civis e de órgãos públicos passa a tratar da questão do ambiente, inserindo o Brasil no papel de pioneiro no cenário jurídico internacional.

Não à toa, por exemplo, que o País foi sede de duas das mais importantes conferências internacionais sobre meio ambiente: a Conferência das Nações Unidas sobre Meio Ambiente e Desenvolvimento (popularmente conhecida por ECO-92) e a Conferência das Nações Unidas sobre Desenvolvimento Sustentável (apelidada de Rio + 20), ambas ocorridas na cidade do Rio de Janeiro, em 1992 e 2012, respectivamente.

No ano de 2012, o mundo todo acompanhou as discussões e embates em torno do novo Código Florestal brasileiro, instituído pela Lei $\mathrm{n}^{\mathrm{o}}$ 12.651/2012 ${ }^{1}$.

Paralelamente a esta evolução, cresce em ritmo ainda mais acelerado o poder da indústria e da tecnologia e, por consequência, a preocupação da sociedade em relação aos danos ambientais. Como ressalta Teresa Ancona Lopez ${ }^{2}$, inspirada em Ulrich Beck, vivemos atualmente na sociedade de risco, em que o medo e a incerteza prevalecem, muito em razão das descobertas e dúvidas relacionadas à internet, à saúde, às epidemias, ao terrorismo, à mudança do clima etc.

\footnotetext{
1 BRASIL. Lei $\mathrm{n}^{\mathrm{o}}$ 12.651, de 25 de maio de 2012. Disponível em: $<$ http://www.planalto.gov.br/ccivil_03/_ato2011-2014/2012/lei/112651.htm>. Acesso em: 31 março 2014.

2 LOPEZ, Teresa Ancona. Princípio da precaução e evolução da responsabilidade civil. São Paulo: Quartier Latin, 2010, p. 36.
} 
Na mesma linha, a filosofia de Ávila Coimbra relata:

A expansão descontrolada do consumo desperta novas tecnologias para atenderem à demanda. E aí se processa uma reação em cadeia. A expansão descontrolada da tecnologia sem finalidade maior prega sustos ao homem, cria problemas sociais e políticos, interfere seriamente nas relações internacionais, por causa do desassossego e da competição que cria. A grita que toma conta dos meios de comunicação alarma-o, não porque sinta as dores da Mãe-Terra, mas só porque receia ver-se privado de recursos e comodidades ${ }^{3}$.

Marcelo Gomes Sodré afirma que "pobreza e consumismo convivem lado a lado e ambos degradam o meio ambiente" 4 .

Neste aspecto, é mister que seja evitada, a todo custo, a ocorrência de danos ambientais que, nas palavras de Patrícia Faga Iglecias Lemos,

corresponde à alteração adversa mensurável de um recurso natural ou a deteriorização mensurável do serviço de um recurso natural, que ocorram direta ou indiretamente ${ }^{5}$.

Ou, aprofundando-se a definição, são

danos causados às espécies e habitats naturais protegidos, isto é, quaisquer danos causados com efeitos significativos adversos para a consecução ou à manutenção do estado de conservação favorável desses habitats ou espécies, não incluídos os efeitos adversos previamente identificados que resultem de um ato de um operador expressamente autorizado pelas autoridades competentes ${ }^{6}$.

É preciso lembrar que a atividade econômica, em sua essência, serve para melhorar o bem estar dos indivíduos que compõem a sociedade ${ }^{7}$.

\footnotetext{
${ }^{3}$ COIMBRA, Ávila. O outro lado do meio ambiente. Campinas: Millennium, 2008, p. 229.

${ }^{4}$ SODRÉ, Marcelo Gomes. Padrões de consumo e meio ambiente. In: MARQUES, Claudia Lima (Coord.). Revista de Direito do Consumidor, n. 31. São Paulo: RT, 1999, p. 25.

${ }^{5}$ LEMOS, Patrícia Faga Iglecias. Direito ambiental: responsabilidade civil e proteção ao meio ambiente. 3. ed. São Paulo: RT, 2010, p. 106.

${ }^{6}$ Idem, ibidem.

${ }^{7}$ FREEMAN III, A. Myrick. Economics, Incentives and Environmental Regulation. In: VIG, Norman J.; KRAFT, Michael (Editors). Environmental policy: new directions for the twenty-first century. 4th ed. Washington, D.C.: CQ Press, 2006, p. 191. Tradução livre do autor desta Dissertação. Do original: "(...) the purpose of economic activity is to increase the well-being of the individuals who make up the society (...)".
} 
Desta forma, atitudes de prevenção e precaução tornam-se importantes vias para garantir a incolumidade do ambiente e possibilitar a vida humana no Planeta Terra. Não será menos custoso à sociedade evitar a ocorrência de danos ambientais do que investigálos, corrigi-los, buscar o retorno ao status quo ante e punir o infrator responsável?

Afinal, todos esses procedimentos devem ser tomados após a ocorrência de um dano ambiental.

É imperioso que o Direito conte com normas que garantam a proteção do meio ambiente e do homem, bem como que estabeleçam, com racionalidade, equilíbrio e eficácia, regras de prevenção, precaução e responsabilização dos infratores. Em outras palavras, é necessária a positivação das obrigações e dos estímulos para a garantia de um meio ambiente equilibrado.

Todavia, a edição de tais normas é um desafio para o legislador e o aplicador do Direito, motivo pelo qual são necessários estudos e discussões sobre o tema.

Como bem apontado por Terence Dorneles Trennepohl, a norma jurídica fornece a estrutura lógica de que se vale o Direito para realizar
seus institutos e anseios. A segurança jurídica das relações intersubjetivas
depende da logicidade e da aplicabilidade dessa norma ${ }^{8}$.

E, complementa, "as normas jurídicas constituem técnicas de motivação social, instrumentos para induzir os homens a se comportar de determinada maneira"9.

Daí se percebe que um primeiro passo indispensável é o estudo da norma, de sua estrutura e eficácia, na qualidade de elemento essencial da ordem jurídica.

As normas que compõem um ordenamento jurídico podem ter natureza protetivorepressiva ou promocional ${ }^{10}$.

\footnotetext{
8 TRENNEPOHL, Terence Dorneles. Incentivos fiscais no direito ambiental: para uma matriz energética limpa e o caso do etanol brasileiro. São Paulo: Saraiva, 2011, p. 33.

${ }^{9}$ Idem, p. 35.

${ }^{10}$ BOBBIO, Norberto. Da estrutura à função: novos estudos de teoria do direito. Barueri: Manole, 2007, p. 3.
} 
No primeiro caso, existem três modos típicos de impedir uma ação não desejada: torná-la impossível, torná-la difícil ou torná-la desvantajosa. Por outro lado, o ordenamento promocional busca atingir os mesmos fins por três operações contrárias, isto é, buscando tornar a ação desejada necessária, fácil ou vantajosa.

Quanto ao ponto, questiona-se: deve o Estado limitar-se a estabelecer comandos, proibições ou limites para atingir seus fins? Agindo assim, o Estado garantiria a felicidade, o bem estar e os bons costumes da população?

É preciso refletir o papel do Estado na atual sociedade e os riscos de sua limitação à atuação protetivo-repressiva.

Tradicionalmente, o ordenamento jurídico voltou-se, quase que exclusivamente, para a punição da conduta que trouxesse danos ao meio ambiente ou ao homem, sem muitos questionamentos quanto às causas do ato, às dificuldades do particular ou mesmo a um dos principais escopos das normas, qual seja, a prevenção e a reparação dos danos. Utiliza-se de instrumentos de comando e controle, com a finalidade de garantir o cumprimento dos objetivos de determinada política.

Todavia, é preciso considerar que a previsão de incentivos para uma conduta desejada pode trazer mais benefícios ao meio ambiente, além de trazer eficácia às normas ambientais e garantir sua aplicabilidade, com menor onerosidade aos cofres públicos. Defende-se ser medida válida a previsão de incentivos para que não sejam praticados delitos ambientais, à maneira como tem ocorrido no Direito Internacional Ambiental. Por certo, existem situações em que a concessão de uma sanção positiva (incentivo) traz mais resultados benéficos ao meio ambiente do que a imposição de uma sanção negativa (castigo). Tal fato pode ser constatado por meio da análises dos custos e dos benefícios.

Neste sentido, é questionável a eficácia da imposição isolada de penalidades isto é, sem o estímulo ao cumprimento das normas -, principalmente em vista do verdadeiro objetivo do Direito Ambiental, qual seja, a proteção do meio ambiente. 
Da mesma forma, é criticável a imposição de multas em valores vultosos, uma vez que, como já estudado por respeitados nomes do Direito e da Economia, o efeito de tal imposição pode ser perverso. Multas desproporcionais podem gerar clandestinidade e, por consequência, prejuízos sociais, ambientais, fiscais, trabalhistas, dentre tantos outros.

É certo que o Direito deve trazer normas punitivas, seja para fins educativos, seja para fins de repressão à condutas indesejáveis. Todavia, é questionável a eficiência de um modelo exclusivamente repressor, principalmente nos casos de difícil reparação dos danos, tal como ocorre nas questões ambientais.

O Direito tem função de indutor de comportamentos, de forma que o legislador e seu aplicador não podem eximir-se dessa responsabilidade. Entretanto, a aplicação de penalidades não pode ser o único meio utilizado, principalmente quando já não são alcançados os efeitos esperados.

A pessoa - física ou jurídica, de direito público ou privado - que respeita a legislação e não pratica ações que causem prejuízos ao meio ambiente tem importante papel na sociedade, seja para evitar a ocorrência de dano ambiental, seja para garantir a proteção do ambiente.

Essa pessoa merece um reconhecimento e estímulo para que continue contribuindo. Ou seja, merece ser estimulada toda pessoa cuja conduta seja sadia ao ambiente, como forma de reconhecimento por sua contribuição à sociedade. Seja destacado que incentivar a conduta positiva ao meio ambiente é incentivar, indiretamente, a prevenção dos danos ambientais. Em outras palavras, evitar a ocorrência de danos.

Não se defende, porém, a criação de uma espécie de salário a todo cidadão que cumpra com o dever constitucional de proteção ao meio ambiente. O intuito é, somente, incentivar as boas práticas ambientais. E isso pode ser feito de várias formas, todas elas com o escopo comum de amenizar as dificuldades enfrentadas pelo cidadão médio, o bonus pater familias do Direito romano. É possível citar, a título de exemplo: (i) pagamento por serviços ambientais; (ii) redução do encargo tributário; (iii) redução dos procedimentos burocráticos de regularização da propriedade; (iv) concessão de facilidades 
na obtenção de empréstimos financeiros e (v) criação de lista ou ranking das pessoas com boas práticas ambientais.

Tais incentivos podem evitar que seja consumado o dano ambiental, retirando a necessidade de processos administrativos, judiciais e investigatórios para apuração e responsabilização do infrator - os quais, insta apontar, são de elevada complexidade, em vista da frequente dificuldade em comprovar a extensão do dano causado e o seu nexo de causalidade com a conduta do infrator.

Sabe-se, inclusive, valendo-se das palavras de Patrícia Faga Iglecias Lemos, que

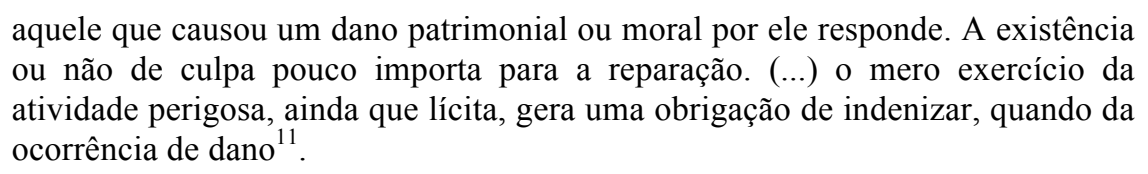

Trata-se de responsabilidade objetiva.

Por isso, a concessão de incentivos às pessoas que praticam condutas próambiente parece ser mais válida para a sociedade e para o Direito Ambiental do que a penalização dos infratores, pois garante que não ocorram danos ambientais.

Já são numerosas as situações em que o ordenamento jurídico brasileiro prevê incentivos para condutas saudáveis ao ambiente. A título de exemplo, podem ser citadas ${ }^{12}$ : (i) a Lei da Política Nacional do Meio Ambiente (Lei $n^{\circ} 6.938 / 1981^{13}$ ), que previu como princípio a concessão de incentivos ao estudo e à pesquisa de tecnologias orientadas para o uso racional e a proteção dos recursos ambientais (artigo $2^{\circ}$, inciso VI); (ii) a Lei $\mathrm{n}^{\mathrm{o}}$ $11.428 / 2006^{14}$, que estabelece a concessão de incentivos econômicos para estimular a proteção e o uso sustentável do Bioma Mata Atlântica (artigo 33) e incentivos creditícios para o proprietário ou posseiro que tenha vegetação primária ou secundária em estágios avançado e médio de regeneração do Bioma Mata Atlântica (artigo 41, inciso I); (iii) a Lei

\footnotetext{
${ }^{11}$ LEMOS, Patrícia Faga Iglecias. Direito ambiental... cit., p. 127.

${ }^{12}$ Referidas normas foram abordadas em detalhe no item 5.1.

13 BRASIL. Lei $\mathrm{n}^{\circ} 6.938$ de 31 de agosto de 1981. Disponível em: <http://www.planalto.gov.br/ccivil_03/leis/16938.htm>. Acesso em: 31 março 2014.

14 BRASIL. Lei $\mathrm{n}^{\mathrm{o}} 11 . \overline{4} 28$, de 22 de dezembro de 2006. Disponível em: <http://www.planalto.gov.br/ccivil_03/_ato2004-2006/2006/lei/111428.htm>. Acesso em: 31 março 2014.
} 
$n^{\mathrm{o}} 12.187 / 2009^{15}$, que instituiu a Política Nacional sobre Mudança do Clima, a qual prevê como diretriz a utilização de instrumentos financeiros e econômicos para promover ações de mitigação e adaptação à mudança do clima (artigo $6^{\circ}$, inciso VI); (iv) a Política Nacional de Resíduos Sólidos, instituída pela Lei $\mathrm{n}^{\mathrm{o}} 12.305 / 2010^{16}$, com inúmeros dispositivos de incentivos que foram criados para possibilitar o gerenciamento dos resíduos sólidos em território brasileiro (artigos $7^{\circ}$ e $8^{\circ}$ ); (v) a Lei $n^{\circ} 12.512 / 2011^{17}$, que instituiu o Programa de Apoio à Conservação Ambiental e autoriza que a União transfira recursos financeiros e disponibilize serviços de assistência técnica a famílias em situação de extrema pobreza que desenvolvam atividades de conservação de recursos naturais no meio rural (artigo $2^{\circ}$ ); (vi) a Lei $\mathrm{n}^{\mathrm{o}} 12.651 / 2012^{18}$, que instituiu o Novo Código Florestal Brasileiro, a qual permite ao governo federal instituir "programa de apoio e incentivo à conservação do meio ambiente, bem como para adoção de tecnologias e boas práticas que conciliem a produtividade agropecuária e florestal, com redução dos impactos ambientais, como forma de promoção do desenvolvimento ecologicamente sustentável” (artigo 41) e (vii) a Lei $n^{\mathrm{o}} 12.854 / 2013^{19}$, que "fomenta e incentiva ações que promovam a recuperação florestal e a implantação de sistemas agroflorestais em áreas rurais desapropriadas pelo Poder Público e em áreas degradadas em posse de agricultores familiares assentados, de quilombolas e de indígenas" (artigo $1^{\circ}$ ).

Observa-se, com isso, que o governo tem lançado mão de incentivos de caráter ambiental para garantir a proteção do meio ambiente. Especificamente no caso da Lei ${ }^{\circ}$ $12.512 / 2011^{20}$, foi ainda apresentado um mecanismo que traz efeitos sociais positivos.

No campo jurídico internacional, sejam apontadas: (i) a Convenção sobre Diversidade Biológica $^{21}$, assinada na cidade do Rio de Janeiro, em 1992, que trouxe a

15 BRASIL. Lei $\mathrm{n}^{\mathrm{o}}$ 12.187, de 29 de dezembro de 2009. Disponível em: $<$ http://www.planalto.gov.br/ccivil_03/_ato2007-2010/2009/lei/112187.htm>. Acesso em: 31 março 2014.

16 BRASIL. Lei $\mathrm{n}^{\mathrm{o}} 12.305$, de 2 de agosto de 2010. Disponível em: $<$ http://www.planalto.gov.br/ccivil_03/_ato2007-2010/2010/lei/112305.htm>. Acesso em: 31 março 2014.

17 BRASIL. Lei $\mathrm{n}^{\mathrm{o}} 12 . \overline{5} 12$, de 14 de outubro de 2011. Disponível em: <http://www.planalto.gov.br/ccivil_03/_ato2011-2014/2011/Lei/L12512.htm>. Acesso: em 31 março 2014.

18 BRASIL. Lei $\mathrm{n}^{\mathrm{o}} 12.651$, de 25 de maio de 2012. Disponível em: <http://www.planalto.gov.br/ccivil_03/_ato2011-2014/2012/lei/112651.htm>. Acesso em: 31 março 2014.

19 BRASIL. Lei $\mathrm{n}^{\mathrm{o}} 12.854$, de 26 de agosto de 2013. Disponível em: $<$ http://www.planalto.gov.br/ccivil_03/_Ato2011-2014/2013/Lei/L12854.htm>. Acesso em: 31 março 2014.

${ }_{20}$ BRASIL. Lei $\mathrm{n}^{\mathrm{o}} 12.512$, de 14 de outubro de 2011. Disponível em: <http://www.planalto.gov.br/ccivil_03/_ato2011-2014/2011/Lei/L12512.htm>. Acesso: em 31 março 2014. 
possibilidade de serem constituídos direitos sobre os recursos genéticos (propriedade intelectual), como forma de equilibrar a relação entre os países detentores de biotecnologia e os países detentores de biodiversidade e (ii) a Convenção Quadro das Nações Unidas sobre Mudança do Clima ${ }^{22}$, que, por meio do Protocolo de Quioto ${ }^{23}$ (assinado em 1997), previu mecanismos de mercado que possibilitaram o aferimento de renda para aqueles que reduzissem as emissões de gases causadores de efeito estufa.

Por todo o exposto, observam-se iniciativas no Direito doméstico e no Direito Ambiental Internacional no sentido de prever incentivos ambientais para a proteção do meio ambiente. É preciso aprofundar no tema e fortalecer os instrumentos voltados a essa finalidade.

\footnotetext{
${ }^{21}$ Disponível em: <http://www.mma.gov.br/biodiversidade/convencao-da-diversidade-biologica>. Acesso em: 31 março 2014.

${ }^{22}$ Disponível em: <http://www.mma.gov.br/clima/convencao-das-nacoes-unidas>. Acesso em: 31 março 2014.

${ }^{23}$ Disponível em: <http://www.mma.gov.br/clima/protocolo-de-quioto>. Acesso em: 31 março 2014.
} 


\section{METODOLOGIA}

A presente Dissertação será guiada predominantemente pela análise da legislação em vigor, projetos de lei, doutrina e jurisprudência brasileiras e estrangeiras. Envolverá tanto a pesquisa teórica do tema proposto quanto o exame empírico de viés qualitativo, elegendo-se como paradigma comparativo a realidade. Haverá uma intersecção entre a gestão de políticas públicas, os instrumentos jurídicos de proteção ambiental e os aspectos econômicos. Isso tudo para o atendimento do fim maior do Direito Ambiental: a proteção do meio ambiente.

A pesquisa teórica compreenderá consulta de fontes primárias, sendo estas leis e regulamentos; bem como fontes secundárias, como bases doutrinárias em geral (livros, artigos e periódicos), acerca dos casos já existentes e dos projetos de concessão de incentivos ambientais.

Já a pesquisa empírica terá como principal objetivo analisar a percepção de atores envolvidos em experiências em que tenha havido a concessão de incentivos ambientais, como professores universitários, advogados, economistas etc., quanto aos obstáculos apontados nas hipóteses no item anterior.

Serão considerados, também, os dados obtidos no trabalho desenvolvido como consultor do instituto "O Direito por um Planeta Verde", no Estado de São Paulo, envolvendo reuniões com os órgãos públicos estaduais, visitas a comunidades e análise de doutrina sobre pagamento por serviços ambientais. 


\section{CAPÍTULO 1 - O DIREITO POSITIVO E AS NORMAS JURÍDICAS}

Este capítulo trata do Direito Positivo, do conceito de norma jurídica e da sua eficácia. Serão discutidos a positivação do Direito, os tipos de normas, a evolução dos ordenamentos jurídicos e a adequação das normas negativas e positivas no Direito Ambiental.

\subsection{O Direito positivo}

Tercio Sampaio Ferraz Júnior ensina que, até o Renascimento, o Direito possuía caráter sagrado ${ }^{24}$. Progressivamente, observa-se a dessacralização do Direito e, consequentemente, a tecnização do saber jurídico e a perda de seu caráter ético ${ }^{25}$.

O autor relata que o período compreendido entre 1600 e 1800 caracterizou-se pela influência dos sistemas racionais na teoria jurídica, pelo qual a exegese jurídica tornou-se mais artificial e mais livre. Pouco a pouco, abriram-se as portas para a entrada da ciência moderna na teoria jurídica ${ }^{26}$.

O Direito escrito, positivado, fortaleceu-se, em contraposição ao jusnaturalismo - cuja base é o Direito Natural - e ao Direito Consuetudinário - cuja base são os costumes. Neste sentido, Tercio Sampaio Ferraz Júnior aponta:

O fato de o Direito tornar-se escrito contribuiu para importantes transformações na concepção de direito e de seu conhecimento. A fixação do direito na forma escrita, ao mesmo tempo em que aumenta a segurança e a precisão de seu entendimento, aguça também a consciência dos limites. A possibilidade do confronto dos diversos conjuntos normativos cresce e, com isso, aumenta a disponibilidade das fontes, na qual está a essência do aparecimento das hierarquias. Estas, no início, ainda afirmam a relevância do costume, do direito não escrito sobre o escrito. Pouco a pouco, no entanto, a situação inverte-se ${ }^{27}$.

\footnotetext{
${ }^{24}$ FERRAZ JUNIOR, Tercio Sampaio. Introdução ao estudo do direito: técnica, decisão, dominação. São Paulo: Atlas, 2003, p. 65.

${ }^{25}$ Idem, ibidem.

${ }^{26}$ Idem, p. 66.

${ }^{27}$ Idem, p. 66-67.
} 
O autor ainda explica que há um sentido filosófico e um sentido sociológico na positivação do Direito.

No primeiro, a positivação designa o ato de positivar, isto é, de estabelecer um direito por força de um ato de vontade. Segue daí a tese segundo a qual o Direito é um conjunto de normas que valem por força de serem postas pela autoridade constituída portanto, ato de vontade da autoridade - e só por força de outra proposição podem ser revogadas. Com isso, à medida que tais atos de vontade são atos decisórios, positivação passa a ser termo correlato de decisão ${ }^{28}$.

No sentido sociológico, Tercio Sampaio Ferraz Júnior ensina que positivação é um fenômeno que será representado pela crescente importância da lei votada pelos parlamentos como fonte do Direito. A crítica dos pensadores iluministas e a necessidade de segurança da sociedade burguesa passou a exigir a valorização dos preceitos legais no julgamento dos fatos, de forma a evitar a dependência política que se projetava no arbítrio das decisões do Poder Judiciário ${ }^{29}$.

Nas palavras de Paulo de Barros Carvalho, o Direito Positivo pode ser definido como

\footnotetext{
${ }^{28}$ Idem, p. 74. O autor complementa: "Em consequência, implicando toda decisão a existência de motivos decisórios, positivação passa a ser um fenômeno em que todas as valorações, regras e expectativas de comportamento na sociedade têm de ser filtradas através de processos decisórios antes de adquirir validade jurídica (...). Em outras palavras, direito positivo é não só aquele que é posto por decisão, mas, além disso, aquele cujas premissas da decisão que o põem também são postas por decisão. A tese de que só existe um direito, o positivo nos termos expostos, é o fundamento do chamado positivismo jurídico, corrente dominante, em vários matizes, no século XIX".

${ }^{29}$ Idem, p. 74-75. O autor complementa: "Daí se originou um respeito quase mítico pela lei, base, então, para o desenvolvimento da poderosa Escola da Exegese, de grande influência nos países em que dominou o espírito napoleônico. A redução do jurídico ao legal foi crescendo durante o século XIX, até culminar no chamado legalismo. Não foi apenas uma exigência política, mas também econômica. Afinal, com a Revolução Industrial, a velocidade das transformações tecnológicas aumenta, reclamando respostas mais prontas do direito, que o direito costumeiro não podia fornecer. Ao contrário, o direito reduzido ao legal fazia crescer a disponibilidade temporal sobre o direito, cuja validade foi sendo percebida como algo maleável e, ao fim, manipulável, podendo ser tecnicamente limitada e controlada no tempo, adaptada a prováveis necessidades futuras de revisão, possibilitando, assim, em alto grau, um detalhamento dos comportamentos como juridicizáveis, não dependendo mais o caráter jurídico das condutas de algo que tivesse sempre sido direito (como acontecia com a predominância do direito consuetudinário)".
} 
camada de linguagem prescritiva que se projeta sobre a região material das condutas intersubjetivas para discipliná-las e orientá-las na direção de certos valores que a sociedade quer ver implantados ${ }^{30}$.

Independentemente da corrente que se adote, é fato que a positivação do Direito permitiu a evolução da sociedade, alicerçada na norma jurídica.

\subsection{A norma jurídica}

O conceito de norma jurídica já foi objeto de infindáveis estudos dos mais renomados doutrinadores do Direito. O tema insere-se na filosofia jurídica e leva os estudiosos a indagações infinitas sobre pressuposições, sua natureza de comando ou direção, os elementos de sua composição etc.

Tercio Sampaio Ferraz Junior ${ }^{31}$ aponta que a norma jurídica pode ser enfocada de três maneiras diferentes, conforme a corrente que se adote.

Em uma primeira corrente, os juristas consideram a norma como uma proposição, independentemente de quem a estabeleça ou para quem ela é dirigida. Tratase de uma proposição que diz como deve ser o comportamento, isto é, uma proposição de dever-ser. Promulgada a norma, ela passa a ter vida própria, conforme o sistema de normas no qual está inserida.

Um segundo grupo de juristas concebe a norma como uma prescrição, isto é, como atos de uma vontade que estabelece disciplina para a conduta. Essa corrente também entende que a norma se expressa pelo dever-ser, que significa, então, impositivo ou impositivo de vontade. As normas são, portanto, imperativos ou comandos de uma vontade institucionalizada, isto é, apta a comandar.

\footnotetext{
${ }^{30}$ Princípios e sobreprincípios na interpretação do direito. In: DE LUCCA, Newton; MEYER-PFLUG, Samantha Ribeiro; NEVES, Mariana Barboza (Coord.). Direito constitucional contemporâneo. São Paulo: Quartier Latin, 2012, p. 281.

${ }^{31}$ FERRAZ JUNIOR, Tercio Sampaio. Op. cit., p. 100.
} 
Por fim, uma terceira visão sobre o conceito de norma jurídica a considera como um fenômeno complexo que envolve não só a vontade de seu comando, mas também diferentes situações estabelecidas entre as partes que se comunicam. Nesse caso, a norma é vista como comunicação, ou seja, troca de mensagens entre seres humanos, na forma de subordinação ou coordenação.

Para a análise da norma como comunicação, como ressalta o autor,

torna-se importante não só a mensagem (proposição), não só as qualidades do prescritor, mas também a identificação dos sujeitos, seu modo de reação às prescrições, sua própria qualificação como sujeito ${ }^{32}$.

Como se vê, independentemente da visão que se adote, a norma jurídica é critério fundamental de análise da sociedade e seus conflitos, refletindo um dever-ser da conduta, um conjunto de proibições, obrigações, permissões, por meio do qual os homens criam entre si relações de subordinação, coordenação, organizam seu comportamento coletivamente, interpretam suas próprias prescrições, delimitam o exercício do poder, estimulam o rumo de sua sociedade e economia etc.

A norma pode ser negativa (proibição) ou positiva (comando). As proibições ou comandos podem vir acompanhados de incentivos (sanção positiva) ou de punições (sanções negativas) ${ }^{33}$. Ou seja, nem toda norma negativa utiliza-se de penalidades e nem toda norma positiva vale-se de incentivos. Existem, portanto, quatro situações possíveis: (i) comandos reforçados por prêmios; (ii) comandos reforçados por castigos; (iii) proibições reforçadas por prêmios e (iv) proibições reforçadas por castigos.

Uma pequena dificuldade ocorre quando os comandos ou proibições referem-se a omissões em vez de ações. Quanto ao tema, Norberto Bobbio anota:

(...) existe uma tendência de premiar ou punir uma ação mais do que uma omissão - mas uma ação ou é o comportamento conforme a um comando, ou é o comportamento não conforme a uma proibição. Em outras palavras, é mais fácil premiar uma ação do que uma omissão - mas, então, aquilo que é premiado é um comportamento previsto por uma norma positiva. É mais fácil

\footnotetext{
${ }^{32}$ Idem, p. 101.

${ }^{33}$ Esses temas serão tratados detalhadamente nos Capítulos 3 e 4.
} 
punir uma ação do que uma omissão - mas, então, aquilo que se pune é um comportamento contrário a uma proibição ${ }^{34}$.

$\mathrm{O}$ ordenamento jurídico pode se voltar a normas protetivo-repressivas ou a normas promocionais, sejam elas de caráter positivo ou negativo. No primeiro caso, existem três modos típicos de impedir uma ação não desejada: torná-la impossível, tornála difícil ou torná-la desvantajosa. Por outro lado, o ordenamento promocional busca atingir os mesmos fins por três operações contrárias, isto é, buscando tornar a ação desejada necessária, fácil ou vantajosa.

Aplica-se a técnica do desencorajamento no sistema protetivo-repressivo e do encorajamento no sistema promocional. Por desencorajamento, entende-se a operação pela qual A procura influenciar o comportamento não desejado, comissivo ou omissivo, de B, ou obstaculizando-o ou atribuindo-lhe consequências desagradáveis. Simetricamente, por encorajamento, tenha-se a operação pela qual A procura influenciar o comportamento desejado, comissivo ou omissivo, de B, facilitando-o ou atribuindo-lhe consequências agradáveis.

Daí nota-se que a atuação do ordenamento jurídico pode ser prévia ou posterior à conduta. Previamente, pode-se facilitar ou obstaculizar; posteriormente, pode-se atribuir consequências agradáveis ou desagradáveis, ao que se denomina sanção. Tal ponto é importante para diferenciar o entendimento clássico de que apenas a sanção, seja positiva ou negativa, é instrumento válido para induzir comportamentos.

As técnicas de encorajamento e desencorajamento agem nos comportamentos já realizados e naqueles que ainda virão ou estão desenvolvendo-se. Enquanto medida prévia, estabelecem uma ameaça, a título de desencorajamento; ou uma promessa, a título de encorajamento. Como ameaça, além de induzir determinados comportamentos, buscam a conservação social, a inércia; por outro lado, como promessa, buscam a mudança, a alteração. Quando tendem a promover o comportamento desejado, suscitam uma esperança; quando buscam impedir o comportamento não desejado, provocam um temor.

\footnotetext{
${ }^{34}$ BOBBIO, Norberto. Op. cit., p. 6.
} 
Por outro lado, técnicas de desencorajamento ou encorajamento, quando aplicadas em condutas já realizadas, encaixam-se como uma reação do Estado que pode ser favorável, quando o comportamento é desejado; ou desfavorável, quando o comportamento é indesejado.

A aplicação de técnicas de encorajamento em momento prévio recebeu da doutrina de Norberto Bobbio a denominação de "técnica da facilitação",35. Isso porque, em vez de se estabelecer uma compensação ou recompensa por uma atitude benéfica, buscou-se facilitar ou tornar menos penosa a realização de determinada atividade. Notese a diferença: a recompensa vem depois, enquanto a facilitação precede ou acompanha a ação que se pretende encorajar.

Transpondo a teoria para o Direito Ambiental, é possível recompensar aquele proprietário que recupera ou mantém vegetação nativa em sua propriedade, da mesma forma que todo o processo de recuperação e de manutenção poderia ter sido facilitado ou encorajado.

Por fim, as técnicas de desencorajamento ou encorajamento podem ser classificadas em diretas ou indiretas. São diretas aquelas que procuram suscitar o comportamento desejado ou impedir o indesejado agindo diretamente sobre $\mathrm{o}$ comportamento em si, como é o caso das operações de fiscalização dos órgãos ambientais. Tratam-se de medidas de controle ou de vigilância.

Nas técnicas indiretas, o comportamento não desejado ou desejado continua sendo possível, mas torna-se mais difícil ou mais fácil; ou, uma vez que tenha sido praticado, é seguido por medidas que pretendem a sua retribuição ou reparação.

A título de exemplo, se o órgão ambiental exige, mediante notificação ou condicionante técnica da licença ambiental, que seja feito o plantio de mil mudas de

\footnotetext{
${ }^{35}$ Idem, p. 30. Norberto Bobbio destaca: "Por técnica de facilitação, entendo o conjunto de expedientes com os quais um grupo social organizado exerce um determinado tipo de controle sobre os comportamentos de seus membros (neste caso, trata-se do controle que consiste em promover a atividade na direção desejada), não pelo estabelecimento de uma recompensa à ação desejada, depois que esta tenha sido realizada, mas atuando de modo que a sua realização se torne mais fácil ou menos difícil”.
} 
determinada espécie, exerce controle indireto. Se, por outro lado, faz visitas constantes na propriedade a fim de verificar o plantio, exerce controle direto.

\title{
1.3 A evolução do Estado e das normas jurídicas
}

\author{
Como anota Norberto Bobbio,
}

o papel do direito na sociedade é comumente considerado do ponto de vista da sua função predominante, que sempre foi aquela, mais passiva que ativa, de proteger determinados interesses mediante a repressão dos atos desviantes ${ }^{36}$.

Norberto Bobbio ensina, no prefácio à edição brasileira da obra "Da estrutura à função: novos estudos de teoria do direito", que o Estado deixou sua função "garantista" e passou a desenvolver papel "dirigista", encontrando no Direito uma ferramenta de controle social, no sentido estrito da palavra, para o fim de direção social. Segundo o autor italiano, o Direito é capaz de direcionar a sociedade pelo uso de sanções positivas, preferindo utilizar o termo genérico incentivos,

\footnotetext{
os quais visam não a impedir atos socialmente indesejáveis, fim precípuo das penas, multas, indenizações, reparações, restituições, ressarcimentos etc., mas sim, a 'promover' a realização de atos socialmente desejáveis ${ }^{37}$.
}

As sanções positivas, portanto, ganham espaço no espírito assistencialista do Estado contemporâneo, quando o Direito não mais se limita a tutelar atos que estão em conformidade com o ordenamento jurídico, tendendo a estimular atos inovadores. A função estatal deixa de ser exclusivamente protetora e repressiva, passando a assumir papel também promocional. Com isso, paralelamente ao emprego quase exclusivo das sanções negativas - as quais constituem técnica de repressão, por excelência - passam a empregar sanções positivas, que darão estímulo e propulsão a atos considerados benéficos à sociedade.

\footnotetext{
${ }^{36}$ Idem, p. 24.

${ }^{37}$ Idem, p. XII.
} 
Para ele, essa função não é nova, mas é nova a extensão que teve e continua a ter no Estado contemporâneo ${ }^{38}$, a ponto de fazer parecer completamente inadequada e lacunosa uma teoria do Direito que continua a considerar o ordenamento jurídico do ponto de vista de sua função tradicional puramente protetora e repressiva. O Direito não deve se prender à imagem simplista do Estado como organismo que estabelece as regras do jogo e define um árbitro, um organismo com técnicas limitadas, perseguindo fins igualmente limitados.

Celso Lafer, em seu prefácio à supracitada obra de Norberto Bobbio, aponta que, na medida em que o Direito não se limita ao permitir e ao proibir, mas almeja o promover, é preciso levar em conta a dimensão positiva das sanções, que assume a forma de incentivos e prêmios. Segundo Celso Lafer:

(...) estas são as duas formas típicas por meio das quais se manifesta, no direito positivo, a função promocional do direito voltada para impulsionar e para sustentar condutas. Daí a instigante contribuição dada por ele ao tema por meio da discussão das sanções premiais que são compensações previstas pelo Direito para se alcançar uma direção social de conduta ${ }^{39}$.

As ações do Estado atual são e devem ser cada vez mais diferentes do Estado liberal clássico: dá-se preferência a técnicas de encorajamento em acréscimo, ou em substituição, às técnicas tradicionais de desencorajamento.

Não se ignora o fato de que essa inovação coloca em cheque boa parte das teorias tradicionais do Direito, em que se limita a classificar a ciência jurídica como conjunto de normas de proteção ou repressão. Para tais teorias, poder-se-ia dizer, em poucas palavras, que o Direito desenvolve função de proteção aos atos lícitos (entendidos como permitidos ou obrigatórios) e de repressão de atos ilícitos (entendidos como contrários à lei).

\footnotetext{
${ }^{38}$ Idem, p. 89. Norberto Bobbio aponta: "Nas sociedades tecnicamente avançadas, são dignas de nota pelo menos duas tendências capazes de suscitar algumas reflexões úteis sobre a perda de função do direito, e, pretendo dizer, do direito naquela de suas funções que sempre lhe foi atribuída, a ponto de ser amiúde considerada como a única e exclusiva, a função repressiva. Essas duas tendências são: a ampliada potência dos meios de socialização e, em geral, de condicionamento do comportamento coletivo por meio das comunicações de massa, e o previsível aumento dos meios de prevenção social em relação aos meios tradicionais de repressão (...). Podemos levantar a hipótese de que, à medida que aumenta a potência dos meios de condicionamento psicológico, dos meios do consenso (não importa se manipulado), diminui a necessidade dos meios coercitivos, isto é, do direito".

${ }^{39}$ Idem, p. LIII.
} 
Quanto ao tema, Norberto Bobbio aponta Christianus Thomasius, segundo o qual "o direito se caracteriza por conquistar o próprio objetivo (que é essencialmente protetor) por meio da emanação de comandos negativos (proibições)" ${ }^{\text {"40 }}$.

E, continua, ensinando que

Thomasius considerou o direito como um conjunto de normas negativas (que, afinal, se resumiam substancialmente no preceito neminem laedere), a fim de oferecer um critério simples e claro que servisse para distinguir as normas jurídicas de outras normas, como as da moral individual e as da moral social ${ }^{41}$.

É o que se entende pela busca da ordem pública, matéria essencialmente tratada pelo Direito Penal.

Uma das principais características do Direito Penal, vale notar, é o uso de normas negativas, pelas quais criam-se proibições e penalidades aplicáveis quando do descumprimento. Para tanto, como se sabe, faz-se uso de todo um aparato policial e militar.

Curioso notar que, embora a alavanca da manutenção da ordem pública seja a pena, o mesmo não ocorre quando o objetivo é a busca da ordem econômica. Veja-se, como exemplo, a fixação de juros básicos pelo Comitê de Política Monetária $\left(\mathrm{COPOM}^{42}\right)$ do Banco Central do Brasil, para fins de estímulo, desestímulo e atendimento de metas de controle de inflação no mercado brasileiro ${ }^{43}$.

Como ensina Norberto Bobbio,

\footnotetext{
${ }^{40}$ Idem, p. 2.

${ }^{41}$ Idem, p. 3.

${ }^{42}$ Disponível em: <http://www.bcb.gov.br/?COPOMHIST>. Acesso em: 31 março 2014.

43 A Constituição Brasileira estabelece, no artigo 192, que o sistema financeiro nacional deve ser estruturado para promover o desenvolvimento equilibrado do País. Daí se nota que a estratégia não é de repressão, mas de promoção. In verbis: "Art. 192. O sistema financeiro nacional, estruturado de forma a promover o desenvolvimento equilibrado do País e a servir aos interesses da coletividade, em todas as partes que o compõem, abrangendo as cooperativas de crédito, será regulado por leis complementares que disporão, inclusive, sobre a participação do capital estrangeiro nas instituições que o integram" (BRASIL. Constituição Federal (1988).

Disponível

em $<$ http://www.planalto.gov.br/ccivil_03/constituicao/constituicao.htm>. Acesso em: 31 março 2014).
} 
Os atos humanos podem distinguir-se em atos conformes e atos desviantes. Pois bem, em relação aos atos conformes, a técnica do desencorajamento visa proteger o seu exercício, tutelando a possibilidade de fazer ou não fazer, caso se trate de atos permitidos, a possibilidade de fazer, caso se trate de atos obrigatórios, e a possibilidade de não fazer, caso se trate de atos proibidos. Em relação aos atos desviantes, a técnica do desencorajamento tem por alvo, atribuindo-lhes determinadas consequências, apenas os atos desviantes por defeito, os atos propriamente não-conformes, e limita-se a tolerar - não lhes atribuindo qualquer efeito jurídico - os atos desviantes por excesso, isto é, os atos superconformes (as chamadas ações super-rogatórias) ${ }^{44}$.

A técnica do encorajamento visa a não apenas tutelar, mas também a provocar o exercício dos atos conformes, desequilibrando, no caso de atos permitidos, a possibilidade de fazer e a possibilidade de não fazer, tornando os atos obrigatórios particularmente atraentes e os atos proibidos particularmente repugnantes.

Voltando à questão do ordenamento jurídico protetivo-repressivo e do ordenamento promocional, é possível dizer que, ao primeiro, interessam, sobretudo, os comportamentos socialmente não desejados, sendo seu fim precípuo impedir o máximo possível a sua prática.

Neste raciocínio, vale destacar a doutrina de Kelsen, quando afirma que apenas se deve considerar como juridicamente prescrita - ou, o que é o mesmo,
como conteúdo de um dever jurídico - uma certa conduta, quando a conduta
oposta seja normada como pressuposto de um ato coercitivo que é dirigido
contra os indivíduos que por tal forma se conduzam ${ }^{45}$.

No ordenamento promocional, interessam, principalmente, os comportamentos socialmente desejáveis, sendo seu fim levar a realização destes até mesmo aos mais resistentes. Ou seja, a técnica do encorajamento reflete uma verdadeira transformação na função do sistema normativo em seu todo e no modo de realizar o controle social. Além disso, desvia o foco do sistema, mais preocupado em desfavorecer ações nocivas, para que ações vantajosas sejam favorecidas.

\footnotetext{
${ }^{44}$ BOBBIO, Norberto. Op. cit., p. 14-15.

${ }^{45}$ KELSEN, Hans. Teoria pura do direito. São Paulo: Martins Fontes, 2000, p. 56.
} 
Como observa a doutrina, os textos constitucionais contemporâneos apontam a função do Estado de proteger e de reprimir, mas também trazem dispositivos relacionados à sua função promocional.

A Constituição brasileira não seguiu outro caminho e trouxe inúmeros dispositivos em que o Estado assume função de promover, orientar e incentivar. Em seu artigo $3^{\circ}$, inciso $\mathrm{IV}^{46}$, o texto constitucional brasileiro estabelece como um dos objetivos fundamentais da República Federativa do Brasil promover o bem de todos, sem preconceitos de origem, raça, sexo, cor, idade e quaisquer outras formas de discriminação.

No artigo $5^{\circ}$, inciso $\mathrm{XXXII}^{47}$, menciona-se o dever do Estado de promover a defesa do consumidor. Prevê-se, também, como dever dos Municípios, promover o adequado ordenamento territorial, mediante planejamento e controle do uso, do parcelamento e da ocupação do solo urbano (artigo 30, inciso VIII ${ }^{48}$ ). Por fim, a Constituição brasileira estabelece como dever do Presidente e do Vice-Presidente promover o bem geral do povo brasileiro (artigo $78^{49}$ ). São mescladas, portanto, medidas protetivas, garantidoras e repressoras com medidas de promoção ou de incentivo.

\footnotetext{
46 "Art. $3^{\circ}$ Constituem objetivos fundamentais da República Federativa do Brasil: (...) IV - promover o bem de todos, sem preconceitos de origem, raça, sexo, cor, idade e quaisquer outras formas de discriminação" (BRASIL. Constituição $\quad$ Federal (1988). Disponível em <http://www.planalto.gov.br/ccivil_03/constituicao/constituicao.htm>. Acesso em: 31 março 2014).

47 "Art. $5^{\circ}$ Todos são iguais perante a lei, sem distinção de qualquer natureza, garantindo-se aos brasileiros e aos estrangeiros residentes no País a inviolabilidade do direito à vida, à liberdade, à igualdade, à segurança e à propriedade, nos termos seguintes: (...) XXXII - o Estado promoverá, na forma da lei, a defesa do consumidor (...)" (BRASIL. Constituição Federal (1988). Disponível em $<$ http://www.planalto.gov.br/ccivil_03/constituicao/constituicao.htm>. Acesso em: 31 março 2014).

48 "Art. 30. Compete aos Municípios: (...) VIII - promover, no que couber, adequado ordenamento territorial, mediante planejamento e controle do uso, do parcelamento e da ocupação do solo urbano (...)" (BRASIL. Constituição $\quad$ Federal (1988). Disponível em $<$ http://www.planalto.gov.br/ccivil_03/constituicao/constituicao.htm>. Acesso em: 31 março 2014).

49 “Art. 78. O Presidente e o Vice-Presidente da República tomarão posse em sessão do Congresso Nacional, prestando o compromisso de manter, defender e cumprir a Constituição, observar as leis, promover o bem geral do povo brasileiro, sustentar a união, a integridade e a independência do Brasil" (BRASIL. Constituição $\quad$ Federal (1988). $\quad$ Disponível em $<$ http://www.planalto.gov.br/ccivil_03/constituicao/constituicao.htm>. Acesso em: 31 março 2014).
} 
A doutrina, ainda, chama atenção para o uso de diferentes instrumentos pelo Estado, seja para fins promocionais, seja para fins de repressão. Quanto ao ponto, Ana Maria de Oliveira Nusdeo cita os instrumentos de comando e controle e os instrumentos econômicos ${ }^{50}$.

Para ela, instrumentos de comando e controle caracterizam-se por

fixar normas, regras, procedimentos e padrões determinados para as atividades econômicas a fim de assegurar o cumprimento dos objetivos da política em questão, por exemplo, reduzir a poluição do ar ou da água ${ }^{51}$.

Em contraposição, os instrumentos econômicos têm

caráter indutor dos comportamentos desejados pela política ambiental, valendo-se de meios como a imposição de tributos e preços públicos, a criação de subsídios ou ainda a possibilidade de transação sobre direitos de emissão de substância ou de créditos obtidos pela não poluição ${ }^{52}$.

Ana Maria de Oliveira Nusdeo ainda destaca que, embora fundamentais em qualquer política ambiental, os instrumentos de comando e controle são considerados insuficientes para a criação de incentivos específicos para práticas de conservação, desenvolvimento de novas tecnologias e correção de preços de produtos e serviços impactantes ao meio ambiente ${ }^{53}$.

O autor norte-americano Richard Stewart aponta que o sistema de comando e controle estabelece uma regulação que exige ações específicas de uma entidade reguladora, normalmente mediante a definição de padrões tecnológicos de poluição ou segurança $\mathrm{a}^{54}$.

\footnotetext{
${ }^{50}$ NUSDEO, Ana Maria de Oliveira. Pagamento por Serviços Ambientais: sustentabilidade e disciplina jurídica. São Paulo: Atlas, 2012, p. 2.

${ }^{51}$ Idem, Ibidem.

${ }^{52}$ Idem, Ibidem.

${ }^{53}$ Idem, p. 3.

${ }^{54}$ BREGER, Marshall J.; ELLIOTT, E. Donald; HAWKINS, David; STEWART, Richard R. Providing economic incentives in environmental regulation. Faculty Scholarship Series. Paper 2206, 1991, p. 468. Disponível em:

$<$ http://digitalcommons.law.yale.edu/cgi/viewcontent.cgi?article=3198\&context=fss_paper $>$. Acesso em: 31 março 2014.
} 
Outro autor norte-americano, Myrick Freeman III, destaca que o sistema de comando e controle envolve a definição de padrões e limites para cada fonte de poluição, o que deve ser acompanhado de um sistema de monitoramento do cumprimento das obrigações e definição de penalidades para os infratores ${ }^{55}$.

Na opinião de Richard Stewart, a proliferação de medidas de comando e controle não é o caminho mais adequado e funcional, a longo prazo, de lidar com as questões ambientais, pois trata-se de uma opção cara e com imperfeições ${ }^{56}$. Todavia, segundo o autor, é o mecanismo mais utilizado na maior parte dos sistemas jurídicos, motivo pelo qual tornou-se uma tradição.

É aplicado para o controle de atividades industriais, consumo de medicamentos e drogas, transporte de cargas, controle de emissões etc ${ }^{57}$. O mecanismo confere, ainda, um poder estratégico, para as autoridades públicas, de interferir nas atividades econômicas, o que significa que a sua substituição por outros mecanismos torna-se desinteressante para tais autoridades ${ }^{58}$.

\footnotetext{
${ }^{55}$ FREEMAN III, A. Myrick. Op. cit., p. 197. Quanto ao tema, observa: "The major provisions of the federal laws controlling air and water pollution embody what is often termed a direct regulation (or command and control) approach to achieve the established pollution control targets. This direct regulation approach involves placing limits on the allowable discharges of polluting substances from each source, coupled with an administrative and legal system to monitor compliance with these limits and to impose sanctions or penalties for violations".

${ }^{56}$ BREGER, Marshall J.; ELLIOTT, E. Donald; HAWKINS, David; STEWART, Richard R. Op. cit., p. 468.

${ }^{57}$ STEWART, Richard B. Economic incentives for environmental protection: Opportunities and obstacles. In: REVESZ, Richard; SANDS, Philippe; STEWART, Richard B. (Editors). Environmental law, the economy, and sustainable development: the United States, the European Union, and the international community. New York: Cambridge University Press, 2000. p. 200. Quanto ao tema, o autor explica: "Notwithstanding the advantages of EIS [economic incentive system] in addressing many environmental problems, environmental regulatory programs in most jurisdictions, including the US and the EU and under international environmental agreements, have relied almost entirely on command-and-control instruments. This pattern reflects tradition. Command measures have been the dominant regulatory instrument used to address other problems of industrialization, including unsafe and ineffective drugs, market power in sectors of the economy such as transportation and financial services, and unsafe vehicles and workplaces. Command regulation has a simple and appealing logic: people should be made to stop doing something bad. Command regulation promises effective control of behavior. Command environmental regulation has been successful in reducing substantially discharges of some air and water pollutants and preventing potentially large increases in others. It has also made significant progress in controlling hazardous wastes. Although crude and costly, the command system for environmental regulation has 'worked',".

${ }^{58}$ Idem, ibidem.
} 

destacam:

\begin{abstract}
Nos últimos anos, tem aumentado o interesse pelas possibilidades de aplicação de instrumentos econômicos como forma de mitigar o uso predatório dos recursos naturais e fomentar sua proteção e o seu uso sustentável. Tal interesse se deve à constatação de que a utilização dos instrumentos de "Comando e Controle", de forma isolada, revelou-se insuficiente para assegurar os resultados esperados das políticas ambientais, em particular no que diz respeito ao uso dos recursos florestais. De forma semelhante, tem ganhado força a ideia de que as políticas ambientais precisam se articular às dimensões econômica $\mathrm{e}$ social do processo de desenvolvimento ${ }^{59}$.
\end{abstract}

Muitas vezes, o custo de seguir determinada regra é tão caro que acaba sendo menos custoso descumpri-la e, na hipótese de uma autuação pelas autoridades, combater administrativa e judicialmente todas as exigências ou sanções que possam ter sido impostas. Note-se que, havendo descumprimento da regra e discussão processual quanto às exigências e sanções, o meio ambiente restará desprotegido e as autoridades públicas estarão obrigadas a aguardar o trâmite de tais processos ${ }^{60}$.

Além disso, é preciso considerar que o sistema de comando e controle nada faz para aquele que se mantém abaixo dos padrões permitidos de poluição, de forma que este preferirá chegar próximo aos níveis permitidos. Seria interessante se tivesse vantagens por estar abaixo dos níveis permitidos.

Como alternativa, Ana Maria de Oliveira Nusdeo $^{61}$ propõe a discussão da inclusão de instrumentos econômicos, de caráter indutivo, nas políticas ambientais. Esses têm, como uma de suas características, maior eficiência em comparação aos de comando e controle, no sentido de permitir a consecução dos objetivos da política ambiental por meio das medidas de menor custo aos seus destinatários e à própria administração pública.

\footnotetext{
59 MAY, Peter H.; AMARAL, Carlos; MILliKAN, Brent; ASCHER, Petra (Orgs.). Instrumentos econômicos para o desenvolvimento sustentável da Amazônia brasileira. Brasília: Ministério do Meio Ambiente, 2005. Disponível em:

$<$ http://www.mma.gov.br/estruturas/168/_publicacao/168_publicacao30012009115059.pdf $>$. Acesso em: 31 março 2014.

${ }^{60}$ BREGER, Marshall J.; ELLIOTT, E. Donald; HAWKINS, David; STEWART, Richard R. Op. cit., p. 468.

${ }^{61}$ NUSDEO, Ana Maria de Oliveira. Pagamento por serviços ambientais... cit., p. 3.
} 


\section{Por sua vez, Werner Grau Neto propõe}

a adoção de sistemas adicionais, fundados na mecânica de incentivos e desestímulos, marcados pelo conceito das exclusões, salvaguardas e induções, como mecanismo de indução do mercado ao exercício de atividades sustentáveis, em detrimento das atividades menos adequadas ao mote da sustentabilidade $^{62}$.

\section{Quanto ao assunto, Terence Dorneles Trennepohl afirma:}

Pode-se mencionar três mecanismos de proteção ambiental utilizado pelo Estado: a) sanções penais; b) as medidas administrativas; e, c) os instrumentos econômicos ${ }^{63}$.

E continua, apontando que

o primeiro deles está em flagrante decadência, pois os elementos de que o Estado dispõe para aplicação de sanções encontra resistência nos novos paradigmas de modernidade, resultando a legislação de punição aos crimes ambientais, como a Lei de Crimes Ambientais (Lei nº 9.605/1998), muito mais simbólica que efetiva, razão da infinidade de meios de defesa individual e do redirecionamento das penas para a figura da pessoa jurídica, desembocando, no mais das vezes, nas penalidades administrativas. O segundo deles, as medidas administrativas, são geralmente representadas pela repressão e pelas práticas de cunho ordenatório ${ }^{64}$.

E, conclui, ressaltando que os instrumentos econômicos influenciam na adoção de políticas de incentivos, mormente nos preços de bens e serviços, tornando mais atraente a opção ecologicamente mais desejável ${ }^{65}$.

Em geral, como já observado por muitos dos aplicadores do Direito, as normas de incentivo fiscal são mais aceitas e recebidas do que as sanções negativas, pois estão estatuídas sob os pilares da intervenção estatal no domínio econômico, por meio da extrafiscalidade, inerente à tributação moderna. São exemplos: isenções, imunidades, alíquotas zero ou reduzidas, redução da base de cálculo, bonificações, subsídios, subvenções etc.

\footnotetext{
${ }^{62}$ GRAU NETO, Werner. O novo paradigma indutor do trato tributário da questão ambiental: do poluidorpagador ao princípio da sustentabilidade. In: LECEY, Eladio Luiz da Silva; CAPPELLI, Silvia (Coords.) Revista de Direito Ambiental, n. 64. São Paulo: RT, 2011, p. 24.

${ }^{63}$ TRENNEPOHL, Terence Dorneles. Op. cit., p. 102.

${ }^{64}$ Idem, ibidem.

${ }^{65}$ Idem, ibidem.
} 
Forçoso observar, neste raciocínio, que o Estado não deve limitar-se a criar normas de comandos, proibições ou limites para atingir seus fins. É preciso garantir a felicidade, o bem estar e os bons costumes da população. Em outras palavras, o ordenamento jurídico não deve limitar-se à atuação protetivo-repressiva, mas assumir uma função promocional.

\subsection{A eficácia das normas jurídicas}

Como ensina Tercio Sampaio Ferraz Junior, a norma jurídica, para produzir seus efeitos, deve ser válida, estar vigente, ter eficácia e estar em vigor ${ }^{66}$.

Ensina que a norma será válida se integrada no ordenamento jurídico ${ }^{67}$. Assim, é preciso que o seu processo de formação ou produção normativa seja cumprido, em conformidade com os requisitos do próprio ordenamento, após o qual, a norma será válida.

Essa mesma norma será vigente se devidamente publicada, em cumprimento às regras específicas à sua natureza. Da mesma forma, terá vigor se for impositiva, se não houver impedimentos para subtrair o seu comando.

A característica da eficácia exige uma análise mais aprofundada e está relacionada aos resultados que a norma alcança na sociedade. Mesmo que válida e vigente, é possível que a norma não seja eficaz, ou seja, não produza efeitos.

Tercio Sampaio Ferraz Junior deixa claro que "vigência e eficácia são qualidades distintas. A primeira refere-se ao tempo de validade. A segunda, à produção de efeitos" $" 68$.

\footnotetext{
${ }^{66}$ FERRAZ JUNIOR, Tercio Sampaio. Op. cit., p. 197.

${ }^{67}$ Idem, ibidem.

${ }^{68}$ Idem, p. 199.
} 
A capacidade de produzir efeitos depende de requisitos fáticos e técnicos. A presença de requisitos fáticos torna a norma efetiva ou socialmente eficaz. Isso significa que a norma encontra, na realidade, as condições adequadas para produzir seus efeitos.

Assim, se uma norma torna obrigatório o uso de um equipamento ou de tecnologia para evitar danos ambientais, mas não há qualquer empresa capaz de fornecêlos no mercado, a norma será ineficaz. Como se percebe, não haverá interferência na validade ou na vigência da norma, mas tão somente nos efeitos que não produzirá na sociedade ${ }^{69}$.

Com relação aos requisitos técnicos, é necessário que a norma esteja devidamente correlacionada às demais normas do ordenamento, sem as quais não se pode produzir efeitos. Será ineficaz, por exemplo, a norma que exigir o cumprimento dos padrões de pressão sonora, mas que transfere à outra norma a definição desses padrões. Enquanto a segunda norma não existir, a primeira não produzirá efeitos.

Para Hans Kelsen, uma norma que não tem eficácia perde a validade. Afirma que

eficácia é condição no sentido de que uma ordem jurídica como um todo e uma norma jurídica singular já não são consideradas como válidas quando cessam de ser eficazes ${ }^{70}$.

\footnotetext{
${ }^{69}$ Idem, ibidem. Tercio Sampaio Ferraz Junior observa, quanto ao ponto, que a tese não é tranquila na doutrina, in verbis: "Realmente, poderíamos argumentar com um exemplo: uma norma que determinasse a convocação de um cidadão para compor a mesa de apuração de uma eleição, sem prever qualquer sanção para seu não-comparecimento, ocorrendo a ausência do convocado na data especificada, deveríamos dizer que aquela norma não terá tido e não mais poderia ter nenhuma efetividade, faltando-lhe o mínimo de que fala Kelsen; estaríamos, nesse caso, diante de norma estabelecida corretamente pela autoridade (válida) que, por aquela razão, não seria válida?; teria a autoridade editado validamente uma norma não válida? Cremos, destarte, que a ineficácia de uma norma, a ausência de um mínimo de efetividade, não afeta sua validade, pois a norma editada entrou para o ordenamento, ainda que nunca tivesse produzido efeitos. Por outro lado, a mesma doutrina reconhece que, se uma norma ficar sem observância e sem aplicação por longo tempo, entra em desuso, podendo-se falar na perda de seu sentido normativo: uma norma que proibisse o uso de camisas verdes no recinto da Câmara Municipal (decorrência da proscrição política do Integralismo, em 1937, que tinha a camisa verde como símbolo) e que nunca tivesse sido revogada, teria hoje ainda validade?".

${ }^{70}$ KELSEN, Hans. Op. cit., p. 236.
} 
Independentemente da corrente que se adote, o estudo da eficácia das normas é importante para se verificar quais os resultados que o ordenamento jurídico tem trazido para a sociedade. Tal como será demonstrado, o uso exclusivo de normas repressoras não traz resultados positivos, especialmente no campo do Direito Ambiental, motivo pelo qual as normas promocionais, cada vez mais, têm sido utilizadas pelo Estado contemporâneo. 


\section{CAPÍTULO 2 - A EVOLUÇÃO DO DIREITO AMBIENTAL NO BRASIL E A SUA FINALIDADE}

Este Capítulo destina-se a comentar a evolução do Direito Ambiental no Brasil, com o fim de demonstrar que, cada vez mais, o legislador brasileiro cria normas de estímulo e promoção da proteção ao meio ambiente. Trata, ainda, dos principais princípios que norteiam o grande escopo do Direito Ambiental: a proteção do meio ambiente.

Vladimir Passos de Freitas aponta que a legislação portuguesa, vigente no Brasil colônia, proibia o corte de árvores frutíferas; vedava a caça de perdizes, de lebres e de coelhos com redes, fios, ou outros meios ou instrumentos capazes de causar dor e sofrimento na morte desses animais; punia com multa quem jogasse material que sujasse rios ou viesse a matar peixes ${ }^{71}$.

Todavia, foram as Ordenações Manuelinas que trouxeram normas mais detalhadas sobre a proteção ao meio ambiente ${ }^{72}$. Segundo Georgette Nacarato Nazo e Toshio Mukai, as Ordenações Manuelinas introduziram um zoneamento ambiental, para que a caça fosse vedada em determinados lugares ${ }^{73}$.

\footnotetext{
${ }^{71}$ FREITAS, Gilberto Passos de. A Constituição Federal e a efetividade das normas ambientais. Tese (Doutorado em Direito). Faculdade de Direito da Universidade Federal do Paraná. Curitiba, 1998, p. 9. In verbis: "As Ordenações Afonsinas, no Livro V, Título LVIII, proibiam o corte de árvores frutíferas; o Livro V, Título LXXXIII, das Ordenações Manoelinas, vedava a caça de perdizes, lebres e coelhos com redes, fios, bois ou outros meios e instrumentos capazes de causar dor e sofrimento na morte desses animais; as Ordenações Filipinas protegiam as águas, no Livro LXXV, Título LXXXVIII, $\S 7^{\circ}$, punindo com multa quem jogasse material que sujasse ou viesse a matar os peixes".

${ }_{72}$ NAZO, Georgette Nacarato; MUKAI, Toshio. O direito ambiental no Brasil: evolução histórica e a relevância do direito internacional do meio ambiente. In: MILARÉ, Édis; MACHADO, Paulo Affonso Leme (Org.). Direito ambiental: direito ambiental internacional e temas atuais. São Paulo: RT, 2011. p. 1063.

${ }^{73}$ Idem, p. 1064.
} 
Teria sido 12.12.1605 a data em que a primeira lei de proteção florestal do Brasil foi criada, ficando conhecida como "Regimento do Pau-Brasil"," A partir de então, os autores apontam que foram editadas várias determinações reais sob a forma de leis, alvarás, cartas régias e regimentos ${ }^{75}$.

Ann Helen Wainer destaca que foi somente no período do Império, iniciado em 1808, que as normas brasileiras de cunho ambiental passaram a reconhecer a teoria da reparação do dano ecológico ${ }^{76}$. Ainda destaca que “em 1830, é promulgado o Código Penal, com dois dispositivos (arts. 178 e 257), que estabeleciam penas para o corte ilegal de madeiras" $" 77$.

Posteriormente, em 1850, foi promulgada a Lei $n^{0}$ 601, estabelecendo punições para a derrubada de matas e queimadas, responsabilizando o infrator, civilmente, com o pagamento de multa e, penalmente, com a prisão que poderia variar de dois a seis meses $^{78}$.

Todavia, foi apenas no período republicado, iniciado em 1889, que apareceram os primeiros diplomas legais setoriais, que iniciam a proteção específica do meio ambiente $^{79}$.

Para Georgette Nacarato Nazo e Toshio Mukai, foi no período compreendido entre as décadas de 1960 e 1970 que "surgem os principais diplomas legais, já com uma preocupação mais concreta com a proteção ambiental”"

A partir da década de 1970, apontam os autores, que as preocupações ambientalistas fortaleceram-se não só no Brasil, mas também em todo o mundo.

\footnotetext{
${ }^{74}$ Idem, ibidem.

${ }^{75}$ Idem, ibidem.

${ }^{76}$ WAINER, Ann Helen. Legislação ambiental do Brasil - Subsídios para a história do direito ambiental. Rio de Janeiro: Forense, 1991. p. 5.

${ }^{77}$ Idem, p. 57.

${ }^{78}$ Idem, ibidem.

${ }^{79}$ NAZO, Georgette Nacarato; MUKAI, Toshio. Op. cit., p. 1066.

${ }^{80}$ Idem, p. 1.067.
} 
Esta década é a mais importante para o início da consolidação das preocupações ambientalistas, pois é em 1972, em Estocolmo, que, sob o patrocínio da ONU [Organização das Nações Unidas], realiza-se a célebre Conferência sobre o Meio Ambiente (de 5 a 16.06.1972) ${ }^{81}$.

Na década de 1980, como aponta Vladimir Passos de Freitas, a evolução do Direito Ambiental continua em aceleração, quando, então, são editados novos importantes diplomas:

na década de oitenta, a evolução [do direito ambiental] se acelerou. Primeiro, por força da Lei da Política Nacional do Meio Ambiente (6.938, de 31.08.1981); depois em razão da Lei da Ação Civil Pública (7.347, de 24.07.1985); finalmente, com a entrada em vigor da nova Constituição Federal $(05.10 .1988)^{82}$.

Em 1992, outro importante evento de cunho ambiental em nível internacional influenciou o Direito Ambiental brasileiro, também organizado pela ONU. Dessa vez, entretanto, o evento foi realizado em solo brasileiro. Tratou-se da Conferência das Nações Unidas sobre Meio Ambiente e Desenvolvimento.

Quanto ao ponto, Georgette Nacarato Nazo e Toshio Mukai anotam:

No campo dos eventos, vários foram realizados, de inegável valia para o desenvolvimento do direito ambiental brasileiro, mas nenhum teve tanta importância para tal como a Conferência das Nações Unidas sobre Meio Ambiente e Desenvolvimento, realizada no Rio de Janeiro, a ECO-92, onde alguns diplomas legais internacionais importantes foram criados e que teve como consequência a aceleração e a difusão da preocupação pelos problemas ambientais, no País e fora dele ${ }^{83}$.

Guido Soares ressalta a evolução ocorrida nos 20 anos que separaram as Conferências de Estocolmo e do Rio de Janeiro, como se observa no trecho a seguir transcrito:

Num evidente clima de urgência de uma regulamentação enérgica sobre o meio ambiente mundial, fortemente motivado pelos graves acidentes que causavam verdadeira comoção pública na maioria dos Estados, além da pressão da opinião pública sobre as diplomaciais dos Estados, aliada aos resultados

\footnotetext{
${ }^{81}$ Idem, p. 1.068.

${ }^{82}$ FREITAS, Vladimir Passos de. A Constituição Federal... cit., p. 15.

${ }^{83}$ NAZO, Georgette Nacarato; MUKAI, Toshio. Op. cit., p. 1.077.
} 
alarmantes de cientistas sobre a situação de desequilíbrio no meio ambiente, a maioria dos países, na $\mathrm{AG}$ da $\mathrm{ONU}$, resolveu convocar uma grande conferência internacional para discutir a questão da preservação do meio ambiente, mas sem perder a dimensão que os países em desenvolvimento insistiam em discutir, conjuntamente: a questão do desenvolvimento e das disparidades de níveis econômicos existentes entre os Estados. A temática da implantação de uma 'nova ordem econômica internacional' não poderia fazer falta nas discussões daquele período, tendo em vista que ela era o tema mais importante de qualquer reunião sob a égide da ONU. As próprias denominações das conferências internacionais de 1972 e 1992 revelam enfoques distintos e, sobretudo, temáticas diferentes; em Estocolmo, em 1972, tinha sido [a] Conferência das Nações Unidas sobre o Meio Ambiente Humano e, em 1992, no Rio de Janeiro, a denominação oficial da ECO-92 foi Conferência das Nações Unidas sobre Meio Ambiente e Desenvolvimento ${ }^{84}$.

Nesse sentido, merece destaque um outro ponto, frequentemente suscitado quando se discute a evolução das discussões ambientais em nível internacional, qual seja, o deslocamento, nas grandes discussões políticas e diplomáticas, do eixo Leste-Oeste (países capitalistas versus países socialistas), para o eixo Norte-Sul (países industrializados versus países em desenvolvimento). A queda do muro de Berlim pôs fim à confrontação entre Leste e Oeste e acompanhou o esfacelamento da antiga União das Repúblicas Socialistas Soviéticas (URSS), deslocando a atenção dos Estados na citada disparidade Norte-Sul e nas questões da pobreza mundial.

Paralelamente, alterou-se a estratégia utilizada para garantir o cumprimento do tratado internacional. O sistema baseado na punição - a exemplo do que ocorreu nos tratados assinados no âmbito da Organização Mundial de Comércio (OMC) - foi substituído por um sistema de benefícios e incentivos, conforme ver-se-á nos tópicos a seguir. Tratou-se de uma tentativa de remediar o problema da eficácia no âmbito internacional, promovendo-se o cumprimento das obrigações internacionais pela via do reforço positivo em detrimento da punição.

Esse sistema também foi adotado em nível nacional pelo Brasil, por motivos diferentes, de forma que já são numerosas as situações em que o ordenamento jurídico previu incentivos para condutas saudáveis ao ambiente, tema que será evidenciado e discutido no presente trabalho.

\footnotetext{
${ }^{84}$ A proteção internacional do meio ambiente. São Paulo: Manole, 2003, p. 44.
} 


\subsection{Princípios resultantes da evolução do Direito Ambiental e a responsabilidade sem dano}

A evolução do Direito Ambiental, seja no âmbito nacional, seja no âmbito internacional, permitiu a criação de diferentes princípios.

Enio Moraes da Silva aponta que, no Brasil,

diversas são as normas e princípios que poderiam ser trazidos à baila como exemplos de instrumentos de proteção ambiental, que procuram garantir a defesa do meio ambiente ${ }^{85}$.

Porém, não nos ocuparemos em citar, indiscriminadamente, cada um destes princípios. Para os fins do presente trabalho, os princípios da precaução e da prevenção merecem destaque, já que estão relacionados à necessidade de se evitar danos ambientais e, portanto, relacionados à proteção do meio ambiente.

Da mesma forma, intimamente relacionada a tais princípios, a responsabilidade sem dano também merecerá comentários, uma vez que, como o próprio nome sugere, aplica-se previamente à ocorrência de danos ambientais.

O princípio da precaução encontra adeptos e críticos fervorosos, motivo pelo qual sua definição e abrangência são temas espinhosos.

Nas palavras de Teresa Ancona Lopez,

o princípio da precaução tem característica de 'princípio jurídico' que tenta realizar os valores do naeminem laedere, da prudência e da segurança (outro princípio) e estabelece diretrizes normativas no sentido de evitar os danos, apreciando os riscos possíveis para que o pior não aconteça individual ou socialmente $^{86}$.

\footnotetext{
${ }^{85}$ SILVA, Enio Moraes da. Os organismos geneticamente modificados e o princípio da precaução como instrumento de proteção ambiental. In: MILARÉ, Édis; MACHADO, Paulo Affonso Leme (Orgs.). Direito Ambiental: direito ambiental internacional e temas atuais. São Paulo: RT, 2011, p. 746.

${ }^{86}$ LOPEZ, Teresa Ancona. Op. cit., p. 95.
} 
A precaução e a sua "irmã", a prevenção, sempre existiram no mundo, sendo preteritamente aplicadas de forma intuitiva e empírica, fruto do medo e da insegurança que sempre estiveram presentes no meio social. Porém, os tipos de perigo eram consideravelmente diferentes e mais amenos daqueles que se apresentam atualmente.

Os registros apontam que a primeira manifestação escrita do princípio da precaução foi a Charte que Jean de Lévis de Mirapoix editou, em 1303, para regulamentar a venda de carne naquela cidade a fim de enfrentar os perigos não identificados naquela época ${ }^{87}$.

No mundo contemporâneo, o princípio da precaução foi introduzido pelo Direito Ambiental, já tendo sido discutido na Conferência das Nações Unidas Sobre Meio Ambiente Humano, de 1972. Porém, foi apenas em 1992, na Conferência das Nações Unidas Sobre Meio Ambiente e Desenvolvimento, reconhecido como princípio, na "Declaração do Rio de Janeiro", conforme verbis:

Princípio 15: Com o fim de proteger o meio ambiente, o princípio da precaução deverá ser amplamente observado pelos Estados, de acordo com suas capacidades. Quando houver ameaça de danos graves ou irreversíveis, a ausência de certeza científica absoluta não será utilizada como razão para o adiamento de medidas economicamente viáveis para prevenir a degradação ambiental $^{88}$.

Referido texto, vale dizer, foi inspirado na decisão do litígio ocorrido entre o Canadá e os Estados Unidos, na década de 40 do século passado, a respeito de uma questão de poluição atmosférica de natureza transfronteiriça.

Trata-se do caso da Fundição Trail, uma empresa de fundição de cobre, situada na cidade de Trail (Canadá), que emitia fumaça e pequenas partículas que atravessavam a fronteira entre os dois países e prejudicavam as cidades e as propriedades dos cidadãos norte-americanos. Tendo repercutido no cenário internacional, o caso Fundição Trail acabou por incorporar no Direito Internacional Ambiental a ideia de poluição transfronteiriça, bem como da necessidade de precaução para evitar danos irreversíveis.

\footnotetext{
${ }^{87}$ Idem, p. 97.

${ }^{88}$ Disponível em: <http://www.onu.org.br/rio20/img/2012/01/rio92.pdf>. Acesso em: 31 março 2014.
} 
Os tribunais brasileiros, notadamente em questões ambientais, têm aplicado em larga escala o princípio da precaução, seja como premissa para conclusões, seja como fundamento para decidir. É o que se percebe dos julgados citados abaixo.

MANDADO DE SEGURANÇA. LICENÇA DE OPERAÇÃO. Alegação de ausência dos requisitos autorizadores da liminar. Agravante aponta irregularidades no auto posto que impedem a concessão da licença de operação. Possibilidade. Risco de lesão grave ou de difícil reparação em desfavor do meio ambiente. Atividade desenvolvida causa impacto ambiental. Aplicação dos princípios da precaução e prevenção. Dado provimento ao agravo para cassar a liminar concedida em primeira instância (A.I. no 023649312.2011.8.26.0000, Rel. Ruy Alberto Leme Cavalheiro, Câmara Reservada ao Meio Ambiente do Tribunal de Justiça de São Paulo, j. 17.05.2012) ${ }^{89}$.

AGRAVO DE INSTRUMENTO. AÇÃO CIVIL PÚBLICA AMBIENTAL. Determinação judicial para cessar toda e qualquer atividade relacionada à edificação de shopping center e torre comercial. Verificada a ausência do interesse de agir, na medida em que a determinação não engloba a continuidade de processo administrativo junto aos órgãos ambientais municipais. Questão, no mérito, que deve ser vista a partir dos princípios norteadores do meio ambiente saudável, em especial a precaução e a prevenção. Agravo desprovido. (A.I. $\mathrm{n}^{\circ}$ 0068326-32.2011.8.26.0000, Rel. Renato Nalini, Câmara Reservada ao Meio Ambiente do Tribunal de Justiça de São Paulo, j. 29.03.2012) ${ }^{90}$.

AGRAVO DE INSTRUMENTO - AÇÃO CIVIL PÚBLICA - Construção na Serra dos Cristais em Diamantina - Bem tombado pelo IEPHA - Discussão dos efeitos da construção para o patrimônio natural - Liminar para paralisação das obras - Manutenção - Princípio da Precaução (A.I. no 1.0216.09.0657869/001, Rel. Elias Camilo, TJMG, j. 14.01.2009) ${ }^{91}$.

AGRAVO DE INSTRUMENTO. AÇÃO DE OBRIGAÇÃO DE FAZER. DIREITO AMBIENTAL. Pretensão de autorização de corte de árvores para realizar empreendimento imobiliário. Tutela antecipada indeferida. Área de floresta em estágio médio de regeneração, localizada na "APA do Passaúna". Prevalência do princípio da precaução na espécie. Medida antecipatória que se afigura irreversível. Requisitos da tutela antecipada ausentes (art. 273, CPC). Pretensão de indenização por suposta desapropriação indireta que exige dilação probatória. Recurso não provido (A.I. n ${ }^{\circ}$ 834.475-8, Rel. Rogério Ribas, TJPR, j. 24.01 .2012$)^{92}$.

\footnotetext{
${ }^{89}$ Disponível em:

$<$ http://esaj.tjsp.jus.br/cjsg/getArquivo.do? cdAcordao $=5909213 \&$ cdForo $=0 \& v 1 C a p t c h a=R M w s V>$. Acesso em: 31 março 2014.

${ }^{90}$ Disponível em: $<$ http://esaj.tjsp.jus.br/cjsg/getArquivo.do?cdAcordao=5795312\&cdForo=0 $>$. Acesso em: 31 março 2014.

91 Disponível em: <http://www5.tjmg.jus.br/jurisprudencia/formEspelhoAcordao.do>. Acesso em: 31 março 2014.

92 Disponível em: <http://portal.tjpr.jus.br/jurisprudencia/j/11223276/Ac\%C3\%B3rd\%C3\%A3o-8344758>. Acesso em: 31 março 2014.
} 
Em continuidade, sobre o princípio da prevenção, Édis Milaré ensina que se refere a riscos ou impactos já conhecidos pela ciência, ao passo que a precaução se destina a gerir riscos ou impactos desconhecidos ${ }^{93}$.

Em outros termos,

enquanto a prevenção trabalha com o risco certo, a precaução vai além e se preocupa com o risco incerto. Ou ainda, a prevenção se dá em relação ao perigo concreto, ao passo que a precaução envolve perigo abstrato ${ }^{94}$.

Aplica-se o princípio da prevenção, portanto, quando o perigo é certo e quanto se tem elementos seguros para afirmar que uma determinada atividade é efetivamente perigosa.

Quanto ao tema, Patrícia Faga Iglecias Lemos ensina:

$\mathrm{O}$ art. 225 da CF prevê implicitamente o referido princípio ao mencionar o dever de preservação do meio ambiente que se impõe à coletividade e ao Poder Público. Além disso, trata de diversos mecanismos preventivos do dano, como a exigência de estudo prévio de impacto ambiental nos casos de atividade potencialmente causadora de dano ao meio ambiente; o dever do Estado de controlar a produção, a comercialização e o emprego de técnicas, métodos e substâncias que impliquem risco para a vida, a qualidade de vida e ao meio ambiente; a preservação da diversidade e da integridade do patrimônio genético, além da previsão de participação popular, que, por exemplo, em audiências públicas, pode auxiliar na prevenção de danos.

Com isso, impende reconhecer que toda a ação do direito ambiental está voltada para uma tutela preventiva, pois a coação a posteriori revela-se ineficaz. Isso quer dizer que os recursos ambientais devem ser utilizados de forma racional ${ }^{95}$.

Tal como a Medicina, ao menos como ela foi entendida até o momento, o Direito não tem a função de prevenir as doenças sociais, mas, sim, de tratá-las quando já se irromperam, ainda que nem sempre seja capaz de curá-las. Dentre as funções que são mais frequentemente atribuídas ao Direito estão a repressão dos comportamentos desviantes e a resolução de conflitos de interesses particulares. Ambas são funções terapêuticas.

\footnotetext{
${ }^{93}$ MILARÉ, Édis. Direito do ambiente. 6. ed. São Paulo: RT, 2009, p. 823.

${ }^{94}$ Idem, ibidem.

${ }^{95}$ LEMOS, Patrícia Faga Iglecias. Direito ambiental... cit., p. 174.
} 
A comparação com a Medicina é válida porque, hoje, boa parte dos médicos e cientistas está voltada para impedir que as doenças se instalem e não para tratá-las quando já se instalaram. De maneira semelhante, o Direito passa a assumir a mesma tendência, deixando cada vez mais de lado a sua função repressiva e focando nos estímulos e na prevenção.

A evolução tecnológica e o aumento exponencial dos riscos exigem dos operadores do Direito a flexibilização das regras da responsabilidade civil, de forma a prevenir danos, os quais, muitas vezes, são irreversíveis. Nasce o que a doutrina denomina responsabilidade preventiva.

Nesse sentido, ensina Teresa Ancona Lopez:

(...) não vemos inconveniente em ampliar ou estender a noção de responsabilidade para a prevenção ou precaução dos danos possíveis, graves ou irreversíveis, pois a ideia fundamentadora de todo o sistema de responsabilidade civil é a da proibição de causar dano a outrem (alterum non laedere). Ora, uma função da responsabilidade civil que impeça a realização de danos estará garantindo a integridade física, moral e econômica dos cidadãos individualmente e da sociedade inteira ${ }^{96}$.

Teresa Ancona Lopez justifica a aplicabilidade da responsabilidade sem dano e explica que o instrumento é resultado da adoção dos princípios da precaução e da prevenção com a finalidade de dar mais segurança a todos os cidadãos. Foi necessária a flexibilização da interpretação e da aplicação dos institutos da responsabilidade civil ${ }^{97}$.

Como alguns autores já têm proposto, a responsabilidade civil tem funções ressarcitória, dissuasória e preventiva.

A função preventiva deverá englobar as atitudes de prevenção e de precaução. Dentro da evolução da responsabilidade civil, que acompanha a mudança social e econômica, a função preventiva tem caráter antecipatório e foi expandida em razão dos riscos crescentes. Portanto, responsabilidade civil não se resume ao ressarcimento de

\footnotetext{
${ }^{96}$ LOPEZ, Teresa Ancona. Op. cit., p. 137.

${ }^{97}$ Idem, p. 135. A autora explica que, no Brasil, tal flexibilização só existe no âmbito do Direito Ambiental, por enquanto.
} 
danos (apesar de ainda ser essa sua principal função); é, também, prevenção e precaução de eventos danosos.

Daí porque, aos olhos de Teresa Ancona Lopez e outros respeitáveis doutrinadores brasileiros e estrangeiros, é possível a responsabilidade civil sem dano. 


\title{
CAPÍTULO 3 - O REGIME DE SANÇÕES NEGATIVAS
}

Como citado no Capítulo anterior, a norma pode ser negativa ou positiva, acompanhada ou não de sanções positivas (incentivos) ou negativas (punições). Neste Capítulo, serão tratadas as sanções negativas e sua aplicabilidade no Direito brasileiro, em especial no Direito Ambiental.

Hans Kelsen define sanções como "atos de coerção que são estatuídos contra uma ação ou omissão determinada pela ordem jurídica",98 . E continua:

\begin{abstract}
as sanções no sentido específico desta palavra aparecem - no domínio das ordens jurídicas estaduais - sob duas formas diferentes: como pena (no sentido estrito da palavra) e como execução (execução forçada). Ambas as espécies de sanções consistem na realização compulsória de um mal ou - para exprimir o mesmo sob a forma negativa - na privação compulsória de um bem ${ }^{99}$.
\end{abstract}

Tais ensinamentos permitem inferir que a sanção negativa deverá ser aplicada sempre que houver uma conduta indesejada, punível nos termos da lei. Insere-se no que denominaram-se técnicas de desencorajamento no Capítulo anterior.

Existem três modos típicos de impedir uma ação não desejada: torná-la impossível, torná-la difícil ou torná-la desvantajosa. Tais modos poderão agir nos comportamentos já realizados ou naqueles que ainda virão ou estão se desenvolvendo.

As sanções negativas podem se distinguir em medidas retributivas, ou penas propriamente ditas, e em medidas reparadoras, como o ressarcimento do dano. No primeiro caso, atingem a própria ação não conforme; no segundo caso, buscam aplicar um remédio às consequências da ação não conforme.

\footnotetext{
${ }^{98}$ KELSEN, Hans. Op. cit., p. 121.

${ }^{99}$ Idem, ibidem.
} 
Quanto ao tema, Patrícia Faga Iglecias Lemos ensina que a diferenciação entre a pena e a reparação deu-se a partir dos romanos, com a distinção entre delitos públicos e privados $^{100}$. Até então, tanto o Estado quanto os particulares tinham o direito de punir.

Quando a ação repressiva passou para o Estado, surgiu a ação de indenização. A responsabilidade civil tomou lugar ao lado da responsabilidade penal.

Em sua função repressiva, o Estado faz uso de instrumentos de comando e controle $^{101}$, a fim de garantir o cumprimento dos objetivos de determinada política. Baseiam-se em determinações de cunho administrativo e no poder de polícia; seu descumprimento acarreta a imposição de sanções.

$\mathrm{Na}$ política ambiental brasileira, os instrumentos de comando e controle são predominantes. Existe um conjunto extenso de normas e exigências para o cumprimento de padrões, determinando condutas específicas, criando restrições ou proibindo práticas, a fim de propiciar a proteção do meio ambiente.

A Lei $\mathrm{n}^{\mathrm{o}} 6.938 / 1981^{102}$ cria a Política Nacional do Meio Ambiente, estabelecendo uma modalidade de gestão integrada dos recursos naturais, com princípios, objetivos, instrumentos e uma estrutura institucional, o Sistema Nacional do Meio Ambiente (SISNAMA).

A lei prevê 13 tipos de instrumentos ${ }^{103}$, em sua maior parte de natureza de comando e controle, dos quais merecem destaque: (i) padrões de qualidade ambiental; (ii)

\footnotetext{
${ }^{100}$ LEMOS, Patrícia Faga Iglecias. Direito ambiental... cit., p. 118.

${ }^{101} \mathrm{Cf}$. comentários sobre instrumentos de comando e controle no Capítulo 1.

102 BRASIL. Lei ${ }^{\circ} 6.938$ de 31 de agosto de 1981. Disponível em: <http://www.planalto.gov.br/ccivil_03/leis/16938.htm>. Acesso em: 31 março 2014.

${ }^{103}$ Cf. artigo $9^{\circ}$ da Lei no 6.938/1981. "Art. $9^{\circ}$ São instrumentos da Política Nacional do Meio Ambiente: I - o estabelecimento de padrões de qualidade ambiental; II - o zoneamento ambiental; III - a avaliação de impactos ambientais; IV - o licenciamento e a revisão de atividades efetiva ou potencialmente poluidoras; $\mathrm{V}$ - os incentivos à produção e instalação de equipamentos e a criação ou absorção de tecnologia, voltados para a melhoria da qualidade ambiental; VI - a criação de espaços territoriais especialmente protegidos pelo Poder Público federal, estadual e municipal, tais como áreas de proteção ambiental, de relevante interesse ecológico e reservas extrativistas; VII - o sistema nacional de informações sobre o meio ambiente; VIII - o Cadastro Téenico Federal de Atividades e Instrumentos de Defesa Ambiental; IX - as penalidades disciplinares ou compensatórias ao não cumprimento das medidas necessárias à preservação ou correção da degradação ambiental; X - a instituição do Relatório de Qualidade do Meio Ambiente, a ser divulgado anualmente pelo Instituto Brasileiro do Meio Ambiente e Recursos Naturais Renováveis - IBAMA; XI - a garantia da prestação de informações relativas ao Meio Ambiente, obrigando-se o Poder Público a produzi-
} 
zoneamento ambiental; (iii) avaliação de impactos ambientais; (iv) licenciamento ambiental; (v) penalidades disciplinares ou compensatórias; (vi) criação de espaços territoriais especialmente protegidos e (vii) relatório de qualidade do meio ambiente.

Todavia, com a promulgação da Lei $\mathrm{n}^{\mathrm{o}} 11.284 / 2006^{104}$, a Política Nacional de Meio Ambiente passou a englobar o uso de instrumentos econômicos ${ }^{105}$ como alternativa à proteção do meio ambiente. São citados como modalidades de tais instrumentos a concessão florestal, a servidão ambiental e o seguro ambiental ${ }^{106}$.

Quanto ao ponto, Peter H. May, Carlos Amaral, Brent Millikan e Petra Ascher apontam um rol maior de instrumentos econômicos, a saber ${ }^{107}$ : (i) subsídios creditícios para atividades realizadas de forma ambientalmente amena; (ii) isenção fiscal ou tarifária para atividades que cumprem as normas ambientais; (iii) taxas sobre resíduos emitidos para desincentivar o despejo ao ambiente; (iv) taxas vinculadas ao uso de recursos naturais visando evitar a exaustão; (v) impostos ambientais vinculados à taxação convencional; (vi) certificados de emissão ou direitos de uso comercializáveis; (vii) rotulação ambiental com base em certificação de origem sustentável e (viii) instrumentos de responsabilização legal ou securitização por danos.

O funcionamento do sistema de comando e controle é caro e tem defeitos, principalmente em um País de dimensões continentais como o Brasil. O legislador buscou, mediante a criação do SISNAMA, estruturar órgãos federais, estaduais e municipais que pudessem garantir a capilaridade da atuação do Estado, mas a extensão territorial do País parece ser uma barreira intransponível.

las, quando inexistentes; XII - o Cadastro Técnico Federal de atividades potencialmente poluidoras e/ou utilizadoras dos recursos ambientais; XIII - instrumentos econômicos, como concessão florestal, servidão ambiental, seguro ambiental e outros" (BRASIL. Lei n ${ }^{\circ} 6.938$ de 31 de agosto de 1981. Disponível em: $<$ http://www.planalto.gov.br/ccivil_03/leis/16938.htm>. Acesso em: 31 março 2014).

${ }^{104}$ BRASIL. Lei $\mathrm{n}^{\circ} 11.284$, de 2 de março de 2014. Disponível em:

$<$ http://www.planalto.gov.br/ccivil_03/_ato2004-2006/2006/lei/111284.htm>. Acesso em: 31 março 2014.

${ }^{105}$ Cf. comentários sobre instrumentos econômicos no Capítulo 1.

${ }^{106}$ Cf. artigo 84 da Lei ${ }^{\circ} 11.284 / 2006$. “Art. 84. A Lei $n^{\circ}$ 6.938, de 31 de agosto de 1981, passa a vigorar com as seguintes alterações: Art. $9^{\circ}$

XIII - instrumentos econômicos, como concessão florestal, servidão ambiental, seguro ambiental e outros" (BRASIL. Lei $\mathrm{n}^{\mathrm{o}} 11.284$, de 2 de março de 2014. Disponível em: $<$ http://www.planalto.gov.br/ccivil_03/_ato2004-2006/2006/lei/111284.htm>. Acesso em: 31 março 2014).

107 Instrumentos econômicos para o desenvolvimento sustentável da Amazônia brasileira. Brasília: Ministério do Meio Ambiente, 2005. Disponível em:

$<$ http://www.mma.gov.br/estruturas/168/_publicacao/168_publicacao30012009115059.pdf>. Acesso em: 31 março 2014. 
Note-se que a baixa probabilidade de detectação de irregularidades aumenta a probabilidade de descumprimento das normas. Há, ainda, a dificuldade de se estabelecer os padrões corretos, em vista das constantes inovações da indústria e demais atividades econômicas.

Werner Grau Neto pondera que, nos regimes em que se adota o comando e controle como mote central, a exemplo do que faz a Política Nacional do Meio Ambiente no Brasil,

é de regra que, cumpridas as exigências desse sistema e obtido o licenciamento ambiental, não esteja o empreendedor sujeito a qualquer espécie de sanção, seja a que título for, desde que atendidos os regramentos postos para a obtenção do licenciamento ${ }^{108}$.

Por outro lado, segundo Werner Grau Neto:

nos Estados Democráticos de Direito, em que o Estado intervém o mínimo possível sobre as atividades econômicas, o sistema do comando e controle perde espaço para a adoção do regime de responsabilidade pelo resultado da atividade. Vale dizer, o empreendedor goza de liberdade maior para empreender, mas responde de forma ampla pelos resultados de sua atividade que se revelem lesivos aos bens sob proteção do Estado, tais como o meio ambiente ${ }^{109}$.

Ainda aponta que essa atuação rígida e intervencionista do Estado demanda atuação constante dos órgãos estatais, onerando excessivamente o erário, e sujeitando o sistema como um todo à ineficiência, sempre que ausentes recursos financeiros ou materiais para a aplicação das suas ferramentas ${ }^{110}$.

\footnotetext{
${ }^{108}$ GRAU NETO, Werner. Op. cit., p. 16.

${ }^{109}$ Idem, ibidem.

${ }^{110}$ Idem, p. 17.
} 
Apenas a título de ilustração, no ano de 2012, os cofres públicos arcaram com aproximadamente 30 bilhões de reais para o Poder Judiciário ${ }^{111}$ e 1,1 bilhão de reais para o Instituto Brasileiro do Meio Ambiente e dos Recursos Naturais Renováveis $(\text { IBAMA })^{112}$.

Previu-se, no orçamento da União, gastos na ordem de 2,3 bilhões de reais com o Ministério Público Federal ${ }^{113}$.

No Estado de São Paulo, também para o ano de 2012, a Companhia Ambiental do Estado de São Paulo (CETESB) previu em seu orçamento gastos no valor de R\$ 348.846.951,00 $0^{114}$. Para o mesmo ano, o Ministério Público do Estado de São Paulo previu gastos de $\mathrm{R} \$ 1.532 .278 .218,00^{115}$.

Considerando tais dados, é possível notar quão significativos são os gastos dos principais órgãos investigadores, fiscalizadores e sancionadores do sistema jurídico brasileiro.

\footnotetext{
${ }^{111}$ Informações constantes da "Execução Orçamentária dos Órgãos do Poder Judiciário Integrantes do Orçamento Geral da União (OGU) - Exercício 2012". Disponível em: <www.cnj.jus.br>. Acesso em: 31 março 2014.

112 Informações constantes da "Execução Orçamentária" do IBAMA. Disponível em: <www.ibama.gov.br>. Acesso em: 31 março 2014.

113 Informações constantes do documento "Orçamentos da União - Exercício Financeiro 2012" do Ministério do Planejamento, Orçamento e Gestão do Governo Federal. Disponível em: $<$ http://www.planejamento.gov.br/secretarias/upload/Arquivos/sof/ploa2012/110831_ploa2012_vol3.pdf $>$. Acesso em: 31 março 2014.

114 Informações constantes do "Orçamento do Estado 2012", da Secretaria de Planejamento e Desenvolvimento Regional do Governo do Estado de São Paulo. Disponível em: $<$ http://www.planejamento.sp.gov.br/noti_anexo/files/planejamento_orcamento/orcamentos/2011/Lei_1467 5 de_28_12_11.pdf $>$. Acesso em: 31 março 2014.

$11 \overline{5}$ Informações constantes do "Orçamento do Estado 2012", da Secretaria de Planejamento e Desenvolvimento Regional do Governo do Estado de São Paulo. Disponível em: $<$ http://www.planejamento.sp.gov.br/noti_anexo/files/planejamento_orcamento/orcamentos/2011/Lei_1467 5_de_28_12_11.pdf $>$. Acesso em: 31 março 2014.
} 


\subsection{As sanções negativas no Direito Ambiental}

Após a ocorrência de um dano ambiental, o sistema jurídico volta-se à definição das responsabilidades - que, no âmbito do Direito Ambiental, dividem-se nas esferas civil, criminal e administrativa ${ }^{116}$.

Em âmbito civil, a responsabilidade é tratada pela Lei $n^{0} 6.938 / 1981^{117}$, a qual prevê a obrigação de indenizar ou reparar os danos causados ao meio ambiente, independentemente da existência de culpa (artigo 14, $\S 1^{0^{118}}$ ). A indenização, tradicionalmente, visa a constituir uma espécie de compensação pelos sofrimentos resultantes do ato infracional e costuma vir acompanhada de uma obrigação de fazer (tal como o retorno ao status quo ante) ou de não fazer.

Em razão da dispensa de culpa, trata-se de responsabilidade objetiva. Como consequência da adoção desse regime, pode-se dizer que a responsabilidade civil ambiental depende, apenas e tão somente, da presença dos seguintes elementos: (i) a ação ou omissão; (ii) o dano ambiental e (iii) o nexo de causalidade entre a lesão e uma determinada atividade.

\footnotetext{
${ }^{116}$ A Constituição Brasileira define, em seu artigo 225, § $3^{\circ}$, que "Art. 225. Todos têm direito ao meio ambiente ecologicamente equilibrado, bem de uso comum do povo e essencial à sadia qualidade de vida, impondo-se ao Poder Público e à coletividade o dever de defendê-lo e preservá- lo para as presentes e futuras gerações. (...) $\$ 3^{\circ}$ As condutas e atividades consideradas lesivas ao meio ambiente sujeitarão os infratores, pessoas físicas ou jurídicas, a sanções penais e administrativas, independentemente da obrigação de reparar os danos causados" (BRASIL. Constituição Federal (1988). Disponível em: $<$ http://www.planalto.gov.br/ccivil_03/constituicao/constituicao.htm>. Acesso em: 31 março 2014).

117 BRASIL. Lei $\mathrm{n}^{\mathrm{0}} 6.938$ de 31 de agosto de 1981. Disponível em: <http://www.planalto.gov.br/ccivil_03/leis/16938.htm>. Acesso em: 31 março 2014.

${ }^{118}$ Cf. artigo 14 da Lei ${ }^{\circ}$ 6.938/1981. "Art 14. Sem prejuízo das penalidades definidas pela legislação federal, estadual e municipal, o não cumprimento das medidas necessárias à preservação ou correção dos inconvenientes e danos causados pela degradação da qualidade ambiental sujeitará os transgressores: $\S 1^{\circ}$ Sem obstar a aplicação das penalidades previstas neste artigo, é o poluidor obrigado, independentemente da existência de culpa, a indenizar ou reparar os danos causados ao meio ambiente e a terceiros, afetados por sua atividade. O Ministério Público da União e dos Estados terá legitimidade para propor ação de responsabilidade civil e criminal, por danos causados ao meio ambiente" (BRASIL. Lei $\mathrm{n}^{\circ} 6.938$ de 31 de agosto de 1981. Disponível em: <http://www.planalto.gov.br/ccivil_03/leis/16938.htm>. Acesso em: 31 março 2014).
} 
Nesse sentido, Patrícia Faga Iglecias Lemos registra:

A responsabilidade objetiva, prevista em lei ou decorrente da atividade de risco, afasta-se da ideia inicial em que pressupostos são a ação ou a omissão, o dano, o nexo de causalidade e a culpa, para estabelecer como pressupostos a ação ou a omissão, a relação de causalidade e o dano. Assim, não há que se falar em comprovação da culpa ${ }^{119}$.

Neste caso, a pena que poderá ser imposta ao infrator será o pagamento de indenização para a devida reparação dos danos causados, os quais podem ser patrimoniais, morais ou ambos.

Nas palavras de Patrícia Faga Iglecias Lemos,

não basta a reparação dos danos materiais efetivamente causados. Há necessidade de que, configurado o dano moral, seja o seu valor acrescido a título de justa indenização ${ }^{120}$.

Daí se nota que a indenização a ser paga pelo infrator pelos danos ambientais causados pode atingir valores consideráveis. Mais uma vez utilizando os ensinamentos de Patrícia Faga Iglecias Lemos, caberá ao magistrado, em ação judicial própria, definir os valores da condenação, levando-se em consideração o objetivo de alcançar efetiva e integral reparação ou compensação do dano causado ${ }^{121}$.

Por sua vez, a responsabilidade penal é subjetiva, isto é, depende de prova de dolo ou culpa por parte do agente, além dos demais requisitos legais, como a tipicidade e a antijuridicidade.

Nos termos da Lei $n^{0}$ 9.605/1998 ${ }^{122}$, a Lei de Crimes Ambientais, responde por crime ambiental quem, comprovadamente, lhe deu causa, seja pessoa física ou jurídica. Noutras palavras, tem-se que a sanção penal é personalíssima, devendo ser cumprida pelo próprio agente que praticou a conduta.

\footnotetext{
${ }^{119}$ LEMOS, Patrícia Faga Iglecias. Direito ambiental... cit., p. 123-124.

${ }^{120}$ Idem, p. 166.

${ }^{121}$ Idem, ibidem.

122 BRASIL. Lei $\mathrm{n}^{\mathrm{o}}$ 9.605, de 12 de fevereiro de 1998. Disponível em: $<$ http://www.planalto.gov.br/ccivil_03/leis/19605.htm>. Acesso em: 31 março 2014.
} 
Em termos práticos, desde 1998, as pessoas jurídicas podem ser responsabilizadas criminalmente, desde que se verifique: (i) que a infração tenha sido cometida em interesse ou benefício da empresa e (ii) por decisão de seu representante legal ou contratual, ou de seu órgão colegiado, nos ditames do artigo $3^{\circ}$ da Lei de Crimes Ambientais $^{123}$.

Note-se, também, que a responsabilidade das pessoas jurídicas não exclui a das pessoas físicas, autoras, coautoras ou partícipes do mesmo fato, na medida em que a empresa, por si própria, não comete crimes.

As penas aplicáveis são (i) privativas de liberdade, (ii) restritivas de direito ou (iii) multas. Tais sanções são aplicáveis a pessoas físicas ou jurídicas, ressalvada a hipótese de pena privativa de liberdade, a qual só pode ser aplicada a pessoa física, por motivos que dispensam nossos comentários.

Édis Milaré descreve a aplicação de tais penas: a pena privativa de liberdade envolve as tradicionais reclusão e retenção, para o caso de ocorrência de crime, e a prisão simples, para o caso de contravenção ${ }^{124}$.

Em continuidade, segundo Édis Milaré, as penas restritivas de direitos compreendem, para pessoas físicas ${ }^{125}$ :

- Prestação de serviços à comunidade, que consiste na atribuição ao condenado de tarefas gratuitas junto a parques e jardins públicos e unidades de conservação e, no caso de dano da coisa particular, pública ou tombada, na restauração desta, se possível;

\footnotetext{
${ }^{123}$ Cf. artigo $3^{\circ}$ da Lei ${ }^{\circ} 9.605 / 1998$. “Art. $3^{\text {o }}$ As pessoas jurídicas serão responsabilizadas administrativa, civil e penalmente conforme o disposto nesta Lei, nos casos em que a infração seja cometida por decisão de seu representante legal ou contratual, ou de seu órgão colegiado, no interesse ou benefício da sua entidade" (BRASIL. Lei $\mathrm{n}^{\circ}$ 9.605, de 12 de fevereiro de 1998. Disponível em: $<$ http://www.planalto.gov.br/ccivil_03/leis/19605.htm>. Acesso em: 31 março 2014).

${ }^{124}$ MILARÉ, Édis. Direito do ambiente... cit., p. 993.

${ }^{125}$ Idem, ibidem.
} 
- Interdição temporária de direitos, que importa na proibição do condenado contratar com o Poder Público, de receber incentivos fiscais ou quaisquer outros benefícios, bem como de participar de licitações, pelo prazo de cinco anos, no caso de crimes dolosos, e de três anos, no caso de crimes culposos;

- Suspensão parcial ou total de atividades, aplicável quando estas não estiverem obedecendo às prescrições legais;

- Prestação pecuniária, consistente no pagamento em dinheiro à vítima ou à entidade pública ou privada com fim social, de importância, fixada pelo juiz, não inferior a um salário mínimo nem superior a 360 salários mínimos;

- Recolhimento domiciliar, que se baseia na autodisciplina e senso de responsabilidade do condenado, que deverá, sem vigilância, trabalhar, frequentar curso ou exercer atividade autorizada, permanecendo recolhido nos dias e horários de folga em residência ou em qualquer local destinado à sua moradia habitual, conforme estabelecido na sentença condenatória.

Também aponta que tais penas substituem as penas privativas de liberdade nos casos em que (i) se tratar de crime culposo; (ii) for aplicada pena privativa de liberdade inferior a quatro anos ou (iii) a culpabilidade, os antecedentes, a conduta social e a personalidade do condenado, bem como os motivos e as circunstâncias do crime indicarem que a substituição seja suficiente para efeitos de reprovação e prevenção do crime $^{126}$.

Para as pessoas jurídicas, ensina que as penas restritivas de direitos podem ser:

- Suspensão parcial ou total de atividades, aplicável quando estas não estiverem obedecendo às disposições legais ou regulamentares, relativas à proteção do meio ambiente;

- Interdição temporária do estabelecimento, obra ou atividade, aplicável quando estiverem funcionando sem a devida autorização, ou em desacordo com a concedida, ou com violação de disposição legal ou regulamentar;

${ }^{126}$ Idem, ibidem. 
- Proibição de contratar com o Poder Público, bem como dele obter subsídios, subvenções ou doações, pelo prazo de até dez anos, em caso de descumprimento de normas, critérios e padrões ambientais;

- Prestação de serviços à comunidade, consistente em: custeio de programas e de projetos ambientais; execução de obras de recuperação de áreas degradadas; manutenção de espaços públicos; contribuições a entidades ambientalistas ou culturais públicas.

Ainda, Édis Milaré aponta que a terceira modalidade de pena na responsabilidade penal, qual seja, a multa, será calculada segundo os critérios do Código Penal $^{127}$. Destaca que, se revelada ineficaz, ainda que aplicada no valor máximo, a multa poderá ser aumentada até três vezes, tendo em vista o valor da vantagem econômica auferida $^{128}$.

Com relação às penas aplicáveis na responsabilidade penal, Patrícia Faga Iglecias Lemos leciona:

(...) as penas aplicadas, na grande generalidade, não ultrapassarão quatro anos. Encontramos a pena máxima acima de quatro anos, no art. 35 (pesca mediante o uso de explosivos ou de substâncias tóxicas), no art. 40 (causar danos às unidades de conservação) e no art. $54, \S 2^{\circ}$ (poluição qualificada). A prática forense mostra que não se aplica no Brasil o máximo da pena, sendo, portanto, lógico concluir-se que a pena de prisão, a não ser na reincidência, não será efetivamente cominada ao criminoso ambiental ${ }^{129}$.

Por fim, a responsabilidade administrativa ${ }^{130}$ está ligada às condutas que violem “as regras jurídicas de uso, gozo, promoção, proteção e recuperação do meio ambiente", nos moldes do artigo 70 da Lei $n^{0}$ 9.605/1998. A prática de uma infração administrativa poderá dar ensejo à lavratura, por parte dos órgãos ambientais competentes, de um Auto de Infração Ambiental, com imposição de penalidades.

São previstos 10 tipos de sanções, quais sejam: (i) advertência; (ii) multa simples; (iii) multa diária; (iv) apreensão dos animais, produtos e subprodutos da fauna e

\footnotetext{
${ }^{127}$ MILARÉ, Édis. Direito do ambiente... cit., p. 995.

${ }^{128}$ Idem, ibidem.

${ }^{129}$ LEMOS, Patrícia Faga Iglecias. Direito ambiental..., p. 226.

${ }^{130}$ Há significativa divergência na doutrina quanto ao caráter subjetivo ou objetivo da responsabilidade administrativa.
} 
flora, instrumentos, petrechos, equipamentos ou veículos de qualquer natureza utilizados na infração; (v) destruição ou inutilização do produto; (vi) suspensão de venda e fabricação do produto; (vii) embargo de obra ou atividade; (viii) demolição de obra; (ix) suspensão parcial ou total de atividades e (x) restritiva de direitos ${ }^{131}$.

A multa é uma das penalidades mais utilizadas no âmbito da responsabilidade administrativa. De acordo com a legislação brasileira, o valor mínimo de uma multa é R\$ 50,00 e o máximo é R\$50.000.000,00 ${ }^{132}$.

Muito resumidamente, como restou demonstrado, pode-se concluir que a responsabilidade ambiental encontra lastro nas Leis $n^{\circ} 6.938 / 1981^{133}$ e $n^{\circ} 9.605 / 1998^{134}$, no Decreto $n^{\circ} 6.514 / 2008^{135}$ e na Constituição Federal de $1988^{136}$.

Como se nota, o sistema de responsabilidade ambiental está voltado para punir condutas indesejáveis, sem espaço para a previsão de sanções positivas às condutas que possam ser saudáveis ao meio ambiente, mesmo que a imposição da maior parte das penas não traga benefícios à sociedade e, muito menos, para o meio ambiente, a não ser que sejam, necessariamente, acompanhados da reparação efetiva do dano ambiental.

\footnotetext{
${ }^{131}$ Cf. artigo 72 da Lei n ${ }^{\circ}$ 9.605/1998. “Art. 72. As infrações administrativas são punidas com as seguintes sanções, observado o disposto no art. $6^{\circ}$ : I - advertência; II - multa simples; III - multa diária; IV apreensão dos animais, produtos e subprodutos da fauna e flora, instrumentos, petrechos, equipamentos ou veículos de qualquer natureza utilizados na infração; V - destruição ou inutilização do produto; VI suspensão de venda e fabricação do produto; VII - embargo de obra ou atividade; VIII - demolição de obra; IX - suspensão parcial ou total de atividades; X - (VETADO); XI - restritiva de direitos" (BRASIL. Lei ${ }^{\circ}$ 9.605, de 12 de fevereiro de 1998. Disponível em: <http://www.planalto.gov.br/ccivil_03/leis/19605.htm>. Acesso em: 31 março 2014).

${ }^{132}$ Cf. artigo $9^{\circ}$ do Decreto $\mathrm{n}^{\circ}$ 6.514/2008. "Art. $9^{\circ} \mathrm{O}$ valor da multa de que trata este Decreto será corrigido, periodicamente, com base nos índices estabelecidos na legislação pertinente, sendo o mínimo de $\mathrm{R} \$ 50,00$ (cinquenta reais) e o máximo de $\mathrm{R} \$ 50.000 .000,00$ (cinquenta milhões de reais)" (BRASIL. Decreto $\mathrm{n}^{\circ}$ 6.514, de 22 de julho de 2008. Disponível em: <http://www.planalto.gov.br/ccivil_03/_ato20072010/2008/decreto/D6514.htm>. Acesso em: 31 março 2014).

133 BRASIL. Lei $\mathrm{n}^{\mathrm{0}} 6.938$ de 31 de agosto de 1981. Disponível em: $<$ http://www.planalto.gov.br/ccivil_03/leis/16938.htm>. Acesso em: 31 março 2014.

134 BRASIL. Lei $\mathrm{n}^{\circ} 9 . \overline{605}$, de 12 de fevereiro de 1998. Disponível em: $<$ http://www.planalto.gov.br/ccivil_03/leis/19605.htm>. Acesso em: 31 março 2014.

135 BRASIL. Decreto $\mathrm{n}^{\mathrm{o}}-6.514$, de 22 de julho de 2008. Disponível em: <http://www.planalto.gov.br/ccivil_03/_ato2007-2010/2008/decreto/D6514.htm>. Acesso em: 31 março 2014.

136 BRASIL. Constituição Federal (1988). Disponível em: <http://www.planalto.gov.br/ccivil_03/constituicao/constituicao.htm>. Acesso em: 31 março 2014.
} 
Além de trazer poucos benefícios à sociedade e ao meio ambiente, as penas tradicionais do sistema de responsabilidade ambiental não são suficientes para inibir a prática de novos delitos. Exemplo disso é o fato de que, embora o IBAMA tenha lavrado multas em quantias cada vez maiores, o desmatamento das florestas brasileiras continua em níveis inaceitáveis.

Em 2013, foi criado o Gabinete Permanente de Gestão Integrada para a Proteção do Meio Ambiente (GGI), formado por 14 órgãos públicos, inclusive o Exército e a Força Nacional de Segurança Pública. O grupo executou duas operações de prevenção e combate ao desmatamento: "Onda Verde" e "Hileia Pátria". Juntas, as operações resultaram em R\$ 1,9 bilhão em multas, embargo de 210,2 mil hectares de terras e na apreensão de $117 \mathrm{mil} \mathrm{m}^{3}$ de madeira serrada e 68,6 mil toras, além de fechar serrarias, confiscar tratores e até armas de fogo. Todavia, entre agosto de 2012 e julho de 2013, o desmatamento cresceu $35 \%{ }^{137}$.

Sobre o corte ilegal da madeira, Peter H. May registra:

\begin{abstract}
A aplicação de mecanismos de regulamentação e sanções, por meio dos chamados Instrumentos de Comando e Controle (...) tem sido criticada por necessitar de um pesado aparelho administrativo e de capacidade de monitoração. Numa região de grande isolamento, como é o caso da Amazônia, o controle adequado de atividades econômicas, por meio de regulamentos e sanções legais, tem se mostrado ineficaz, a exemplo da extração ilegal da madeira $^{138}$.
\end{abstract}

E o problema não se restringe às técnicas adotadas pelo IBAMA. A CETESB tem envidado esforços, há décadas, para controlar a contaminação do solo e das águas no Estado de São Paulo, mas os números de infrações não reduzem. Ao contrário, as áreas contaminadas só aumentam.

\footnotetext{
137 Disponível em: <http://www.mma.gov.br/informma/item/9607-ibama-divulga-dados-sobre-alertas-dedesmatamento $>$. Acesso em: 31 março 2014.

${ }^{138}$ MAY, Peter H. Introdução. In: MAY, Peter H.; AMARAL, Carlos; MILLIKAN, Brent; ASCHER, Petra (Orgs.). Instrumentos econômicos para o desenvolvimento sustentável da Amazônia brasileira. Brasília: Ministério do Meio Ambiente, $2005 . \quad$ Disponível em: $<$ http://www.mma.gov.br/estruturas/168/_publicacao/168_publicacao30012009115059.pdf>. Acesso em: 31 março 2014.
} 
De acordo com o relatório denominado "Texto Explicativo - Relação de áreas

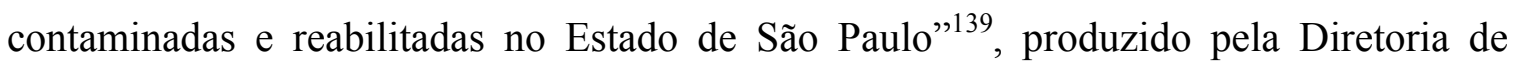
Controle e Licenciamento Ambiental da CETESB, em maio de 2002, estavam registradas 255 áreas contaminadas no Estado. Em dezembro de 2012, este número havia saltado para 4.572 , um aumento de $1.792 \%$.

Embora o aumento do registro de áreas contaminadas deva-se, em partes, ao trabalho de catalogação da CETESB, é inquestionável que a atuação repressiva dos órgãos ambientais não tem sido suficiente para reduzir as práticas de contaminação.

Frente ao exposto, considerando que as penas tradicionais do sistema de responsabilidade ambiental não são suficientes para inibir a prática de novos delitos, é necessária a adoção de medidas de estímulos a práticas saudáveis ao meio ambiente.

\subsection{A Lei de Crimes Ambientais ${ }^{140}$}

A Lei $n^{\circ} 9.605 / 1998^{141}$ merece um tópico especial, seja pela peculiaridade das penas previstas, seja pela dificuldade que o sistema jurídico brasileiro tem enfrentado para aplicá-la.

A lei registrou um marco na história legislativa brasileira, prevendo, de forma pioneira, a responsabilização penal da pessoa jurídica. Estabeleceu, também, (i) a inclusão de tipos culposos; (ii) a criação de penas restritivas de direito, fato que fortalece o papel dos implementadores da legislação ambiental (Ministério Público, órgãos ambientais fiscalizadores, Polícia, Poder Judiciário) e (iii) a reparação do dano como requisito para o reconhecimento da extinção da punibilidade, nos casos de suspensão da pena e para a concessão da transação penal.

\footnotetext{
$139 \quad$ Disponível em: <http://www.cetesb.sp.gov.br/userfiles/file/areas-contaminadas/2012/textoexplicativo.pdf $>$. Acesso em: 31 março 2014.

${ }^{140}$ Cf. comentários do autor desta Dissertação à Lei no 9.605/1998 em: MARINHO, Yuri Rugai. A lei de crimes ambientais frente à evolução do direito ambiental: sanções versus incentivos. In: ALVAREZ, Albino Rodrigues; MOTA, José Aroudo (Orgs.). Sustentabilidade ambiental no Brasil: biodiversidade, economia e bem-estar humano. Brasília: IPEA, 2010, p. 227-245.

141 BRASIL. Lei $\mathrm{n}^{\mathrm{o}} 9.605$, de 12 de fevereiro de 1998. Disponível em: $<$ http://www.planalto.gov.br/ccivil_03/leis/19605.htm>. Acesso em: 31 março 2014.
} 
Por esses e outros motivos, foi alvo de severas críticas de uma parte da doutrina, enquanto foi festejada por outra parcela dos aplicadores do Direito.

Independentemente das manifestações, fossem contrárias ou favoráveis, a Lei $\mathrm{n}^{\circ}$ $9.605 / 1998^{142}$ persistiu praticamente incólume, chegando aos dias atuais como o principal substrato para a responsabilização penal e administrativa. A norma conquistou os tribunais, definiu a jurisprudência e orientou a fiscalização e a punição daqueles que praticam atos potencial ou efetivamente lesivos ao meio ambiente.

\title{
Como bem ressalta Édis Milaré:
}

em todo o território nacional ecoaram manifestações e polêmicas a respeito dessa lei: o jurista e professor de Direito Penal Miguel Reale Jr., escrevendo logo após a sua edição, classificou-a como hedionda; os ambientalistas acusaram-na de tímida; e os representantes de setores por ela afetados ainda a rotulam de draconiana ${ }^{143}$.

Luiz Regis Prado também critica o legislador, o qual teria sido pródigo

\begin{abstract}
no emprego de conceitos amplos e indeterminados - permeados, em grande parte, por impropriedades lingüísticas, técnicas e lógicas -, o que contrasta com o imperativo inafastável de clareza, precisão e certeza na descrição das condutas típicas $^{144}$.
\end{abstract}

Com efeito, a falta de técnica na construção dos tipos - demasiadamente abertos - acaba por ferir, dentre outros, os princípios da legalidade, da ampla defesa e do contraditório, uma vez que dificulta a resposta do réu à acusação apresentada. Sem qualquer dúvida, a título de exemplo, torna-se hercúleo apresentar preliminares ou contestar, no mérito, uma acusação de

causar poluição de qualquer natureza em níveis tais que resultem ou possam resultar em danos à saúde humana, ou que provoquem a mortandade de animais ou a destruição significativa da flora (artigo 54 da Lei $\mathrm{n}^{\circ}$ $9.605 / 1998)^{145}$.

\footnotetext{
142 BRASIL. Lei $\mathrm{n}^{\mathrm{o}}$ 9.605, de 12 de fevereiro de 1998. Disponível em: $<$ http://www.planalto.gov.br/ccivil 03/leis/19605.htm>. Acesso em: 31 março 2014.

${ }^{143}$ MILARÉ, Édis. Direito do ambiente... cit., p. 1.001.

${ }^{144}$ PRADO, Luiz Regis. Princípios penais de garantia e a nova lei ambiental. Boletim IBCCRIM, edição especial do IV Seminário Internacional do IBCCRIM. São Paulo: IBCCRIM, n. 70, 1998, p. 10-23.

${ }^{145}$ Idem, ibidem.
} 
Para que seja definido o tipo penal, ao qual a sanção é associada, são inúmeras as dificuldades enfrentadas, a começar pela determinação da extensão do dano - o dano pode estar restrito ao local ou estender-se por várias regiões; pode prejudicar somente os animais ou alastrar-se para a flora e outros recursos naturais, por exemplo. Também é extremamente difícil a descrição da conduta antijurídica, já que diversos campos da ciência devem ser considerados - Geografia, Biologia, Climatologia, Agronomia, Física, Química etc.

Neste tom, considerou Gilberto Passos de Freitas que

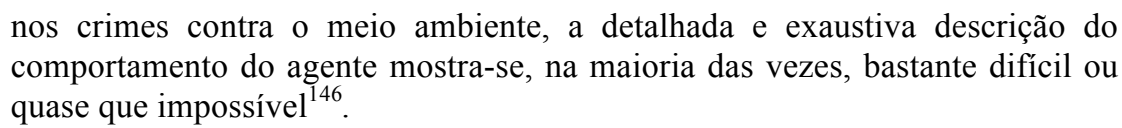

Tais dificuldades, quando transpostas ao processo (inquéritos, processos administrativos, ações judiciais em geral), causam transtornos nos órgãos de fiscalização, congestionam o Judiciário, atravancam os órgãos licenciadores e desafiam os aplicadores do Direito.

No Capítulo V da lei (artigos 29 a $69^{147}$ ), os crimes ambientais são divididos em 5 tipos: (i) contra a fauna; (ii) contra a flora; (iii) de poluição e outros crimes; (iv) contra o ordenamento urbano e o patrimônio cultural e (v) contra a administração ambiental.

Para todos esses crimes foram previstas penas privativas de liberdade, podendo ser na modalidade de reclusão ou detenção.

No Capítulo VI da lei, o artigo 70 trata das infrações administrativas, in verbis:

Art. 70. Considera-se infração administrativa ambiental toda ação ou omissão que viole as regras jurídicas de uso, gozo, promoção, proteção e recuperação do meio ambiente ${ }^{148}$.

\footnotetext{
${ }^{146}$ FREITAS, Gilberto Passos de. Direito penal ambiental. In: PHILIPPI JUNIOR, Arlindo; ALVES, Alaôr Caffé (Editores). Curso interdisciplinar de direito ambiental. Barueri: Manole, 2005, p. 403.

147 BRASIL. Lei $\mathrm{n}^{\mathrm{o}} 9.605$, de 12 de fevereiro de 1998. Disponível em: $<$ http://www.planalto.gov.br/ccivil_03/leis/19605.htm>. Acesso em: 31 março 2014.

148 BRASIL. Lei $\mathrm{n}^{\mathrm{o}} 9.605$, de 12 de fevereiro de 1998. Disponível em: $<$ http://www.planalto.gov.br/ccivil_03/leis/19605.htm>. Acesso em: 31 março 2014.
} 
Quando são analisados tais dispositivos, percebe-se quão abrangentes e abstratos são os tipos penais criados, e quão genérica é a definição de infração administrativa.

Não se deixe de mencionar que o Direito Penal é a ultima ratio em matéria de responsabilização jurídica, aplicável somente quando as demais instâncias de responsabilização já tenham sido insuficientes. O princípio da intervenção mínima do Direito Penal reconhece a liberdade como direito fundamental do homem e valor maior para a vida em sociedade, razão pela qual, somente quando for necessário ao bem jurídico tutelado, a responsabilização penal deverá ser aplicada.

Sobre a matéria, Luiz Regis Prado ensina:

\begin{abstract}
A orientação político-criminal mais acertada é a de que a intervenção penal na proteção do meio ambiente seja feita de forma limitada e cuidadosa. Não se pode olvidar jamais que se trata de matéria penal, ainda que peculiaríssima, submetida de modo inarredável, portanto, aos ditames rígidos dos princípios constitucionais penais - legalidade dos delitos e das penas, intervenção mínima e fragmentariedade, entre outros -, pilares que são do Estado de Direito democrático. A sanção penal é ultima ratio do ordenamento jurídico, devendo ser utilizada tão somente para as hipóteses de atentados graves ao bem jurídico ambiente. O Direito Penal nesse campo cinge-se, em princípio, a uma função subsidiária, auxiliar ou de garantia de preceitos administrativos, o que não exclui sua intervenção de forma direta e independente, em razão da gravidade do ataque ${ }^{149}$.
\end{abstract}

No mesmo sentido, Patrícia Faga Iglecias Lemos aponta:

\begin{abstract}
A proteção por meio do direito penal é fragmentária, vez que somente se justifica quando outros meios jurídicos (do direito civil ou do direito administrativo, por exemplo) não bastam para a proteção eficaz dos bens jurídicos. Tendo em vista que o direito penal está diretamente ligado a intervenções especialmente graves aos direitos fundamentais dos cidadãos, ele só pode ser permitido como a última instância de proteção dos bens jurídicos. Isso significa que um bem jurídico merece proteção por meio do direito penal somente nos casos em que outras medidas jurídicas não são suficientes ${ }^{150}$.
\end{abstract}

${ }^{149}$ PRADO, Luiz Regis. Crimes contra o ambiente. São Paulo: RT, 1998, p. 17.
${ }^{150}$ LEMOS, Patrícia Faga Iglecias. Direito ambiental... cit., p. 223. 
Quanto à Lei no 9.605/1998 ${ }^{151}$, Patrícia Faga Iglecias Lemos registra, citando Regis Prado, que seu advento "lamentavelmente, pouco contribuiu para o necessário aperfeiçoamento do tratamento legislativo da matéria ambiental"152.

Por tantos motivos, apesar do inegável avanço que a Lei ${ }^{0} 9.605 / 1998^{153}$ trouxe ao Direito Ambiental doméstico, inúmeras são as críticas que podem ser apontadas quanto às definições dos tipos penais, à generalidade do conceito de infração administrativa e às sanções impostas.

Uma alternativa que é proposta para alcançar uma maior eficácia da lei é a concessão de incentivos a determinados tipos de condutas, conforme será explorado adiante neste trabalho.

151 BRASIL. Lei $\mathrm{n}^{\mathrm{o}}$ 9.605, de 12 de fevereiro de 1998. Disponível em: $<$ http://www.planalto.gov.br/ccivil_03/leis/19605.htm>. Acesso em: 31 março 2014.

${ }^{152}$ LEMOS, Patrícia Faga Iglecias. Direito ambiental... cit., p. 225.

153 BRASIL. Lei $\mathrm{n}^{\mathrm{o}} 9.605$, de 12 de fevereiro de 1998. Disponível em: $<$ http://www.planalto.gov.br/ccivil_03/leis/19605.htm>. Acesso em: 31 março 2014. 


\section{CAPÍTULO 4 - O REGIME DE INCENTIVOS}

Este Capítulo destina-se a conceituar e apresentar uma visão jurídica das normas positivas, os incentivos no Direito Ambiental, para que possam ser discutidas a problemática da concessão de incentivos ambientais e a forma como a legislação e a doutrina brasileiras encaram o assunto.

\subsection{Conceito de incentivos}

O vocábulo incentivo tem sua origem do latim incentivus, e, na definição do Dicionário Brasileiro Contemporâneo, é "aquilo que excita ou estimula; estimulante (...); o que estimula"154.

Outra definição, um tanto semelhante, trazida pelo Pequeno Dicionário Brasileiro da Língua Portuguesa, revela que incentivo é aquilo "que incentiva, que excita; (...) que estimula; estímulo"

Infere-se das definições que a ideia de incentivo está intimamente ligada a estímulo, excitação. O incentivo, portanto, tem função de estimular, excitar alguma coisa. É capaz de induzir a modificação de determinada situação, podendo levar dinamicidade ao que era estático. Da mesma forma, é capaz de corrigir determinada situação de erro, desde que o estímulo seja no sentido de correção.

O emprego do termo incentivo pode dar-se nos mais variados campos da ciência e dos ramos de estudo. No âmbito do Direito, os incentivos fazem parte das denominadas sanções positivas, compondo o rol de instrumentos utilizados pelo Estado para o regramento da sociedade.

\footnotetext{
${ }^{154}$ FERNANDES, Francisco. Dicionário Brasileiro Contemporâneo. 2. ed. São Paulo: Editora Globo, 1969.

${ }^{155}$ FERREIRA, Aurélio Buarque de Hollanda. Pequeno Dicionário brasileiro da língua portuguesa. 11. ed. São Paulo: Editora Civilização Brasileira S.A., 1969.
} 


\section{Em sua obra, Hans Kelsen observa:}

conforme o modo pelo qual as ações humanas são prescritas ou proibidas, podem distinguir-se diferentes tipos - tipos ideais, não tipos médios. A ordem social pode prescrever uma determinada conduta humana sem ligar à observância ou não observância deste imperativo quaisquer consequências. Também pode, porém, estatuir uma determinada conduta humana e, simultaneamente, ligar a esta conduta a concessão de uma vantagem, de um prêmio, ou ligar à conduta oposta uma desvantagem, uma pena (no sentido mais amplo da palavra). O princípio que conduz a reagir a uma determinada conduta com um prêmio ou uma pena é o princípio retributivo (Vergeltung). O prêmio e o castigo podem compreender-se no conceito de sanção. No entanto, usualmente, designa-se por sanção somente a pena, isto é, um mal - a privação de certos bens como a vida, a saúde, a liberdade, a honra, valores econômicos a aplicar como consequência de uma determinada conduta, mas já não o prêmio ou a recompensa ${ }^{156}$.

O autor ensina, pelo exposto, que há duas opções para o regramento das condutas: (i) punição para a conduta indesejada e (ii) incentivo à conduta desejada.

Como já demonstrado no Capítulo 1, o Estado contemporâneo tem deixado sua função garantista e repressora para desenvolver um papel dirigista, para o fim de direção social mediante previsão de sanções positivas (estímulos).

\section{Terence Dorneles Trennepohl registra que}

as tendências apontam para o prêmio como valorização do correto e não para a deformada visão do ilícito como jurídico, e da sanção repressiva como solução para os conflitos ${ }^{157}$.

E complementa:

(...) a punição, através da aplicação da sanção negativa, representando castigo e represália, mostra-se, no mundo contemporâneo, em flagrante decadência, seja pela falência das instituições punitivas, seja pela ineficácia da tão pretendida ressocialização, pelas vias da prisão ou das penas restritivas de direitos. As tendências mais modernas de descriminalização buscam a aplicação do Direito Penal Mínimo e a alternatividade das penas aplicadas ${ }^{158}$.

\footnotetext{
${ }^{156}$ KELSEN, Hans. Op. cit., p. 26.

${ }^{157}$ TRENNEPOHL, Terence Dorneles. Op. cit., p. 41.

${ }^{158}$ Idem, ibidem.
} 
$\mathrm{Na}$ University of Southern California, Michael S. Knoll ${ }^{159}$ questiona a eficácia da imposição isolada de penalidades, principalmente em relação à aplicação de multas em valores vultosos, uma vez que, como já estudado por respeitados nomes do Direito e da Economia, o efeito de tal imposição pode ser perverso.

Michael S. Knoll ensina que um racional tomador de decisão ${ }^{160}$, diante de uma situação em que deve decidir pela continuidade da produção de um produto que pode ser perigoso, não vai deixar de produzir se a aplicação de uma multa implicar sua falência. Ou seja, como o pagamento da multa significaria o fim de suas atividades, esse tomador de decisão prefere correr o risco de operar irregularmente até a eventual autuação, em vez de considerar o pagamento da multa, a adequação às normas e a continuidade de suas atividades ${ }^{161}$. Trata-se do denominado efeito perverso ${ }^{162}$.

Daí se diga que a previsão de penalidades desproporcionais às empresas poluidoras ou que representem risco ao homem e ao ambiente podem causar um efeito contrário ao esperado, resultando em clandestinidade e, por consequência, prejuízos sociais, ambientais, fiscais, trabalhistas, dentre tantos outros.

É certo que o Direito deve trazer normas punitivas, seja para fins educativos, seja para fins de repressão a condutas indesejáveis. Todavia, esse tipo de instrumento não deve trazer punições exageradas, pelos motivos supra citados.

Da mesma forma, as sanções negativas não devem ser o único meio utilizado, principalmente nos casos de difícil reparação dos danos, tal como ocorre nas questões ambientais.

\footnotetext{
${ }^{159}$ KNOLL, Michael S. Products liability and legal leverage. The perverse effect of stiff penalties, UCLA University of California Los Angeles - Law Review, v. 45, number 1, October 1997, p. 101.

${ }^{160}$ Tradução livre do autor desta Dissertação. Do original: "rational decisionmaker". Idem, ibidem.

${ }^{161}$ Tradução livre do autor desta Dissertação. Do original: "When faced with a decision whether to continue producing a product that might be dangerous, a rational decisionmaker will compare its expected wealth if it continues production with its expected wealth if it ceases production. Once penalties are stiff enough that the decisionmaker will be bankrupt if it continues production and is held liable, further increasing liability awards will have no effect on its expected wealth if production continues. However, if the manufacturer would not be bankrupt if it ceased production and is held liable, then further increasing liability awards will reduce its expected wealth if production ceases. In this range, the cost to the decisionmaker of continuing production decreases as liability awards increase. As a result, the decisiomaker might continue to produce a potentially dangerous product that it would have stopped producing if liability awards were smaller. This is the 'perverse effect'”. Idem, ibidem.

${ }^{162}$ Tradução livre do autor desta Dissertação. Do original: "perverse effect”. Idem, ibidem.
} 
O sistema jurídico pode focar em normas protetivo-repressivas ou em normas promocionais, sejam elas de caráter positivo ou negativo. No primeiro caso, três modos de impedir uma ação podem ser utilizados: torná-la impossível, torná-la difícil ou torná-la desvantajosa. Por outro lado, o sistema promocional busca atingir os mesmos fins por três operações contrárias, quais sejam, tornar a ação desejada necessária, torná-la fácil ou torná-la vantajosa.

O Direito é capaz de direcionar a sociedade pelo uso de incentivos, de forma a promover a realização de atos socialmente desejáveis. A função estatal deixa de ser exclusivamente protetora e repressiva, passando a assumir papel também promocional.

A sanção positiva pode constituir tanto na atribuição de uma vantagem quanto na privação de uma desvantagem. Há sanções que consistem em um bem econômico (compensações em dinheiro ou propriedades), um bem social (concessão de status), um bem moral (honrarias) ou um bem jurídico (privilégios).

Em uma comparação muito simplista em relação às sanções negativas, pode-se dizer que a sanção positiva é uma reação a uma ação boa, enquanto a sanção negativa é uma reação a uma ação má. No primeiro caso, restitui-se o bem ao bem; no segundo, o mal ao mal.

A sanção positiva pode assumir função retributiva, na forma de uma reação favorável a um comportamento vantajoso para a sociedade, ou função compensatória ou indenizatória, na forma de compensação ao agente pelos esforços, pelas dificuldades enfrentadas, pelas despesas assumidas e pelos benefícios que trouxe à sociedade.

\subsection{Tipos de incentivos}

Como tratado no Capítulo 2, os incentivos são instrumentos utilizados pelo modelo de Estado promocional, como técnica de encorajamento. O ordenamento promocional busca atingir seus fins buscando tornar uma ação desejada necessária, fácil ou vantajosa. 
Para tanto, cria comandos ou proibições reforçados por prêmios. Quando a atuação do ordenamento é prévia em relação à conduta, buscará facilitar o comportamento esperado; se for posterior, buscará atribuir consequências agradáveis.

Importante notar que os incentivos podem assumir diferentes formas e naturezas, tais como norma jurídica, procedimento, prestação de serviço, produto etc. Serão normas sempre que for editada uma lei, decreto, portaria, resolução ou outra forma de texto que crie ou regulamente um incentivo para determinada prática, de maneira válida perante o sistema jurídico.

Os incentivos podem assumir a forma de procedimento, a exemplo do que ocorreria na concessão de facilidades na obtenção de empréstimos financeiros, ou seja, um procedimento interno da entidade financeira.

Podem, também, ocorrer na forma de prestação de serviço, como no caso de fornecimento de estradas e máquinas, ou quaisquer outros serviços públicos a determinada comunidade que contribua com a manutenção da qualidade do meio ambiente.

Os incentivos ainda podem assumir a forma de produto, como no caso dos instrumentos de mercado criados por entidades de natureza pública ou privada. Títulos representativos de uma conduta pró-ambiente, a exemplo da manutenção de vegetação, quando comercializados, podem criar incentivos para aqueles que desejam preservar a natureza auferindo renda.

$\mathrm{Ou}$ seja, os incentivos podem ocorrer em numerosas situações e assumir diferentes formas ${ }^{163}$. Para que o emprego do termo incentivo ambiental possa ser

\footnotetext{
${ }^{163} \mathrm{O}$ autor norte-americano Myrick Freeman III cita a imposição de taxas em atividades poluentes como uma forma de estímulo a atividades favoráveis ao meio ambiente. Segundo ele, tal estratégia inclui a poluição como um custo de produção, o que estimula o empreendedor a reduzi-la a níveis próximos de zero. Além disso, estimula inovações e mudanças tecnológicas no controle da poluição. Tradução livre do autor desta Dissertação. Do original: "The pollution tax (or charge) strategy has long appealed to economists because it provides a sure and graduated incentive to firms by making pollution itself a cost of production. And it provides an incentive for innovation and technological change in pollution control" (FREEMAN III, A. Myrick. Op. cit., p. 201).
} 
utilizado corretamente no presente trabalho, consideraremos a sua definição aberta, no sentido de representar um estímulo a uma prática favorável ao meio ambiente.

É importante apenas notar que os incentivos podem ser divididos em prévios e posteriores em relação à conduta desejada, divisão essa que facilita a sua compreensão e utilização no campo do Direito Ambiental.

São exemplos de incentivos prévios: (i) redução do encargo tributário; (ii) redução dos procedimentos burocráticos de regularização da propriedade; (iii) concessão de facilidades na obtenção de empréstimos financeiros; (iv) fornecimento de serviços públicos e (v) disponibilização de tecnologia.

Como incentivos posteriores à conduta desejada, podem ser citados: (i) o pagamento por serviços ambientais; (ii) criação de lista ou ranking das pessoas com boas práticas ambientais e (iii) criação de instrumentos de mercado.

As modalidades de incentivos supracitadas são apenas exemplos e estão focadas na realidade brasileira, de forma que outros instrumentos podem ser utilizados, tais como subsídios, instituição de taxas e encargos etc. A exemplificação de tais modalidades não busca exaurir todas as formas de incentivos ambientais que possam existir ou serem implantadas no Brasil, servindo apenas para ilustrar alguns exemplos existentes no momento da preparação do presente trabalho.

As modalidades de incentivos podem envolver, ou não, a transferência direta de recursos financeiros. Nos casos em que há transferência, alguns cuidados devem ser tomados, a fim de evitar desvio de dinheiro e corrupção. É preciso assegurar que o montante destinado ao beneficiário seja efetiva e diretamente transferido (por exemplo, mediante depósito direto em conta corrente).

Além disso, é importante que não haja "intermediários" na transferência de recursos, nem tampouco critérios subjetivos para o simples pagamento, o que demandaria a análise de uma autoridade e, consequentemente, criaria um risco de desvio. 


\title{
4.2.1 Redução do encargo tributário
}

É ampla a discussão sobre o emprego de instrumentos tributários para a indução de práticas favoráveis ao meio ambiente. Luís Eduardo Schoueri ${ }^{164}$ comenta que se chegou até a cogitar um tributo calculado sobre o volume de emissões.

Segundo ele, para a introdução de tal tributo, deveria o Estado fixar um objetivo de emissão para cada elemento poluente, estimando os custos para evitar que tal limite fosse ultrapassado e fixando o tributo em valor equivalente a tais custos.

Luís Eduardo Schoueri anota:

\begin{abstract}
Acreditava-se que, do ponto de vista macroeconômico, o tributo teria a seu favor a maior eficiência, já que cada emitente buscaria pagar o menor tributo possível, além de promover o desenvolvimento técnico, já que o emitente não se satisfaria em atingir limites predeterminados. O tributo serviria, assim, de mecanismo para internalizar os custos ambientais, gerando o que Gawel denomina uma correção na alocação (Allokationskorrektur), que ele apresenta como uma mudança comportamental no emprego de bens ambientais, sendo tal objetivo alcançado mediante uma absorção dirigida de recursos no setor privado $^{165}$.
\end{abstract}

A tributação de atividades poluentes pode ser apontada por alguns autores como uma forma de incentivo a atividades favoráveis ao meio ambiente. Todavia, acreditamos que existem limites para a "agressividade" do legislador tributário, seja para a proteção dos princípios de direito (legalidade, igualdade, razoabilidade, proporcionalidade, capacidade contributiva etc.), seja para evitar o efeito de confisco. Por isso, entendemos ser preferível a redução de tributos para práticas saudáveis em vez do aumento para atividades danosas.

A Lei $n^{0} 12.187 / 2009^{166}$, que institui a Política Nacional sobre Mudança do Clima, estabelece, em seu artigo $6^{\circ}$, inciso $\mathrm{VI}^{167}$, alíquotas diferenciadas, isenções,

\footnotetext{
${ }^{164}$ SCHOUERI, Luís Eduardo. Normas tributárias indutoras em matéria ambiental. In: TORRES, Heleno Taveira (Org.). Direito tributário ambiental. São Paulo: Malheiros, 2005, p. 238.

${ }^{165}$ Idem, ibidem.

166 BRASIL. Lei $\mathrm{n}^{\mathrm{o}}$ 12.187, de 29 de dezembro de 2009. Disponível em: $<$ http://www.planalto.gov.br/ccivil_03/_ato2007-2010/2009/lei/112187.htm>. Acesso em: 31 março 2014.

${ }^{167}$ Cf. artigo $6^{\circ}$ da Lei n ${ }^{\circ} 12.187 / 2009$. "Art. $6^{\circ}$ São instrumentos da Política Nacional sobre Mudança do Clima: (...) VI - as medidas fiscais e tributárias destinadas a estimular a redução das emissões e remoção de gases de efeito estufa, incluindo alíquotas diferenciadas, isenções, compensações e incentivos, a serem
} 
compensações e incentivos como instrumentos para estimular a redução das emissões e remoção de gases de efeito estufa.

No mesmo sentido, a Lei $\mathrm{n}^{\mathrm{o}} 12.305 / 2010^{168}$ estabelece como instrumentos da Política Nacional de Resíduos Sólidos os incentivos fiscais, financeiros e creditícios (artigo $8^{\circ}$, inciso IX $\left.{ }^{169}\right)$.

Por sua vez, a Lei $\mathrm{n}^{\mathrm{0}} 11.196 / 2005^{170}$ prevê incentivos fiscais à pessoa jurídica que produzir inovação tecnológica, o que inclui deduções, redução de Imposto sobre Produtos Industrializados (IPI), depreciação integral de máquinas no próprio ano de aquisição, amortização acelerada e redução da alíquota do imposto de renda (artigo $\left.17^{171}\right)$.

Em geral, como já observado por muitos dos aplicadores do Direito, as normas de incentivo fiscal são mais aceitas e recebidas do que as sanções negativas, pois estão estatuídas sob os pilares da intervenção estatal no domínio econômico, por meio da extrafiscalidade, inerente à tributação moderna. São exemplos: isenções, imunidades,

estabelecidos em lei específica (...)" (BRASIL. Lei no 12.187, de 29 de dezembro de 2009. Disponível em: $<$ http://www.planalto.gov.br/ccivil_03/_ato2007-2010/2009/lei/112187.htm>. Acesso em: 31 março 2014).

168 BRASIL. Lei $\mathrm{n}^{\mathrm{o}} 1 \overline{2} .30 \overline{5}$, de 2 de agosto de 2010. Disponível em: $<$ http://www.planalto.gov.br/ccivil_03/_ato2007-2010/2010/lei/112305.htm>. Acesso em: 31 março 2014.

${ }^{169}$ Cf. artigo $8^{\circ}$ da Lei $n^{\circ} 12.305 / 2010$. “Art. $8^{\circ}$ São instrumentos da Política Nacional de Resíduos Sólidos, entre outros: (...) IX - os incentivos fiscais, financeiros e creditícios (...)” (BRASIL. Lei no 12.305, de 2 de agosto de 2010. Disponível em: <http://www.planalto.gov.br/ccivil_03/_ato20072010/2010/lei/112305.htm>. Acesso em: 31 março 2014).

170 BRASIL. Lei $\mathrm{n}^{\mathrm{o}} 11.196$, de 21 de novembro de 2005. Disponível em: $<$ http://www.planalto.gov.br/ccivil_03/_ato2004-2006/2005/lei/111196.htm>. Acesso em: 31 março 2014.

${ }^{171}$ Cf. artigo 17 da Lei no 11.196/2005. "Art. 17. A pessoa jurídica poderá usufruir dos seguintes incentivos fiscais: I - dedução, para efeito de apuração do lucro líquido, de valor correspondente à soma dos dispêndios realizados no período de apuração com pesquisa tecnológica e desenvolvimento de inovação tecnológica classificáveis como despesas operacionais pela legislação do Imposto sobre a Renda da Pessoa Jurídica - IRPJ ou como pagamento na forma prevista no $\S 2^{\circ}$ deste artigo; II - redução de 50\% (cinquenta por cento) do Imposto sobre Produtos Industrializados - IPI incidente sobre equipamentos, máquinas, aparelhos e instrumentos, bem como os acessórios sobressalentes e ferramentas que acompanhem esses bens, destinados à pesquisa e ao desenvolvimento tecnológico; III - depreciação integral, no próprio ano da aquisição, de máquinas, equipamentos, aparelhos e instrumentos, novos, destinados à utilização nas atividades de pesquisa tecnológica e desenvolvimento de inovação tecnológica, para efeito de apuração do IRPJ e da CSLL; IV - amortização acelerada, mediante dedução como custo ou despesa operacional, no período de apuração em que forem efetuados, dos dispêndios relativos à aquisição de bens intangíveis, vinculados exclusivamente às atividades de pesquisa tecnológica e desenvolvimento de inovação tecnológica, classificáveis no ativo diferido do beneficiário, para efeito de apuração do IRPJ; V (Revogado). VI - redução a 0 (zero) da alíquota do imposto de renda retido na fonte nas remessas efetuadas para o exterior destinadas ao registro e manutenção de marcas, patentes e cultivares" (BRASIL. Lei $\mathrm{n}^{\circ}$ 11.196, de 21 de novembro de 2005. Disponível em: <http://www.planalto.gov.br/ccivil_03/_ato20042006/2005/lei/111196.htm>. Acesso em: 31 março 2014). 
alíquotas zero ou reduzidas, redução da base de cálculo, bonificações, reduções, subsídios, subvenções etc.

\subsubsection{Redução dos procedimentos burocráticos de regularização da propriedade}

A manutenção da regularidade de uma propriedade exige uma série de cuidados do proprietário. A extensa legislação ambiental, urbanística e agrária cria obrigações que, muitas vezes, são incompreensíveis ao cidadão comum, o que dificulta o seu cumprimento e exige a contratação de profissionais para assessoria técnica e jurídica.

Todavia, nem todos os proprietários têm recursos suficientes para contratar assessoria, o que resulta, invariavelmente, em uma situação de inadimplência à legislação. O pequeno proprietário rural, por exemplo, tem dificuldades não só para acessar e compreender as leis, decretos, portarias e resoluções do complexo ordenamento jurídico brasileiro, mas também para encontrar e contratar prestadores de serviços que possam interpretar tais normas. Não é raro, portanto, que esse pequeno proprietário rural cometa infrações ambientais pelo simples desconhecimento de suas obrigações legais.

Para estimular a manutenção da regularidade das propriedades ou mesmo proceder à regularização dos inadimplentes, é possível estabelecer procedimentos menos burocráticos, mais acessíveis e mais céleres àqueles que tenham práticas favoráveis ao meio ambiente. Com isso, reconhece-se o importante papel desses proprietários, ao mesmo tempo em que se aumenta o número de propriedades regulares.

Da mesma forma, é possível que instituições públicas disponibilizem pontos de assistência e profissionais com conhecimento jurídico e técnico, a fim de assessorar os particulares no atendimento de suas obrigações. 
O governo federal brasileiro criou uma política de apoio à regularização ambiental visando a aumentar o número de propriedades regularizadas no território nacional. Trata-se do Cadastro Ambiental Rural (CAR), instituído pela Lei $\mathrm{n}^{\mathrm{o}}$ $12.651 / 2012^{172}$.

Como apontado pelo Ministério do Meio Ambiente, trata-se de um "instrumento fundamental para auxiliar no processo de regularização ambiental de propriedades e posses rurais" $" 173$.

\subsubsection{Concessão de facilidades na obtenção de empréstimos financeiros}

Um dos requisitos para a concessão de empréstimos pelas entidades financeiras é a demonstração da completa regularidade do empreendimento ou do imóvel a que se destinam os recursos. Para os casos em que há risco de dano ambiental, é comum que os juros cobrados sejam elevados, a fim de compensar o risco assumido pela entidade financeira.

\footnotetext{
${ }^{172}$ Cf. artigo 29 da Lei no 12.651/2012. "Art. 29. É criado o Cadastro Ambiental Rural - CAR, no âmbito do Sistema Nacional de Informação sobre Meio Ambiente - SINIMA, registro público eletrônico de âmbito nacional, obrigatório para todos os imóveis rurais, com a finalidade de integrar as informações ambientais das propriedades e posses rurais, compondo base de dados para controle, monitoramento, planejamento ambiental e econômico e combate ao desmatamento. $\S 1^{\circ}$ A inscrição do imóvel rural no CAR deverá ser feita, preferencialmente, no órgão ambiental municipal ou estadual, que, nos termos do regulamento, exigirá do proprietário ou possuidor rural: I - identificação do proprietário ou possuidor rural; II comprovação da propriedade ou posse; III - identificação do imóvel por meio de planta e memorial descritivo, contendo a indicação das coordenadas geográficas com pelo menos um ponto de amarração do perímetro do imóvel, informando a localização dos remanescentes de vegetação nativa, das Áreas de Preservação Permanente, das Áreas de Uso Restrito, das áreas consolidadas e, caso existente, também da localização da Reserva Legal. $\S 2^{\circ} \mathrm{O}$ cadastramento não será considerado título para fins de reconhecimento do direito de propriedade ou posse, tampouco elimina a necessidade de cumprimento do disposto no art. $2^{\circ}$ da Lei $\mathrm{n}^{\circ} 10.267$, de 28 de agosto de 2001 . $\S 3^{\circ} \mathrm{A}$ inscrição no CAR será obrigatória para todas as propriedades e posses rurais, devendo ser requerida no prazo de 1 (um) ano contado da sua implantação, prorrogável, uma única vez, por igual período por ato do Chefe do Poder Executivo". (BRASIL. Lei n ${ }^{\circ}$ 12.651 , de 25 de maio de 2012. Disponível em: <http://www.planalto.gov.br/ccivil_03/_ato20112014/2012/lei/112651.htm>. Acesso em: 31 março 2014).

${ }^{173}$ Disponível em: <http://www.mma.gov.br/desenvolvimento-rural/cadastro-ambiental-rural $>$. Acesso em: 31 março 2014. Sobre o CAR, o Ministério do Meio Ambiente ainda destaca em seu sítio eletrônico: "Consiste no levantamento de informações georreferenciadas do imóvel, com delimitação das Áreas de Proteção Permanente (APP), Reserva Legal (RL), remanescentes de vegetação nativa, área rural consolidada, áreas de interesse social e de utilidade pública, com o objetivo de traçar um mapa digital a partir do qual são calculados os valores das áreas para diagnóstico ambiental”.
} 
Tal situação restringe o fornecimento de crédito e, consequentemente, o desenvolvimento de atividades que poderiam trazer um ganho ambiental.

Se fossem concedidas facilidades na obtenção de empréstimos para pessoas ou empresas que tenham práticas positivas ao meio ambiente, e se tais recursos fossem aplicados no desenvolvimento de novas atividades com efeito ambiental positivo, haveria um importante ganho ambiental.

As entidades financeiras poderiam priorizar ou conceder taxas reduzidas de juros, dentre outras medidas de facilitação, para atividades com essas características, até porque o seu risco seria, muito provavelmente, menor. Esse tipo de incentivo poderá vir a ser uma regra nos financiamentos públicos.

Quanto ao tema, a Lei da Mata Atlântica (Lei no $11.428 / 2006^{174}$ ) prevê, no artigo 41 , inciso $\mathrm{I}^{175}$, prioridade na concessão de crédito agrícola para pequenos produtores rurais e populações tradicionais que tenham vegetação primária ou secundária em estágios avançado e médio de regeneração do Bioma Mata Atlântica.

No mesmo sentido, tal como já apontado, o artigo $8^{\circ}$ da Lei $n^{\circ} 12.305 / 2010^{176}$ prevê incentivos financeiros e creditícios como instrumentos da Política Nacional de Resíduos Sólidos ${ }^{177}$.

Werner Grau Neto aponta que o setor financeiro já desenvolveu um sistema de estímulo de atividades econômicas a partir do interesse da sustentabilidade:

\footnotetext{
174 BRASIL. Lei $\mathrm{n}^{\mathrm{o}}$ 11.428, de 22 de dezembro de 2006. Disponível em: $<$ http://www.planalto.gov.br/ccivil_03/_ato2004-2006/2006/lei/111428.htm>. Acesso em: 31 março 2014.

${ }^{175} \mathrm{Cf}$. artigo 41 da Lei $\mathrm{n}^{\circ} 11.428 / 2006$. "Art. 41. O proprietário ou posseiro que tenha vegetação primária ou secundária em estágios avançado e médio de regeneração do Bioma Mata Atlântica receberá das instituições financeiras benefícios creditícios, entre os quais: I - prioridade na concessão de crédito agrícola, para os pequenos produtores rurais e populações tradicionais (...)" (BRASIL. Lei n ${ }^{\circ} 11.428$, de 22 de dezembro de 2006. Disponível em: <http://www.planalto.gov.br/ccivil_03/_ato20042006/2006/lei/111428.htm>. Acesso em: 31 março 2014).

176 BRASIL. Lei $\mathrm{n}^{\mathrm{o}}$ 12.305, de 2 de agosto de 2010. Disponível em: $<$ http://www.planalto.gov.br/ccivil_03/_ato2007-2010/2010/lei/112305.htm>. Acesso em: 31 março 2014.

${ }^{177}$ Cf. artigo $8^{\circ}$ da Lei $n^{\circ} 12.305 / 2010$. “Art. $8^{\circ}$ São instrumentos da Política Nacional de Resíduos Sólidos, entre outros: (...) IX - os incentivos fiscais, financeiros e creditícios (...)” (BRASIL. Lei $\mathrm{n}^{\circ} 12.305$, de 2 de agosto de 2010. Disponível em: <http://www.planalto.gov.br/ccivil_03/_ato20072010/2010/lei/112305.htm>. Acesso em: 31 março 2014).
} 
Com efeito, o setor financeiro já desenvolveu sistema em tudo interessante ao que aqui buscamos: trata-se dos Princípios do Equador, protocolo e regras e valores adotado por grupo de instituições financeiras de vários países, por meio do qual se estabelece condições ao financiamento de atividades produtivas de potencial degradador, garantindo assim critérios de controle e proteção ambiental que excedem os parâmetros legais.

Tal sistema opera de acordo com três planos essenciais: exclusões, salvaguardas e induções. Nega-se financiamento às atividades que, segundo determinados critérios, revelam-se por demais potencialmente degradadoras do meio ambiente. Impõem-se exigências ao financiamento de outras atividades que, em que pese degradadoras, admitem controles se aplicados determinados cuidados essenciais, e se concede financiamento a taxas atrativas a atividades havidas como dotadas de postura especialmente positiva sob a ótica ambiental $^{178}$.

\subsubsection{Fornecimento de serviços públicos}

A manutenção de uma propriedade ou a condução de uma atividade econômica envolve muitos gastos e investimentos. Deixando-se um pouco de lado as diferenças técnicas entre gastos e investimentos, e considerando-os conjuntamente como custos, é notório que as obrigações de cunho ambiental exigem aporte de dinheiro.

Aos custos para cumprir obrigações ambientais, somem-se, também, os valores para cumprir as demais obrigações trazidas pela legislação brasileira.

Apenas a título de exemplo, a obrigação de realizar o gerenciamento de resíduos sólidos de uma atividade econômica e promover a sua destinação ambientalmente adequada envolve procedimentos de armazenamento, tratamento, transporte e destinação final, o que, muitas vezes, é realizado mediante contratação de empresas especializadas. Os valores necessários para esse gerenciamento são consideravelmente superiores, por exemplo, ao simples descarte irregular (o que, infelizmente, ainda é uma prática comum no Brasil $\left.{ }^{179}\right)$.

Para que as empresas que adotem práticas saudáveis ao meio ambiente sejam competitivas, é importante que seus custos sejam reduzidos.

\footnotetext{
${ }^{178}$ GRAU NETO, Werner. Op. cit., p. 25.

${ }^{179}$ De acordo com o Comunicado n ${ }^{\circ} 145$ do Instituto de Pesquisa Econômica Aplicada (IPEA), atualmente, 74 mil toneladas por dia de resíduos e rejeitos estão sendo dispostos em aterros controlados e lixões. Há 2.906 lixões que devem ser erradicados no Brasil, distribuídos em 2.810 municípios. Disponível em: $<$ http://www.ipea.gov.br/portal/images/stories/PDFs/comunicado/120425_comunicadoipea0145.pdf $>$. Acesso em: 31 março 2014.
} 
Os pequenos proprietários ou posseiros têm uma dificuldade ainda maior, considerando a escassez de seus recursos financeiros. Não é raro, no contexto brasileiro, uma família rural dividir uma renda próxima do salário mínimo para sua subsistência. De acordo com o Instituto Brasileiro de Geografia e Estatística (IBGE), a renda média nas áreas rurais era de, aproximadamente, $\mathrm{R} \$ 170,00$, em $2010^{180}$.

Com renda tão baixa, é pouco provável que o proprietário ou o posseiro terá condições de utilizar as técnicas mais avançadas e menos impactantes, sob o ponto de vista ambiental. Em alguns casos, vale dizer, seria possível a aplicação de uma técnica de produção menos impactante, mas o produtor simplesmente a desconhece por ignorância técnica.

Se esses pequenos proprietários ou possuidores pudessem ter acesso a informações e a uma infraestrutura mínima, desde que sua renda não reduzisse, certamente adotariam técnicas mais benéficas ao meio ambiente. Tais informações e infraestrutura englobam, por exemplo, o oferecimento de cursos de capacitação técnica, escolas, hospitais, ferramentas, transporte, comunicação etc.

Em suma, pessoas físicas ou jurídicas necessitam de serviços mínimos para que possam adotar práticas mais saudáveis ao meio ambiente. Para tais tipos de serviços, a doutrina utiliza o termo serviços públicos.

Quanto ao tema, João Eduardo Lopes Queiroz e Márcia Walquiria Batista dos Santos ensinam:

É permitido dizer que determinadas atividades econômicas são declaradas por lei como 'serviço público'. Isso ocorre devido à necessidade de se imporem as características de serviço público a essas atividades. Tais características - de regularidade, continuidade, eficiência, segurança, atualidade, generalidade, cortesia na sua prestação e modicidade nas suas tarifas - são as necessárias para a prestação de um serviço adequado, como deve ser todo serviço público. $\mathrm{Na}$ verdade, o Estado determina que essas atividades sejam serviços públicos por vários motivos, mas principalmente por configurarem uma necessidade

\footnotetext{
${ }^{180}$ Disponível em:

$<$ http://saladeimprensa.ibge.gov.br/noticias?view=noticia\&id=1\&busca=1\&idnoticia=2019>. Acesso em: 31 março 2014.
} 
imprescindível do conjunto social e por estarem sendo desenvolvidas em condições monopólicas ${ }^{181}$.

Ou seja, em atendimento às necessidades do conjunto social, devem ser prestados os serviços públicos com regularidade, continuidade, eficiência, segurança, atualidade, generalidade, cortesia na sua prestação e modicidade nas suas tarifas.

João Eduardo Lopes Queiroz e Márcia Walquiria Batista dos Santos ainda apontam que as funções administrativo-econômicas do setor público visam promover e induzir o desenvolvimento do País. Para tanto, apontam como importante instrumento os estímulos positivos, entendidos como

atividade administrativa de estimulação (...), ações do Poder Público voltadas à proteção, orientação, incentivo, estimulação; dirigidos a promover o desenvolvimento de determinada atividade de utilidade pública, mas que está sendo exercida pela iniciativa privada ${ }^{182}$.

Daí nota-se que os estímulos positivos são imprescindíveis para a indução do desenvolvimento do Brasil e que, para o desenvolvimento econômico, são necessárias medidas de orientação, incentivo e estimulação, todas elas no âmbito da prestação de serviços públicos.

Eles exemplificam as possíveis formas de estímulos positivos da Administração da seguinte maneira ${ }^{183}$ :

- Fomento: inserção de capital em atividade privada de natureza pública ou econômica;

- Subvenção: cobertura de despesas de custeio de entidades públicas ou privadas, bem como suplementação de recursos privados na área social;

- Remanejamento fiscal: fazer ou deixar de fazer incidir impostos em determinadas áreas de interesse estatal, ou aumentar ou diminuir alíquotas de acordo com o interesse estatal;

${ }^{181}$ QUEIROZ, João Eduardo Lopes; SANTOS, Márcia Walquiria Batista dos. Direito administrativo econômico. São Paulo: Atlas, 2011, p. 184.

${ }^{182}$ Idem, p. 175.

${ }^{183}$ Idem, p. 175-179. 
- Preempção aos produtos nacionais: concessão de preferência aos produtos nacionais, inclusive mediante proteção e benefícios especiais temporários para desenvolvimento de atividades consideradas estratégicas para a defesa nacional ou imprescindíveis ao desenvolvimento do país;

- Apoio técnico: treinamentos oferecidos pelos órgãos públicos de informação.

Todas essas formas de estímulos positivos, certamente, se aplicadas com finalidades ambientais, trarão benefícios de incalculável valia. Daí porque a Administração deve disponibilizá-las, na forma de serviços públicos, às pessoas físicas ou jurídicas.

Na temática ambiental, merece destaque especial o apoio técnico, principalmente com relação aos pequenos proprietários e empresários. A disseminação de técnicas ambientalmente corretas e economicamente mais eficientes pode trazer importantes ganhos ao meio ambiente, à sociedade e à economia.

O apoio técnico pode estar voltado a procedimentos de plantio; utilização racional da água; exploração correta de áreas com desnível a fim de evitar erosão; aproveitamento de energia solar, eólica ou hidráulica, dentre tantas outras possibilidades.

Por fim, ainda nesta temática, convém ressaltar um importante princípio apontado por João Eduardo Lopes Queiroz e Márcia Walquiria Batista dos Santos: o princípio da aproximação dos serviços às populações, que consiste "na estruturação da Administração de forma a tornar os serviços por ela prestados mais acessíveis à população" ${ }^{184}$.

Há regiões do Brasil em que a carência de serviços públicos acarreta sérios problemas ambientais, tal como contaminação do solo e da água superficial e subterrânea, principalmente em razão da falta de saneamento básico.

\footnotetext{
${ }^{184}$ Idem, p. 143.
} 
Convém apontar, todavia, que o favorecimento do poder público a determinadas comunidades ou proprietários pode incorrer em afronta aos princípios da isonomia e da igualdade dos usuários. Isso significa que os incentivos devem ser oferecidos a todos aqueles que cumprirem critérios objetivos mínimos a serem estabelecidos, de forma que não ocorra discriminação.

\subsubsection{Disponibilização de tecnologia}

Uma das formas de se reduzir os impactos e danos ambientais na atividade econômica é o emprego de técnicas mais eficientes, que demandem menos recursos naturais e geram menos desperdício. As técnicas de produção evoluem conforme evolui a tecnologia.

Por isso, a disponibilização de tecnologia ou a facilitação ao seu acesso pode representar um aumento da eficiência do setor produtivo, ao mesmo tempo que reduz os impactos e os danos ambientais.

A título de exemplo, a Empresa Brasileira de Pesquisa Agropecuária (Embrapa) tem viabilizado soluções de pesquisa, desenvolvimento e inovação para a sustentabilidade da agricultura brasileira. No período entre 1976 e 2011, a área plantada destinada a grãos e sementes oleaginosas aumentou 43,92\%, enquanto a produção aumentou por volta de $249,56 \%$ e os rendimentos aumentaram 2,4 vezes $^{185}$.

$\mathrm{Na}$ mesma linha, o Instituto Via Publica apresentou ao Ministério do Meio Ambiente, patrocinado pela Fundação ClimateWorks, um relatório denominado "Estudo de Alternativas de Tratamento de Resíduos Sólidos Urbanos"186. O estudo foi concluído em dezembro de 2012 e expõe o resultado de uma análise comparativa entre duas rotas tecnológicas de tratamento dos resíduos sólidos urbanos: mass burn e biodigestores anaeróbicos.

\footnotetext{
${ }^{185}$ Disponível em: <http://www.embrapa.br/a_embrapa/missao_e_atuacao>. Acesso em: 31 março 2014. ${ }^{186}$ Disponível em: $<$ http://www.fbes.org.br/index.php?option=com_docman\&task=doc_details\&Itemid=18\&gid=1766>. Acesso em: 31 março 2014.
} 
Lembre-se de que a ideia de incentivos a empresas voltadas à melhoria da qualidade do meio ambiente já foi incorporada pelo legislador brasileiro. Nessa linha, previu-se como instrumento da Política Nacional do Meio Ambiente a concessão de incentivos à produção e instalação de equipamentos voltados à melhoria da qualidade ambiental na Lei $\mathrm{n}^{\mathrm{o}} 6.938 / 1981$ (artigo $9^{\circ}$, inciso V) ${ }^{187}$.

\subsubsection{Pagamento por serviços ambientais}

O pagamento por serviços ambientais (PSA) encontra-se em destaque na atual conjuntura brasileira, seja pelo desenvolvimento da doutrina, seja por sua previsão expressa na legislação estadual de alguns Estados brasileiros ${ }^{188}$. É fruto do reconhecimento e dos estudos das consequências trazidas pela exploração dos recursos naturais, do seu valor econômico e da sua importância para a sociedade.

Ainda não há um padrão adotado em âmbito federal para a implementação de leis de PSA. Em alguns Estados, como o de São Paulo, a lei de PSA foi instituída no âmbito de uma política de mudanças climáticas. Em outros casos, como no Rio de Janeiro, insere-se no âmbito de uma política de recursos hídricos.

Embora ainda existam muitas lacunas no ordenamento jurídico quanto ao tema, é possível dizer que o Brasil já implementou o PSA como modalidade de incentivo a condutas benéficas ao meio ambiente.

Por serviços ambientais, entendam-se os serviços relativos ao suporte da natureza, tais como a polinização natural, a ciclagem de nutrientes do solo, o fluxo de genes, a manutenção do volume e qualidade dos recursos hídricos, o sequestro de carbono

\footnotetext{
${ }^{187}$ Cf. artigo $9^{\circ}$ da Lei $n^{\circ}$ 6.938/1981. “Art $9^{\circ}$ São instrumentos da Política Nacional do Meio Ambiente: (...) $\mathrm{V}$ - os incentivos à produção e instalação de equipamentos e a criação ou absorção de tecnologia, voltados para a melhoria da qualidade ambiental (...)" (BRASIL. Lei no 6.938 de 31 de agosto de 1981. Disponível em: < http://www.planalto.gov.br/ccivil_03/leis/16938.htm>. Acesso em: 31 março 2014).

188 Atualmente, os seguintes Estados brasileiros contam com legislação sobre PSA: Acre (Lei Estadual $n^{\circ}$ 2.308/2010), Amazonas (Leis Estaduais n ${ }^{\circ}$ s 3.135/2007 e 3.184/2007, Decreto Estadual no 26.958/2007), Espírito Santo (Lei Estadual no 8.995/2008), Minas Gerais (Leis Estaduais n ${ }^{\circ}$ s 14.309/2002 e 17.727/2008, Decretos Estaduais n ${ }^{\circ}$ s 43.710/2004, 45.113/2009 e 45.175/2009), Paraná (Lei Estadual no 17.134/2012 e Decreto Estadual $n^{\circ} 4.381 / 2012$ ), Rio de Janeiro (Lei Estadual $n^{\circ} 3.239 / 1999$ e Decreto Estadual $n^{\circ}$ 42.029/2011), Santa Catarina (Lei Estadual n ${ }^{\circ}$ 14.675/2009 e Decreto Estadual no 15.133/2010) e São Paulo (Lei Estadual $n^{\circ} 13.798 / 2009$ e Decreto Estadual no 55.947/2010).
} 
que permite a estabilização climática, entre outros. Têm impactos positivos além da área onde são gerados, representando benefícios que as pessoas obtêm dos ecossistemas.

Nas palavras da Professora Ana Maria de Oliveira Nusdeo, serviços ambientais passam a ser transacionados quando se torna possível a
identificação da sua prestação entre grupos definidos de provedores e de
beneficiários, pois, como já analisado, tratam-se de bens públicos que vêm
passando por processos de superação das características de não exclusividade e
não rivalidade que permitem sua fruição por grupos identificados. Ainda assim,
sua comercialização implica muitos custos, inclusive altos custos de
transação ${ }^{189}$.

A rigor, os serviços ambientais são prestados pela natureza.

Por sua vez, o PSA é a transação voluntária por meio da qual uma atividade desenvolvida por um provedor de serviços ambientais, que conserve ou recupere um serviço ambiental previamente definido, é remunerada por um pagador de serviços ambientais, mediante a comprovação do atendimento das disposições previamente contratadas $^{190}$.

O mecanismo surge da necessidade de soluções artificiais para a disponibilização de certos serviços, nos casos em que isso é viável, mediante investimentos vultosos. Os compradores de serviços ambientais, por sua vez, são resultado da inexistência de determinados serviços gratuitos, da intenção de fazer doações ou de marketing ecológico.

Ana Maria de Oliveira Nusdeo ensina que, atualmente, existem 4 tipos de PSA: (i) conservação da biodiversidade; (ii) proteção a bacias hidrográficas; (iii) sequestro e estocagem de carbono e (iv) beleza cênica ${ }^{191}$.

\footnotetext{
${ }^{189}$ NUSDEO, Ana Maria de Oliveira. Pagamento por serviços ambientais... cit., p. 53.

${ }^{190}$ Definição trazida pelo artigo $3^{\circ}$, inciso III, do Decreto Estadual no $55.947 / 2010$, do Estado de São Paulo. Disponível em: <http://www.al.sp.gov.br/norma/?id=159791>. Acesso em: 31 março 2014.

${ }^{191}$ NUSDEO, Ana Maria de Oliveira. Pagamento por serviços ambientais... cit., p. 23.
} 
Também esclarece que o sistema acaba ocorrendo em 2 situações: (i) em um mercado com maior grau de maturidade ou (ii) em políticas sociais, sobretudo quando envolve governos e organizações não governamentais como intermediários, com o objetivo de redução da pobreza ${ }^{192}$.

No Brasil, apenas a segunda modalidade tem se desenvolvido, seja em razão da ausência de um mercado forte de ativos ambientais, seja pela tradição do País em focar nas políticas que envolvem o aspecto social.

No âmbito do PSA, o Poder Público pode se posicionar de várias formas diferentes e não excludentes: (i) como comprador, ao requerer serviços ambientais e pagar por sua disponibilização; (ii) como provedor, ao desenvolver serviços ambientais e disponibilizá-lo de forma gratuita ou onerosa à sociedade; (iii) como intermediário, quando participa da implementação ou da comercialização do PSA, em papel de fomentador, fiscalizador ou facilitador e (iv) como regulador, quando cria regras e modelos para o desenvolvimento do PSA.

No atual modelo desenvolvido nos Estados brasileiros, o Poder Público tem assumido o papel de comprador, intermediário e regulador, pois é quem edita as normas, quem fiscaliza os projetos propostos e quem remunera o prestador de serviços ambientais.

Ainda não há uma participação significativa de voluntários ou investidores. Para que isso ocorra, é necessária a criação de um mercado em nível nacional com regras estabelecidas, ou mesmo a existência de segurança jurídica para negociações bilaterais entre particulares ou entre o particular e o governo, em que regras próprias e específicas sejam definidas.

Pela inexistência de um mercado nacional e de regras práticas quanto ao assunto, a precificação dos serviços ambientais varia muito em cada caso concreto. Apenas a título de exemplo, os valores podem levar em consideração a área abrangida, os custos de oportunidade do proponente, o número de pessoas atingidas, os esforços do proponente, a região em que o projeto é realizado etc.

${ }^{192}$ Idem, p. 69. 
Na opinião de Ana Maria de Oliveira Nusdeo, é o Poder Público quem deve ditar as regras. Destaca que a consecução das finalidades principais do pagamento - garantia da conservação ecológica e equidade - não são possíveis sem a coordenação do Poder Público ${ }^{193}$.

Ainda explica que, na prática, se há um sistema de criação de créditos, a exemplo do Mecanismo de Desenvolvimento Limpo, no âmbito da Convenção-Quadro das Nações Unidas sobre Mudança do Clima ${ }^{194}$, haverá um crescimento da iniciativa privada. Se, ao contrário, o mecanismo se basear em outras formas de financiamento, como fundos nacionais ou internacionais, é grande a chance de desenvolvimento de um sistema coordenado pelo Poder Público.

Importante notar que as negociações de PSA pressupõem a existência de alguma forma contratual, ainda que consistente em um termo de compromisso, no qual os provedores do serviço assumem obrigações determinadas e submetem-se à verificação quanto ao seu cumprimento. $\mathrm{O}$ comprador assume a obrigação de promover o pagamento nos montantes e periodicidade definidos.

A responsabilidade por danos causados à outra parte ou a terceiros pode ser definida nesses contratos. Da mesma forma, é possível que leis específicas estabeleçam regras de responsabilidade, o que permite a busca pela isonomia entre as partes e o equilíbrio contratual.

\subsubsection{Criação de lista ou de ranking das pessoas com boas práticas ambientais}

O mecanismo de criação de lista tem ampla aplicação no Brasil, mas está, atualmente, focado no registro de pessoas com condutas lesivas ou ilegais. O exemplo mais conhecido é o cadastro de consumidores inadimplentes criado por instituições e

\footnotetext{
${ }^{193}$ Idem, p. 23.

${ }^{194}$ Disponível em: <http://www.mma.gov.br/clima/convencao-das-nacoes-unidas>. Acesso em: 31 março 2014.
} 
empresas do setor comercial brasileiro denominado "Serviço de Proteção ao Crédito" (SPC).

Empresas como a Serasa Experian ${ }^{195}$ também oferecem banco de dados de consumidores inadimplentes, a fim de evitar prejuízos aos comerciantes.

É válido citar, também, o cadastro criado pelo Ministério do Trabalho e Emprego de empresas e pessoas autuadas por exploração do trabalho escravo. O cadastro é divulgado no sítio oficial do Ministério do Trabalho e Emprego ${ }^{196}$ e atualizado periodicamente.

A inclusão do nome do infrator no cadastro ocorre após decisão administrativa final relativa a auto de infração lavrado em decorrência de ação fiscal, em que tenha havido a identificação de trabalhadores submetidos a condições análogas à de escravo, nos termos da Portaria Interministerial no 2/2011 do Ministério do Trabalho e Emprego e do Ministério de Estado Chefe da Secretaria de Direitos Humanos ${ }^{197}$.

Há, por enquanto, um número pequeno de iniciativas voltadas à criação de listas ou ranking positivos. Um exemplo que pode ser citado é o Cadastro Positivo do SPC. Trata-se de um banco de dados com informações de consumidores que têm histórico favorável de pagamento ${ }^{198}$. A iniciativa tem fundamento na Lei $\mathrm{n}^{\mathrm{o}} 12.414 / 2011^{199}$, regulamentada pelo Decreto $\mathrm{n}^{\mathrm{o}} 7.829 / 2012^{200}$.

\footnotetext{
${ }^{195}$ Disponível em: <www.serasaexperian.com.br>. Acesso em: 31 março 2014.

196 Disponível em: <http://portal.mte.gov.br/trab_escravo/portaria-do-mte-cria-cadastro-de-empresas-epessoas-autuadas-por-exploracao-do-trabalho-escravo.htm>. Acesso em: 31 março 2014.

${ }^{197}$ BRASIL. Ministério do Trabalho e Emprego. Portaria Interministerial no 2, de 12 de maio de 2011. Disponível em:

<http://portal.mte.gov.br/data/files/8A7C816A2E7311D1012FFA7DD87E4E75/p_20110512_2.pdf>. Acesso em: 31 março 2014.

198 Disponível em: <https://www.spcbrasil.org.br/consumidor/cadastro-positivo>. Acesso em: 31 março 2014.

199 BRASIL. Lei $\mathrm{n}^{\mathrm{o}}$ 12.414, de 9 de julho de 2011. Disponível em: <http://www.planalto.gov.br/ccivil_03/_Ato2011-2014/2011/Lei/L12414.htm>. Acesso em: 31 março 2014.

200 BRASIL. Decreto $\mathrm{n}^{\mathrm{o}}$ 7.829, de 17 de outubro de 2012. Disponível em: $<$ http://www.planalto.gov.br/ccivil_03/_Ato2011-2014/2012/Decreto/D7829.htm>. Acesso em: 31 março 2014.
} 
Outro exemplo, utilizado no mercado financeiro, é o Índice de Sustentabilidade Empresarial (ISE). Trata-se de uma ferramenta para análise comparativa da performance das empresas listadas na Bolsa de Valores, Mercadorias e Futuros de São Paulo (BM\&FBOVESPA) sob o aspecto da sustentabilidade corporativa, baseada em eficiência econômica, equilíbrio ambiental, justiça social e governança corporativa ${ }^{201}$.

O ISE amplia o entendimento sobre empresas e grupos comprometidos com a sustentabilidade, diferenciando-os em termos de qualidade, nível de compromisso com o desenvolvimento sustentável, equidade, transparência e prestação de contas, natureza do produto, além do desempenho empresarial nas dimensões econômico-financeira, social, ambiental e de mudanças climáticas.

Na seara ambiental, à exclusão do ISE, não há listas ou ranking positivos. Para uma pesquisa sobre o histórico de infrações ambientais de uma pessoa física ou jurídica, é necessário consultar formalmente todos os órgãos ambientais municipais, estaduais e federais, além das promotorias do Ministério Público, os tribunais de cada um dos Estados (Justiça Estadual) e das seções judiciárias (Justiça Federal).

É importante que sejam criadas listas ou ranking das pessoas com boas práticas ambientais, seja para estimular os particulares, seja para facilitar sua comprovação de regularidade com a legislação ambiental. A lista também auxiliaria na análise de instituições financeiras quanto aos riscos de concessão de empréstimos.

\subsubsection{Criação de instrumentos de mercado}

Os instrumentos de mercado estabelecem direitos transacionáveis que podem estar relacionados a créditos referentes à redução de emissão de substância poluentes, à preservação ambiental, à reposição de recursos naturais, à redução de emissão de gases de efeito estufa etc.

\footnotetext{
201 Disponível em: <http://www.bmfbovespa.com.br/indices/ResumoIndice.aspx?Indice=ISE\&idioma=ptbr\#>. Acesso em: 31 março 2014.
} 
O mecanismo estimula o setor produtivo a reduzir seus impactos ambientais, para que eventuais créditos gerados dessa redução possam ser comercializados e refletirem renda adicional ao negócio. As pessoas tentarão reduzir ao máximo a sua poluição, de forma a ganhar cada vez mais proventos com a venda dos direitos.

Nas palavras de Stephanie Goldfine, os participantes do mercado são os atores racionais que estão na melhor posição para alterar seu próprio comportamento, e são motivados pela obtenção de lucro ${ }^{202}$. Aponta que os participantes do mercado têm uma base considerável de conhecimento, a habilidade para tomar decisões que afetam o mercado e o desejo de obter lucro, motivo pelo qual estão em situação privilegiada e ideal para, mediante uma análise de custo-benefício, determinar quais as melhores medidas a serem tomadas ${ }^{203}$.

Um exemplo implantado em nível internacional é o mercado de carbono, seja aquele desenvolvido pelas regras da Convenção-Quadro das Nações Unidas sobre Mudança do Clima $^{204}$ e seu Protocolo de Quioto $^{205}$, seja aquele realizado de maneira voluntária, em que certificadoras internacionais emitem certificados de redução com base em suas próprias regras.

No Brasil, um outro exemplo refere-se à Cota de Reserva Ambiental (CRA), criada pela Lei $\mathrm{n}^{\mathrm{o}} 12.651 / 2012^{206}$, definida como um título nominativo representativo de área de vegetação nativa existente ou em processo de recuperação ${ }^{207}$. Cada CRA

\footnotetext{
${ }^{202}$ GOLDFINE, Stephanie. Using economic incentives to promote environmentally sound business practices: A look at germany's experience with its regulation on the avoidance of packaging waste. HeinOnline, 7 Geo. Int'l Envtl. L. Rev. 309, 1994, p. 311. Disponível em: <www.heinonline.org>. Acesso em: 31 março 2014. Tradução livre do autor desta Dissertação. Do original: “(...) Market participants are rational actors who are best positioned to change their own market behavior, and who are primarily motivated by potential profits".

${ }^{203}$ Idem, p. 312. Quanto ao ponto, a autora destaca: “(...) market participants have a unique knowledge base, have the ability to take action that affects the market, and have the desire to maximize profits. Individual entities are thus in the best position to insure that the most efficient response to any change in the market will result when they have the ability to effect that change. Because market participants are profit maximizers, a cost-benefit analysis comparing all potential choices for action will determine the actual course pursued".

${ }^{204}$ Disponível em: <http://www.mma.gov.br/clima/convencao-das-nacoes-unidas $>$. Acesso em: 31 março 2014.

${ }^{205}$ Disponível em: <http://www.mma.gov.br/clima/protocolo-de-quioto>. Acesso em: 31 março 2014.

206 BRASIL. Lei $\mathrm{n}^{\mathrm{o}} 12.651$ de 25 de maio de 2012. Disponível em: <http://www.planalto.gov.br/ccivil_03/_ato2011-2014/2012/lei/112651.htm>. Acesso em: 31 março 2014.

${ }^{207}$ Cf. artigo 44 da Lei no 12.651/2012. "Art. 44. É instituída a Cota de Reserva Ambiental - CRA, título nominativo representativo de área com vegetação nativa, existente ou em processo de recuperação (...)"
} 
representa 1 hectare de área com vegetação. A CRA permite que sejam negociados títulos entre proprietários para fins de cumprimento da legislação ambiental quanto às áreas que devem ser preservadas no interior das propriedades.

Também no Brasil, estão sendo criados inúmeros instrumentos pela Bolsa de Valores ambientais denominada Bolsa Verde do Rio de Janeiro (BVRio). Atualmente, há propostas de instrumentos econômicos nos seguintes mercados: florestal, logística reversa e carbono, conforme segue ${ }^{208}$ :

- Contratos de Desenvolvimento e Venda de Cotas de Reserva Ambiental para Entrega Futura (CRAFs): títulos que estabelecem obrigações entre aqueles que têm excedente de Reserva Legal (vendedores) e aqueles que queiram comprar CRAs para se adequar aos requerimentos da legislação ambiental. Por meio do CRAF, o vendedor se compromete a criar as CRAs e entregá-las ao comprador mediante o pagamento, a ser realizado na entrega, de um preço previamente acordado entre as partes;

- Créditos de Reposição Florestal (CRF): títulos representativos de volume de matéria-prima resultante de plantio florestal para geração de estoque ou recuperação de cobertura florestal. Os CRFs serão emitidos para os proprietários rurais que realizarem plantio florestal de modo adequado e voluntário. Poderão ser vendidos aos devedores da obrigação de reposição florestal;

- Créditos de Destinação Adequada (CDAs): títulos representativos de destinação final ambientalmente adequada de resíduos sólidos. A instituição que realizar a destinação final ambientalmente adequada receberá um CDA, que poderá ser vendido ao produtor ou importador, para que estes possam cumprir suas obrigações de destinação final ambientalmente adequada junto à autoridade ambiental competente;

- Créditos de carbono: títulos representativos da redução de emissões de gases de efeito estufa. Podem ser emitidos no âmbito do Protocolo de Quioto ou do mercado voluntário.

(BRASIL. Lei $\mathrm{n}^{\mathrm{o}}$ 12.651, de 25 de maio de 2012. Disponível em: $<$ http://www.planalto.gov.br/ccivil_03/_ato2011-2014/2012/lei/112651.htm>. Acesso em 31: março 2014).

${ }^{208}$ Disponível em: <http://www.bvrio.org/site/index.php/mercados>. Acesso em: 31 março 2014. 
Na Alemanha, o mercado de permissões para a emissão de efluentes contribuiu significativamente para a redução das emissões abaixo dos níveis estabelecidos pelas normas federais. Como reporta Eckard Rehbinder, professor da University of Frankfurt, trata-se de um típico instrumento de mercado com efeitos positivos nas políticas ambientais $^{209}$.

O sistema de mercado de permissões também é encorajado pela doutrina norteamericana e trouxe resultados positivos para o país do ponto de vista ambiental ${ }^{210}$.

\footnotetext{
${ }^{209}$ REHBINDER, Eckard. Environmental regulation through fiscal and economic incentives in a federalist system. HeinOnline, 20 Ecology L.Q. 57, 1993. Disponível em: <www.heinonline.org>. Acesso em: 31 março 2014, p. 74. Quanto ao tema, Eckard Rehbinder relata: "The charges are merely artificially set prices for the use of the absorption capacity of environmental media. Thus, in reality, the charges are not market instruments. They are but a special type of interventionist strategy that makes an instrumental use of the market, forcing firms to internalize the state-determined costs of environmental degradation. By contrast, transferable permits are more purely Market instruments. They involve a simple subdivision of allowable total emissions, so their price is the result of market forces and need not be set artificially. In this respect, transferable permits have clear advantages".

${ }^{210}$ GOLDFINE, Stephanie. Op. cit., p. 314. Quanto ao ponto, Stephanie Goldfine destaca: "In the U.S., much of the literature advocating the use of economic incentives in the environmental area has concerned the use of marketable permits. In this type of program, the government establishes a tradable pollution right and allows industry to decide the appropriate allocation of that right. The government establishes an acceptable level of pollution. The level may include a component that reduces the acceptable level over time at a rate of change determined acceptable for the reduction of pollution on a regional, industry-wide basis. By setting an acceptable level of pollution, the government in essence allocates pollution rights to companies. Companies that do not utilize their full pollution quota are free to sell their remaining quota on the open market".
} 


\section{CAPÍTULO 5 - A EXPERIÊNCIA BRASILEIRA NA CONCESSÃO DE INCENTIVOS AMBIENTAIS}

Este Capítulo apresenta a experiência brasileira na concessão de incentivos. Serão citadas as normas em níveis federal, estadual e municipal que tratam do assunto, com destaque para a experiência do Estado de São Paulo com o PSA. Será também discutido o posicionamento da doutrina e da jurisprudência quanto ao tema.

\subsection{Normas vigentes que concedem incentivos ambientais}

As normas que concedem incentivos ambientais têm formado um importante sistema de estímulo às boas práticas ambientais nas esferas federal, estadual e municipal no Brasil. A seguir, serão citadas as principais normas atualmente em vigor.

Apesar de sua forte característica de comando e controle, cite-se a Lei da Política Nacional do Meio Ambiente (Lei $n^{\circ} 6.938 / 1981^{211}$ ), que previu como princípio a concessão de incentivos ao estudo e à pesquisa de tecnologias orientadas para o uso racional e a proteção dos recursos ambientais (artigo $2^{\circ}$, inciso $\mathrm{VI}^{212}$ ). A mesma lei ainda estabelece como instrumento de implementação da Política Nacional do Meio Ambiente a concessão de incentivos à produção e instalação de equipamentos e a criação ou absorção de tecnologia, voltados para a melhoria da qualidade ambiental (artigo $9^{\circ}$, inciso $\mathrm{V}^{213}$ ).

\footnotetext{
211 BRASIL. Lei $\mathrm{n}^{\mathrm{o}} 6.938$ de 31 de agosto de 1981. Disponível em: <http://www.planalto.gov.br/ccivil_03/leis/16938.htm>. Acesso em: 31 março 2014.

${ }^{212}$ Cf. artigo $2^{\circ}$ da Lei $n^{\circ}$ 6.938/1981. "Art $2^{\circ}$ A Política Nacional do Meio Ambiente tem por objetivo a preservação, melhoria e recuperação da qualidade ambiental propícia à vida, visando assegurar, no País, condições ao desenvolvimento sócio-econômico, aos interesses da segurança nacional e à proteção da dignidade da vida humana, atendidos os seguintes princípios: (...) VI - incentivos ao estudo e à pesquisa de tecnologias orientadas para o uso racional e a proteção dos recursos ambientais (...)" (BRASIL. Lei $\mathrm{n}^{\circ}$ 6.938 de 31 de agosto de 1981. Disponível em: <http://www.planalto.gov.br/ccivil_03/leis/16938.htm>. Acesso em: 31 março 2014).

${ }^{213}$ Cf. artigo $9^{\circ}$ da Lei $n^{\circ}$ 6.938/1981. “Art $9^{\circ}$ São instrumentos da Política Nacional do Meio Ambiente: (...) $\mathrm{V}$ - os incentivos à produção e instalação de equipamentos e a criação ou absorção de tecnologia, voltados para a melhoria da qualidade ambiental (...)" (BRASIL. Lei no 6.938 de 31 de agosto de 1981. Disponível em: <http://www.planalto.gov.br/ccivil_03/leis/16938.htm>. Acesso em: 31 março 2014).
} 
Citemos também a Lei $n^{0} 11.428 / 2006^{214}$, que tratou da utilização e proteção da vegetação nativa do bioma Mata Atlântica. A Lei da Mata Atlântica, como ficou nacionalmente conhecida, prevê que, sem prejuízo das obrigações assumidas pelos proprietários e posseiros, sejam concedidos incentivos econômicos para estimular a proteção e o uso sustentável do bioma (artigo $33^{215}$ ).

A mesma lei, no artigo 41, ainda prevê a concessão de incentivos creditícios para o proprietário ou posseiro que tenha vegetação primária ou secundária em estágios avançado e médio de regeneração do Bioma Mata Atlântica. Com isso, os pequenos produtores rurais e as populações tradicionais terão prioridade na concessão de crédito agrícola (inciso I do artigo $41^{216}$ ).

Também em nível federal, convém apontar a Lei $\mathrm{n}^{\mathrm{o}} 12.187 / 2009^{217}$, que instituiu a Política Nacional sobre Mudança do Clima. No artigo $5^{\circ}$, inciso VII ${ }^{218}$, é previsto como diretriz da Política a utilização de instrumentos financeiros e econômicos para promover ações de mitigação e adaptação à mudança do clima. Como instrumentos da Política Nacional, são previstas medidas fiscais e tributárias destinadas a estimular a redução de emissões e remoção de gases de efeito estufa, incluindo alíquotas diferenciadas, isenções, compensações e incentivos, a serem estabelecidos em lei específica (artigo $6^{\circ}, \mathrm{VI}^{219}$ ).

214 BRASIL. Lei $\mathrm{n}^{\mathrm{o}} 11.428$, de 22 de dezembro de 2006. Disponível em: $<$ http://www.planalto.gov.br/ccivil_03/_ato2004-2006/2006/lei/111428.htm>. Acesso em: 31 março 2014.

215 Cf. artigo 33 da Lei $n^{\circ} 11.428 / 2006$. "Art. 33. O poder público, sem prejuízo das obrigações dos proprietários e posseiros estabelecidas na legislação ambiental, estimulará, com incentivos econômicos, a proteção e o uso sustentável do Bioma Mata Atlântica" (BRASIL. Lei $\mathrm{n}^{\circ} 11.428$, de 22 de dezembro de 2006. Disponível em: <http://www.planalto.gov.br/ccivil_03/_ato2004-2006/2006/lei/111428.htm>. Acesso em: 31 março 2014).

${ }^{216}$ Cf. artigo 41 da Lei n ${ }^{\circ} 11.428 / 2006$. "Art. 41. O proprietário ou posseiro que tenha vegetação primária ou secundária em estágios avançado e médio de regeneração do Bioma Mata Atlântica receberá das instituições financeiras benefícios creditícios, entre os quais: I - prioridade na concessão de crédito agrícola, para os pequenos produtores rurais e populações tradicionais" (BRASIL. Lei n ${ }^{\circ} 11.428$, de 22 de dezembro de 2006. Disponível em: <http://www.planalto.gov.br/ccivil_03/_ato20042006/2006/lei/111428.htm>. Acesso em: 31 março 2014).

217 BRASIL. Lei $\mathrm{n}^{\mathrm{o}} 12.187$, de 29 de dezembro de 2009. Disponível em: $<$ http://www.planalto.gov.br/ccivil_03/_ato2007-2010/2009/lei/112187.htm>. Acesso em: 31 março 2014.

${ }^{218}$ Cf. artigo $5^{\circ}$ da Lei $n^{\circ} 12.187 / 2009$. "Art. $5^{\circ}$ São diretrizes da Política Nacional sobre Mudança do Clima: (...) VII - a utilização de instrumentos financeiros e econômicos para promover ações de mitigação e adaptação à mudança do clima, observado o disposto no art. $6^{\circ}$ (...)" (BRASIL. Lei n ${ }^{\circ} 12.187$, de 29 de dezembro de 2009. Disponível em: <http://www.planalto.gov.br/ccivil_03/_ato20072010/2009/lei/112187.htm>. Acesso em: 31 março 2014).

${ }^{219}$ Cf. artigo $6^{\circ}$ da Lei ${ }^{\circ} 12.187 / 2009$. "Art. $6^{\circ}$ São instrumentos da Política Nacional sobre Mudança do Clima: (...) VI - as medidas fiscais e tributárias destinadas a estimular a redução das emissões e remoção de gases de efeito estufa, incluindo alíquotas diferenciadas, isenções, compensações e incentivos, a serem estabelecidos em lei específica (...)" (BRASIL. Lei n 12.187, de 29 de dezembro de 2009. Disponível em: $<$ http://www.planalto.gov.br/ccivil_03/_ato2007-2010/2009/lei/112187.htm>. Acesso em: 31 março 2014). 
A Política Nacional de Resíduos Sólidos, instituída pela Lei $\mathrm{n}^{\circ}$ 12.305/2010 220 , traz inúmeros dispositivos em que incentivos são criados para possibilitar o gerenciamento dos resíduos sólidos em território brasileiro. A título de exemplo, o artigo $7^{0^{221}}$ da norma determina a concessão de (i) incentivo à indústria da reciclagem para fomentar o uso de matérias-primas e insumos derivados de materiais recicláveis e reciclados; (ii) incentivo ao desenvolvimento de sistemas de gestão ambiental e empresarial voltados para a melhoria dos processos produtivos e ao reaproveitamento dos resíduos sólidos, incluídos a recuperação e o aproveitamento energético e (iii) estímulo à rotulagem ambiental e ao consumo sustentável.

Adicionalmente, incentivos fiscais, financeiros e creditícios são expressamente definidos como instrumentos da Política Nacional de Resíduos Sólidos (artigo 8º inciso $\left.\mathrm{IX}^{222}\right)$.

Vale especial menção à Lei $n^{0} 12.512 / 2011^{223}$, que instituiu o Programa de Apoio à Conservação Ambiental.

220 BRASIL. Lei $\mathrm{n}^{\mathrm{o}}$ 12.305, de 2 de agosto de 2010. Disponível em: $<$ http://www.planalto.gov.br/ccivil_03/_ato2007-2010/2010/lei/112305.htm>. Acesso em: 31 março 2014.

${ }^{221}$ Cf. artigo $7^{\circ}$ da Lei n ${ }^{\circ} 12.305 / 2010$. “Art. $7^{\circ}$ São objetivos da Política Nacional de Resíduos Sólidos: I proteção da saúde pública e da qualidade ambiental; II - não geração, redução, reutilização, reciclagem e tratamento dos resíduos sólidos, bem como disposição final ambientalmente adequada dos rejeitos; III estímulo à adoção de padrões sustentáveis de produção e consumo de bens e serviços; IV - adoção, desenvolvimento e aprimoramento de tecnologias limpas como forma de minimizar impactos ambientais; V - redução do volume e da periculosidade dos resíduos perigosos; VI - incentivo à indústria da reciclagem, tendo em vista fomentar o uso de matérias-primas e insumos derivados de materiais recicláveis e reciclados; VII - gestão integrada de resíduos sólidos; VIII - articulação entre as diferentes esferas do poder público, e destas com o setor empresarial, com vistas à cooperação técnica e financeira para a gestão integrada de resíduos sólidos; IX - capacitação técnica continuada na área de resíduos sólidos; X regularidade, continuidade, funcionalidade e universalização da prestação dos serviços públicos de limpeza urbana e de manejo de resíduos sólidos, com adoção de mecanismos gerenciais e econômicos que assegurem a recuperação dos custos dos serviços prestados, como forma de garantir sua sustentabilidade operacional e financeira, observada a Lei n ${ }^{0} 11.445$, de 2007; XI - prioridade, nas aquisições e contratações governamentais, para: a) produtos reciclados e recicláveis; b) bens, serviços e obras que considerem critérios compatíveis com padrões de consumo social e ambientalmente sustentáveis; XII - integração dos catadores de materiais reutilizáveis e recicláveis nas ações que envolvam a responsabilidade compartilhada pelo ciclo de vida dos produtos; XIII - estímulo à implementação da avaliação do ciclo de vida do produto; XIV - incentivo ao desenvolvimento de sistemas de gestão ambiental e empresarial voltados para a melhoria dos processos produtivos e ao reaproveitamento dos resíduos sólidos, incluídos a recuperação e o aproveitamento energético; XV - estímulo à rotulagem ambiental e ao consumo sustentável" (BRASIL. Lei $\mathrm{n}^{\mathrm{o}}$ 12.305, de 2 de agosto de 2010. Disponível em: <http://www.planalto.gov.br/ccivil_03/_ato20072010/2010/lei/112305.htm>. Acesso em: 31 março 2014).

${ }^{222}$ Cf. artigo $8^{\circ}$ da Lei $n^{\circ} 12.305 / 2010$. “Art. $8^{\circ}$ São instrumentos da Política Nacional de Resíduos Sólidos, entre outros: (...) IX - os incentivos fiscais, financeiros e creditícios (...)” (BRASIL. Lei $\mathrm{n}^{\circ} 12.305$, de 2 de agosto de 2010. Disponível em: <http://www.planalto.gov.br/ccivil_03/_ato20072010/2010/lei/112305.htm>. Acesso em: 31 março 2014). 
A Lei apresenta como objetivos do Programa: (i) incentivar a conservação dos ecossistemas; (ii) promover a cidadania, a melhoria das condições de vida e a elevação da renda da população em extrema pobreza que exerça atividades de conservação dos recursos naturais no meio rural e (iii) incentivar a participação de seus beneficiários em ações de capacitação ambiental, social, educacional, técnica e profissional.

A norma autoriza que a União transfira recursos financeiros e disponibilize serviços de assistência técnica a famílias em situação de extrema pobreza que desenvolvam atividades de conservação de recursos naturais no meio rural (artigo $2^{\mathrm{o}^{224}}$ ).

Na mesma linha, a Lei $n^{\circ} 12.651 / 2012^{225}$ permite ao governo federal instituir

(...) programa de apoio e incentivo à conservação do meio ambiente, bem como para adoção de tecnologias e boas práticas que conciliem a produtividade agropecuária e florestal, com redução dos impactos ambientais, como forma de promoção do desenvolvimento ecologicamente sustentável (...) - artigo $41^{226}$.

223 BRASIL. Lei $\mathrm{n}^{\mathrm{o}}$ 12.512, de 14 de outubro de 2011. Disponível em: <http://www.planalto.gov.br/ccivil_03/_ato2011-2014/2011/Lei/L12512.htm>. Acesso: em 31 março 2014.

${ }^{224}$ Cf. artigo $2^{\circ}$ da Lei $n^{\circ} 12.51 \overline{2} / 2011$. "Art. $2^{\circ}$ Para cumprir os objetivos do Programa de Apoio à Conservação Ambiental, a União fica autorizada a transferir recursos financeiros e a disponibilizar serviços de assistência técnica a famílias em situação de extrema pobreza que desenvolvam atividades de conservação de recursos naturais no meio rural, conforme regulamento" (BRASIL. Lei no 12.512 , de 14 de outubro de 2011. Disponível em: <http://www.planalto.gov.br/ccivil_03/_ato20112014/2011/Lei/L12512.htm>. Acesso: em 31 março 2014).

225 BRASIL. Lei $\mathrm{n}^{\mathrm{o}}$ 12.651, de 25 de maio de 2012. Disponível em: $<$ http://www.planalto.gov.br/ccivil_03/_ato2011-2014/2012/lei/112651.htm>. Acesso em: 31 março 2014.

${ }^{226}$ Cf. artigo 41 da Lei no $12.651 / \overline{2} 012$. “Art. 41. É o Poder Executivo federal autorizado a instituir, sem prejuízo do cumprimento da legislação ambiental, programa de apoio e incentivo à conservação do meio ambiente, bem como para adoção de tecnologias e boas práticas que conciliem a produtividade agropecuária e florestal, com redução dos impactos ambientais, como forma de promoção do desenvolvimento ecologicamente sustentável, observados sempre os critérios de progressividade, abrangendo as seguintes categorias e linhas de ação" (BRASIL. Lei n ${ }^{\circ} 12.651$, de 25 de maio de 2012. Disponível em: <http:/www.planalto.gov.br/ccivil_03/_ato2011-2014/2012/lei/112651.htm>. Acesso em: 31 março 2014). 
Nesta linha, a Lei $\mathrm{n}^{\mathrm{o}} 12.854 / 2013^{227}$ :

(...) fomenta e incentiva ações que promovam a recuperação florestal e a implantação de sistemas agroflorestais em áreas rurais desapropriadas pelo Poder Público e em áreas degradadas em posse de agricultores familiares assentados, de quilombolas e de indígenas (artigo $1^{1^{228}}$ ).

A lei prevê a utilização de recursos de fundos nacionais e de outras fontes provenientes de acordos bilaterais ou multilaterais, de acordos decorrentes de ajustes, contratos de gestão e convênios celebrados com órgãos e entidades da Administração Pública federal, estadual ou municipal, de doações e, ainda, de verbas do orçamento da União ou privadas (artigo $\left.4^{\mathrm{o}}\right)^{229}$.

Daí pode-se inferir que o governo tem lançado mão de incentivos de caráter ambiental para garantir a proteção do meio ambiente, reforçando seu papel promocional. Especificamente no caso da Lei $\mathrm{n}^{\mathrm{o}} 12.512 / 2011^{230}$, foi ainda apresentado um mecanismo que trouxesse efeitos sociais positivos.

Em nível estadual, cite-se a Lei $n^{\circ} 13.798 / 2009^{231}$, do Estado de São Paulo, que cria a Política Estadual de Mudanças Climáticas. A norma prevê, em seu artigo $9^{\circ}, \S 2^{\mathrm{o}^{232}}$,

227 BRASIL. Lei $\mathrm{n}^{\mathrm{o}}$ 12.854, de 26 de agosto de 2013. Disponível em: $<$ http://www.planalto.gov.br/ccivil_03/_Ato2011-2014/2013/Lei/L12854.htm>. Acesso em: 31 março 2014.

${ }^{228}$ Cf. artigo $1^{\circ}$ da Lei $n^{\circ} 12.854 / 2013$. "Art. $1^{\circ}$ Esta Lei fomenta e incentiva ações que promovam a recuperação florestal e a implantação de sistemas agroflorestais em áreas rurais desapropriadas pelo Poder Público e em áreas degradadas em posse de agricultores familiares assentados, de quilombolas e de indígenas" (BRASIL. Lei $\mathrm{n}^{\mathrm{o}}$ 12.854, de 26 de agosto de 2013. Disponível em: $<$ http://www.planalto.gov.br/ccivil_03/_Ato2011-2014/2013/Lei/L12854.htm>. Acesso em: 31 março 2014).

${ }^{229}$ Cf. artigo $4^{\circ}$ da Lei $n^{\circ} 12.854 / 2013$. "Art. $4^{\circ}$ As ações de recuperação florestal e a implantação de sistemas agroflorestais poderão ser financiadas com recursos de fundos nacionais como o de Mudança do Clima, o da Amazônia, o do Meio Ambiente e o de Desenvolvimento Florestal, além de outras fontes provenientes de acordos bilaterais ou multilaterais, de acordos decorrentes de ajustes, contratos de gestão e convênios celebrados com órgãos e entidades da Administração Pública federal, estadual ou municipal, de doações e, ainda, de verbas do orçamento da União ou privadas" (BRASIL. Lei $n^{\circ} 12.854$, de 26 de agosto de 2013. Disponível em: <http://www.planalto.gov.br/ccivil_03/_Ato2011-2014/2013/Lei/L12854.htm>. Acesso em: 31 março 2014).

230 BRASIL. Lei $\mathrm{n}^{\mathrm{o}}$ 12.512, de 14 de outubro de 2011. Disponível em: <http://www.planalto.gov.br/ccivil_03/_ato2011-2014/2011/Lei/L12512.htm>. Acesso: em 31 março 2014. 231 SÃO PAULO. Lei Estadual $\bar{n}^{\circ}$ 13.798, de 9 de novembro de 2009. Disponível em: $<$ http://www.al.sp.gov.br/norma/?id=158351>. Acesso em: 31 março 2014.

${ }^{232}$ Cf. artigo $9^{\circ}$ da Lei Estadual n ${ }^{\circ} 13.798 / 2009$. “Art. $9^{\circ}$ O Estado criará e manterá o Registro Público de Emissões, com o objetivo de estabelecer critérios mensuráveis e o transparente acompanhamento do resultado de medidas de mitigação e absorção de gases de efeito estufa, bem como auxiliar os agentes privados e públicos na definição de estratégias para aumento de eficiência e produtividade. (...) $\S 2^{\circ} \mathrm{O}$ Poder 
a concessão de incentivos para pessoas que, voluntariamente, aderirem ao sistema de registro público de emissões de gases, sob a responsabilidade do Estado. São eles: (i) fomento para reduções de emissões de gases de efeito estufa; (ii) ampliação do prazo de renovação de licenças ambientais; (iii) priorização e menores taxas de juros em financiamentos públicos; (iv) certificação de conformidade e (v) incentivos fiscais.

Também no Estado de São Paulo, o Decreto Estadual no 59.260/2013 ${ }^{233}$ instituiu o Programa Estadual de Apoio Financeiro a Ações Ambientais, denominado Crédito Ambiental Paulista. O programa presta apoio financeiro a ações ambientais desenvolvidas por prefeituras, entidades, cidadãos e empresas e está voltado às seguintes iniciativas: (i) pagamento por serviços ambientais para conservação de remanescentes florestais e recuperação ecológica; (ii) ações voltadas ao incentivo à reciclagem, coleta e tratamento adequado de resíduos sólidos; (iii) educação ambiental e (iv) ações voltadas ao combate a incêndios em áreas florestais, agrícolas e pastoris.

O Crédito Ambiental Paulista é coordenado pela Secretaria de Meio Ambiente do Estado de São Paulo e conta com recursos do FECOP.

O Estado do Pará, por sua vez, editou a Lei Estadual no $7.638 / 2012^{234}$, pela qual estabeleceu incentivos ambientais aos municípios que abriguem em seu território unidades de conservação e outras áreas protegidas e que participem de sua implementação e gestão. De acordo com a lei, o repasse do Imposto sobre a Circulação de Mercadorias e Serviços (ICMS) deverá seguir critérios ecológicos (artigo $1^{\mathrm{o}^{235}}$ ), o que

Público definirá, entre outros, os seguintes incentivos para a adesão ao Registro Público: 1. fomento para reduções de emissões de gases de efeito estufa; 2. ampliação do prazo de renovação de licenças ambientais; 3. priorização e menores taxas de juros em financiamentos públicos; 4. certificação de conformidade; 5. incentivos fiscais (...)" (SÃO PAULO. Lei Estadual n 13.798, de 9 de novembro de 2009. Disponível em: $<$ http://www.al.sp.gov.br/norma/?id=158351>. Acesso em: 31 março 2014).

233 SÃO PAULO. Decreto Estadual $\mathrm{n}^{\mathrm{o}}$ 59.260, de 5 de junho de 2013. Disponível em: $<$ http://www.al.sp.gov.br/norma/?id=170434>. Acesso em: 31 março 2014.

234 PARÁ. Lei Estadual $\mathrm{n}^{\mathrm{o}} 7.638$, de 12 de julho de 2012. Disponível em: $<$ http://www.alepa.pa.gov.br/alepa/arquivos/bleis/bancodeleis12-02A1A14.pdf $>$. Acesso em: 31 março 2014.

${ }^{235}$ Cf. artigo $1^{\circ}$ da Lei Estadual n ${ }^{\circ} 7.638 / 2012$. “Art. $1^{\circ}$ As parcelas da receita de que trata o $\S 2^{\circ}$ do art. 225 da Constituição do Estado serão creditadas segundo o critério ecológico, sem prejuízo daqueles instituídos em outras leis" (PARÁ. Lei Estadual $n^{\circ}$ 7.638, de 12 de julho de 2012. Disponível em: $<$ http://www.alepa.pa.gov.br/alepa/arquivos/bleis/bancodeleis12-02A1A14.pdf $>$. Acesso em: 31 março 2014). O parágrafo $2^{\circ}$ do artigo 225 da Constituição do Estado do Pará tem o seguinte teor: "§ $2^{\circ}$ É assegurado aos Municípios que tenham parte de seus territórios integrando unidades de conservação ambiental, tratamento especial, quanto ao crédito das parcelas da receita referenciada no artigo 158 , IV e 
significa que haverá tratamento especial aos municípios que criarem e gerenciarem unidades de conservação e demais áreas protegidas ${ }^{236}$.

A lei foi regulamentada pelo Decreto Estadual $n^{\circ} 775 / 2013^{237}$ e pode representar um incremento de R\$ 35 milhões em 2014 nos municípios que se enquadrarem nos requisitos ambientais estabelecidos ${ }^{238}$.

No Estado de Minas Gerais, a Lei Estadual n n $^{\text {20.922/2013 }}{ }^{239}$ criou incentivos fiscais e incentivos especiais para toda pessoa física ou jurídica que (i) preservar e conservar vegetação nativa; (ii) implantar sistemas agroflorestais em áreas degradadas; (iii) recuperar áreas degradadas com espécies nativas; (iv) sofrer limitações ou restrições no uso de recursos naturais de sua propriedade, mediante ato do órgão competente federal, estadual ou municipal, para fins de proteção dos ecossistemas e de conservação do solo; (v) proteger e recuperar corpos d'água; (vi) praticar técnicas de agricultura de baixo carbono; (vii) criar e implantar Reserva Particular do Patrimônio Natural; (viii) contribuir na implantação e manutenção de Unidades de Conservação estaduais por meio de investimentos ou de custeio ou na administração dessas unidades por meio de cogestão ou (ix) praticar agricultura agroecológica ou orgânica (artigo $103^{240}$ ).

parágrafo único, II, da Constituição Federal, sem prejuízo de outras receitas, na forma da lei" (PARÁ. Constituição Estadual (1989). Disponível em:

$<$ http://www.sefa.pa.gov.br/LEGISLA/leg/Diversa/ConstEmendas/ConstEstadual/Constituicao\%20Para.ht $\mathrm{m}>$. Acesso em: 31 março 2014).

${ }^{236}$ De acordo com o artigo 158, IV, da Constituição Federal, 25\% do ICMS arrecadado pelo Estado pertence aos municípios. In verbis: “Art. 158. Pertencem aos Municípios: (...) IV - vinte e cinco por cento do produto da arrecadação do imposto do Estado sobre operações relativas à circulação de mercadorias e sobre prestações de serviços de transporte interestadual e intermunicipal e de comunicação" (BRASIL. $\begin{array}{lllll}\text { Constituição } & \text { Federal } & \text { (1988). } & \text { Disponível }\end{array}$ $<$ http://www.planalto.gov.br/ccivil_03/constituicao/constituicao.htm>. Acesso em: 31 março 2014).

237 PARÁ. Decreto Estadual $\mathrm{n}^{\circ} 775$, de 26 de julho de 2013. Disponível em: $<$ http://www.alepa.pa.gov.br/alepa/arquivos/bleis/bancodeleis12-0235b8b.pdf $>$. Acesso em: 31 março 2014.

${ }^{238}$ Disponível em: <http://www.valor.com.br/brasil/3176370/para-cria-incentivo-fiscal-para-reduzir-areasde-desmatamento>. Acesso em: 31 março 2014.

239 MINAS GERAIS. Lei Estadual $\mathrm{n}^{\circ}$ 20.922, de 16 de outubro de 2013. Disponível em: $<\mathrm{http}: / /$ www.almg.gov.br/consulte/legislacao/completa/completa-nova-

min.html?tipo=LEI\&num=20922\&comp=\&ano=2013\&texto $=$ original $>$. Acesso em: 31 março 2014 .

${ }^{240}$ Cf. artigo 103 da Lei Estadual $n^{\circ} 20.922 / 2013$. "Art . 103. O poder público, por meio dos órgãos competentes, criará normas de apoio e incentivos fiscais e concederá incentivos especiais para a pessoa física ou jurídica que: I - preservar e conservar vegetação nativa; II - implantar sistemas agroflorestais em áreas degradadas; III - recuperar áreas degradadas com espécies nativas; IV - sofrer limitações ou restrições no uso de recursos naturais de sua propriedade, mediante ato do órgão competente federal, estadual ou municipal, para fins de proteção dos ecossistemas e de conservação do solo; V - proteger e recuperar corpos d'água; VI - praticar técnicas de agricultura de baixo carbono, entre elas a integração lavoura-pecuária-floresta - ILPF; VII - criar e implantar Reservas Particulares do Patrimônio Natural; VIII 
Os incentivos criados envolvem: (i) a prioridade de atendimento nos programas de infraestrutura rural, notadamente nos programas de proteção e recuperação do solo, energização, irrigação, armazenagem, telefonia e habitação; (ii) a preferência na prestação de serviços oficiais de assistência técnica e de fomento, notadamente ao pequeno produtor rural e ao agricultor familiar; (iii) o fornecimento gratuito de mudas de espécies nativas ou ecologicamente adaptadas, produzidas com a finalidade de recompor a cobertura vegetal nativa; (iv) o apoio técnico-educativo no desenvolvimento de projetos de preservação, conservação e recuperação ambiental; (v) o apoio técnico-educativo, no caso de pequeno produtor rural e agricultor familiar, em projetos de reflorestamento, com a finalidade de suprir a demanda de produtos e subprodutos florestais e (vi) a concessão de incentivo financeiro, no caso de proprietário e possuidor rural, para recuperação, preservação e conservação de áreas necessárias à proteção da biodiversidade e ecossistemas especialmente sensíveis, nos termos da legislação vigente.

Em nível municipal, algumas prefeituras estabeleceram isenções ou reduções na cobrança do Imposto Predial e Territorial Urbano (IPTU) para os proprietários de imóveis que trouxessem ganhos ambientais à cidade. A iniciativa, popularmente denominada "IPTU Verde" ou "IPTU Ecológico", conta, pelo menos, com os seguintes municípios: Araraquara/SP (Lei Municipal $n^{\circ} 7.152 / 2009^{241}$ ); Cabo Frio/RJ (Lei Municipal $n^{\circ}$ 2.443/2012 242 ); Curitiba/PR (Lei Municipal no 9.806/2000²43); Guaíra/SP (Lei Municipal $n^{\text {o }} 2.491 / 2011^{244}$ ); São Vicente/SP (Lei Complementar Municipal no 634/2010 ${ }^{245}$ ); São

\footnotetext{
- contribuir na implantação e manutenção de Unidades de Conservação estaduais por meio de investimentos ou de custeio ou na administração dessas unidades por meio de cogestão; IX - praticar agricultura agroecológica ou orgânica. (...)" (MINAS GERAIS. Lei Estadual n 20.922, de 16 de outubro de 2013. Disponível em: <http://www.almg.gov.br/consulte/legislacao/completa/completa-novamin.html?tipo $=$ LEI\&num $=20922 \&$ comp $=\& a n o=2013 \&$ texto $=$ original $>$. Acesso em: 31 março 2014).

${ }^{241}$ ARARAQUARA. Lei Municipal $\mathrm{n}^{\circ} 7.152$, de 8 de dezembro de 2009. Disponível em: $<$ https://www.leismunicipais.com.br/a/sp/a/araraquara/lei-ordinaria/2009/715/7152/lei-ordinaria-n-71522009-concede-isencao-de-imposto-predial-e-territorial-urbano-para-propriedades-que-conservarem-areaarborizada-iptu-verde-2009-12-08.html >. Acesso em: 31 março 2014.

${ }^{242}$ CABO FRIO. Lei Municipal $\mathrm{n}^{\circ}$ 2.443, de 19 de junho de 2012. Disponível em: $<$ http://www.cmcabofrio.rj.gov.br>. Acesso em: 31 março 2014.

${ }^{243}$ CURITIBA. Lei Municipal $\mathrm{n}^{\circ}$ 9.806, de 29 de março de 2010 de 2000. Disponível em: $<$ https://www.leismunicipais.com.br/a/pr/c/curitiba/lei-ordinaria/2000/980/9806/lei-ordinaria-n-9806-2000institui-o-codigo-florestal-do-municipio-de-curitiba-revoga-as-leis-n-8353-93-e-8436-94-e-da-outrasprovidencias.html>. Acesso em: 31 março 2014.

${ }^{244}$ GUAÍRA. Lei Municipal $\mathrm{n}^{\mathrm{o}} 2.491$, de 2 de março de 2011. Disponível em: <http://www.camaraguaira.sp.gov.br/camver/LEIMUN/2011/02491.pdf >. Acesso em: 31 março 2014.

${ }^{245}$ SÃO VICENTE. Lei Complementar Municipal no 634, de 5 de novembro de 2010. Disponível em: $<\mathrm{http}: / /$ www.saovicente.sp.gov.br/ambiental/pdf_12/04/634.pdf>. Acesso em: 31 março 2014.
} 
Bernardo do Campo/SP (Lei Municipal no 6.091/2010 246); Sorocaba/SP (Lei Municipal $n^{\circ}$ 9.571/2011 ${ }^{247}$ ); Guarulhos/SP (Lei Municipal $n^{\circ} 6.793 / 2010^{248}$ ) e Vila Velha/ES (Lei Municipal $n^{\circ} 4.864 / 2009^{249}$ ).

Pelo exposto, pode-se verificar que são cada vez mais presentes, no ordenamento jurídico, normas de caráter estimulador às boas práticas ambientais. É importante que o legislador siga neste rumo, para que as normas de proteção ao meio ambiente sejam cada vez mais eficazes.

\subsection{Incentivos na Lei de Crimes Ambientais}

Este item tratará, apenas a título de sugestão, da possibilidade de concessão de incentivos ambientais no âmbito da Lei $\mathrm{n}^{\mathrm{o}} 9.605 / 1998^{250}$, a Lei de Crimes Ambientais, em razão dos comentários que foram apresentados à norma no Capítulo 3.

Considerando as críticas que poderão ser feitas pela comunidade jurídica a essa ideia, salienta-se que o intuito de prever incentivos na Lei de Crimes Ambientais é, justamente, fortalecê-la.

\footnotetext{
${ }^{246}$ SÃO BERNARDO DO CAMPO. Lei Municipal no 6.091, de 9 de dezembro de 2010. Disponível em: $<$ https://www.leismunicipais.com.br/a2/sp/s/sao-bernardo-do-campo/lei-ordinaria/2010/609/6091/leiordinaria-n-6091-2010-disciplina-a-concessao-de-beneficio-fiscal-aos-imoveis-com-area-de-coberturavegetal-ou-destinados-a-producao-hortifrutigranjeira-e-da-outras-providencias.html? wordkeytxt=6091>. Acesso em: 31 março 2014.

247 SOROCABA. Lei Municipal $\mathrm{n}^{\circ}$ 9.571, de 16 de maio de 2011. Disponível em: $<$ http://www.camarasorocaba.sp.gov.br/sitecamara/proposituras/verpropositura $>$. Acesso em: 31 março 2014.

248 GUARULHOS. Lei Municipal $\mathrm{n}^{\circ}$ 6.793, de 28 de dezembro de 2010. Disponível em: $<$ http://leis.guarulhos.sp.gov.br/06_prefeitura/leis/leis_download/06793lei.pdf $>$. Acesso em: 31 março 2014.

249 VILA VELHA. Lei Municipal $\mathrm{n}^{\circ}$ 4.864, de 29 de dezembro de 2009. Disponível em: $<$ http://www.legislacaoonline.com.br/vilavelha/images/leis/html/L48642009.html>. Acesso em: 31 março 2014.

250 BRASIL. Lei $\mathrm{n}^{\mathrm{o}} 9.605$, de 12 de fevereiro de 1998. Disponível em: $<$ http://www.planalto.gov.br/ccivil_03/leis/19605.htm>. Acesso em: 31 março 2014.
} 
Lembrando as palavras de Terence Dorneles Trennepohl,

a punição, através da aplicação da sanção negativa, representando castigo e represália, mostra-se, no mundo contemporâneo, em flagrante decadência (...). As tendências mais modernas de descriminalização buscam a aplicação do Direito Penal Mínimo ${ }^{251}$.

Ou seja, o Direito Penal, incluindo o Direito Penal Ambiental, não pode ser utilizado como único instrumento para a proteção do meio ambiente, principalmente nos casos de difícil reparação dos danos, tal como ocorre nas questões ambientais. A sociedade e o Direito pedem pela descriminalização e clamam por normas de estímulo, ao notarem o declínio do sistema punitivo.

Todavia, é preciso, também, reconhecer o valor das normas punitivas no ordenamento jurídico. Por isso, opina-se pela manutenção do texto da Lei $n^{\circ}$ 9.605/1998, qual seja, descrição de sanções penais e administrativas, mas com a previsão de incentivos para determinados casos em que, em vez de uma infração, houver uma conduta pró-ambiente.

Acredita-se que uma mudança nesse nuance na Lei de Crimes Ambientais não prejudicará sua força ou aplicabilidade. Ao contrário, poderá torná-la aplicável em um número maior de casos, contribuindo com a conscientização da sociedade, a prevenção de danos ambientais, o fortalecimento do papel estimulador do Estado e a valorização das condutas benéficas ao meio ambiente.

Como destaca a doutrina, o tradicional criminoso ambiental não costuma oferecer grande periculosidade, razão pela qual não precisa ser recolhido ao cárcere ${ }^{252}$. $\mathrm{O}$ criminoso ou infrator ambiental tem um perfil que o diferencia dos que praticam outros ilícitos penais. Em geral, os crimes são socialmente aceitos, sem envolverem violência contra pessoa e estão ligados, normalmente, a aspectos econômicos. Penaliza-se, na maior parte das vezes, o fazendeiro, o mateiro, o dono de pequena propriedade rural ou o prestador temporário de serviços.

\footnotetext{
${ }^{251}$ TRENNEPOHL, Terence Dorneles. Op. cit., p. 41.

${ }^{252}$ FREITAS, Gilberto Passos de. Direito penal ambiental... cit., p. 409.
} 
Tal afirmativa merece uma exceção para os casos de atividades de grandes corporações ou atividades em que há uso de substâncias nocivas, quando há notável risco ao meio ambiente. Todavia, tal ocorrência não parece ser a regra.

Não por outra razão, à medida em que tais "criminosos" deixarem de vislumbrar vantagens no descumprimento da lei e visualizarem os incentivos existentes, deverá haver redução das atividades danosas ao meio ambiente.

No jargão popular, se a "floresta em pé" valer mais do que a madeira ilegalmente cortada, não haverá crime por corte de árvores. Da mesma forma, se houver um patrocínio àqueles que deixarem de queimar a cana ou outro tipo de vegetação, não haverá mais degradação da qualidade do ar por queimadas.

$\mathrm{Na}$ oportunidade, esclarece-se que não se pretende presentear os criminosos. Muito pelo contrário, tenta-se encontrar uma alternativa para que o verdadeiro escopo da legislação ambiental seja alcançado. O beneficiado, ressalte-se, será aquele que praticar conduta favorável ao equilíbrio do meio ambiente.

Com isso, será possível aliviar o trabalho exaustivo e complexo dos órgãos fiscalizadores e aplicadores das punições legais, os quais, nem sempre, conseguem encontrar a solução mais benéfica ao homem e seu ambiente - e quem paga por isso é a sociedade.

Também não se pretende, esclarece-se, revogar as disposições da Lei de Crimes Ambientais, já que as normas punitivas não estão em desarmonia com as normas incentivadoras.

Exemplo disso é a Lei da Mata Atlântica (Lei no $11.428 / 2006^{253}$ ), já citada no presente trabalho, que aplica sanções às condutas lesivas ao meio ambiente, sem dispensar a concessão de benefícios econômicos e creditícios aos praticantes de condutas condizentes com o equilíbrio ecológico.

253 BRASIL. Lei $\mathrm{n}^{\mathrm{o}} 11.428$, de 22 de dezembro de 2006. Disponível em: <http://www.planalto.gov.br/ccivil_03/_ato2004-2006/2006/lei/111428.htm>. Acesso em: 31 março 2014. 
Por tantos motivos, é bem vinda uma revisão dos termos da Lei de Crimes Ambientais, seja para o seu aperfeiçoamento técnico (definição pormenorizada dos tipos penais, penas proporcionais aos danos causados etc.), seja para sua maior eficácia. Deve ser estudada a possibilidade de concessão de benefícios àqueles que deixarem de praticar condutas danosas ao meio ambiente, ou que, proativamente, desenvolverem práticas que causem impactos positivos.

A título de exemplo, é possível a concessão de incentivo econômico àqueles que deixarem de desmatar sua propriedade. Sabe-se que, em algumas regiões do Brasil, a principal atividade econômica é, justamente, o desmate para a venda de madeira ou de carvão.

As consequências negativas dessa prática são inúmeras, seja para o homem, seja para o meio ambiente. A posterior recuperação ambiental dessas áreas custa milhares, senão milhões de reais. Além disso, muitas vezes são gastas quantias significativas para tratar as doenças advindas da migração de insetos e animais peçonhentos da mata para a sociedade. Numerosos também são os investimentos no aparelhamento dos fiscais e dos órgãos que deverão julgar e punir os malfeitores.

Por certo, a soma de todos esses gastos poderia ser distribuída entre aqueles que, simplesmente, deixassem de desmatar. Com isso, não haveria perdas ambientais, centenas ou milhares de processos deixariam de existir e a economia local sofreria um input positivo, dentre outras consequências. Na Lei de Crimes Ambientais ${ }^{254}$, os artigos 38 a $40^{255}$, por exemplo, poderiam contar com a concessão do referido incentivo.

254 BRASIL. Lei $\mathrm{n}^{\mathrm{o}}$ 9.605, de 12 de fevereiro de 1998. Disponível em: <http://www.planalto.gov.br/ccivil_03/leis/19605.htm>. Acesso em: 31 março 2014.

${ }^{255}$ Cf. artigos 38 a 40 da Lei $\mathrm{n}^{\mathbf{0}}$ 9.605/1998. "Art. 38. Destruir ou danificar floresta considerada de preservação permanente, mesmo que em formação, ou utilizá-la com infringência das normas de proteção: Pena - detenção, de um a três anos, ou multa, ou ambas as penas cumulativamente. Parágrafo único. Se o crime for culposo, a pena será reduzida à metade." "Art. 38-A. Destruir ou danificar vegetação primária ou secundária, em estágio avançado ou médio de regeneração, do Bioma Mata Atlântica, ou utilizá-la com infringência das normas de proteção: Pena - detenção, de 1 (um) a 3 (três) anos, ou multa, ou ambas as penas cumulativamente. Parágrafo único. Se o crime for culposo, a pena será reduzida à metade. Art. 39. Cortar árvores em floresta considerada de preservação permanente, sem permissão da autoridade competente: Pena - detenção, de um a três anos, ou multa, ou ambas as penas cumulativamente. Art. 40. Causar dano direto ou indireto às Unidades de Conservação e às áreas de que trata o art. 27 do Decreto $\mathrm{n}^{\circ}$ 99.274, de 6 de junho de 1990, independentemente de sua localização: Pena - reclusão, de um a cinco anos. $\S 1^{\circ}$ Entende-se por Unidades de Conservação de Proteção Integral as Estações Ecológicas, as Reservas Biológicas, os Parques Nacionais, os Monumentos Naturais e os Refúgios de Vida Silvestre. $\S 2^{\circ}$ A ocorrência de dano afetando espécies ameaçadas de extinção no interior das Unidades de Conservação de 
O Governo Federal tem tomado medidas de caráter incentivador para a redução do desmatamento na Amazônia. Uma medida já adotada foi a edição do Decreto $\mathrm{n}^{\mathrm{o}}$ 6.527/2008 ${ }^{256}$, que cria o Fundo Amazônia. O Fundo, gerido pelo Banco Nacional de Desenvolvimento Econômico e Social (BNDES), receberá doações de entidades de todo o mundo e está voltado para ações de "prevenção, monitoramento e combate ao desmatamento e de promoção da conservação e do uso sustentável no bioma amazônico" (artigo $1^{\mathrm{o} 257}$ ).

Até o momento, o Fundo já recebeu doações que ultrapassam 128 milhões de dólares, sendo aproximadamente 112 milhões do governo da Noruega, 4 milhões da Petróleo Brasileiro S.A. - PETROBRAS e 12 milhões da Alemanha ${ }^{258}$.

Por tantos motivos, a previsão de incentivos na Lei de Crimes Ambientais significaria um avanço na legislação ambiental e um reconhecimento dos esforços do governo e da comunidade internacional em matéria de meio ambiente. Mais especificamente, nos casos dos crimes contra a flora que estejam relacionados ao desmatamento, muitas são as possibilidades de concessão de sanções premiais à pessoa que proteger o ambiente.

\footnotetext{
Proteção Integral será considerada circunstância agravante para a fixação da pena. $\S 3^{\circ} \mathrm{Se}$ o crime for culposo, a pena será reduzida à metade" (BRASIL. Lei n 9.605, de 12 de fevereiro de 1998. Disponível em: <http://www.planalto.gov.br/ccivil_03/leis/19605.htm>. Acesso em: 31 março 2014).

256 BRASIL. Decreto $\mathrm{n}^{\circ} 6.527$, de $1^{\circ}$ de agosto de 2008. Disponível em: <http://www.planalto.gov.br/ccivil_03/_Ato2007-2010/2008/Decreto/D6527.htm>. Acesso em: 31 março 2014.

${ }^{257}$ Cf. artigo $1^{\circ}$ do Decreto $n^{\circ}$ 6.527/2008. "Art. $1^{\circ}$ Fica o Banco Nacional de Desenvolvimento Econômico e Social - BNDES autorizado a destinar o valor das doações recebidas em espécie, apropriadas em conta específica denominada Fundo Amazônia, para a realização de aplicações não reembolsáveis em ações de prevenção, monitoramento e combate ao desmatamento e de promoção da conservação e do uso sustentável no bioma amazônico, contemplando as seguintes áreas: I - gestão de florestas públicas e áreas protegidas; II - controle, monitoramento e fiscalização ambiental; III - manejo florestal sustentável; IV - atividades econômicas desenvolvidas a partir do uso sustentável da floresta; V - Zoneamento Ecológico e Econômico, ordenamento territorial e regularização fundiária; VI - conservação e uso sustentável da biodiversidade; VII - recuperação de áreas desmatadas. (BRASIL. Decreto $\mathrm{n}^{\circ}$ 6.527, de $1^{\circ}$ de agosto de 2008. Disponível em: $<$ http://www.planalto.gov.br/ccivil_03/_Ato2007-2010/2008/Decreto/D6527.htm>. Acesso em: 31 março 2014).

${ }^{258}$ Disponível em: <http://www.fundoamazonia.gov.br/FundoAmazonia/fam/site_pt/Esquerdo/Doacoes/>. Acesso em: 31 março 2014.
} 


\subsection{A experiência do Estado de São Paulo com o PSA ${ }^{259}$}

Conforme reportado no Capítulo 4, é possível dizer que o Brasil já implementou o PSA como modalidade de incentivo a condutas benéficas ao meio ambiente, embora ainda existam algumas lacunas jurídicas.

No Estado de São Paulo, o PSA foi criado por meio da Lei Estadual $\mathrm{n}^{\circ}$ $13.798 / 2009^{260}$ que, em seu artigo $23^{261}$, criou o Programa de Remanescentes Florestais, no qual se permite o pagamento por serviços florestais ambientais aos proprietários rurais conservacionistas, bem como incentivos econômicos a políticas voluntárias de redução de desmatamento e proteção ambiental.

Convém notar que o instrumento foi inserido no âmbito de uma lei que instituiu a Política Estadual de Mudanças Climáticas, tendo forte viés de controle das emissões de gases de efeito estufa.

O Decreto Estadual $n^{0} 55.947 / 2010^{262}$ definiu condições e requisitos gerais para os projetos de PSA, restringindo sua aplicabilidade a serviços florestais. A instituição responsável pela coordenação do PSA no Estado é a Secretaria do Meio Ambiente do Estado de São Paulo.

A legislação menciona como principal objetivo desse sistema de PSA o fomento da delimitação, demarcação e recuperação de matas ciliares e outros tipos de fragmentos florestais. Também estão previstos como objetivos específicos a contribuição para a

\footnotetext{
259 As informações reportadas neste item refletem o resultado do trabalho desenvolvido pelo autor desta dissertação como consultor do instituto "O Direito por um Planeta Verde", no Estado de São Paulo, no Projeto "Sistemas estaduais de PSA: diagnóstico, lições aprendidas e desafios para a futura legislação", envolvendo reuniões com os órgãos públicos estaduais, órgãos municipais, instituições privadas, visitas a comunidades e análise de doutrina sobre PSA, no primeiro semestre de 2013.

260 SÃO PAULO. Lei Estadual $\mathrm{n}^{\mathrm{o}}$ 13.798, de 9 de novembro de 2009. Disponível em: $<$ http://www.al.sp.gov.br/norma/?id=158351>. Acesso em: 31 março 2014.

${ }^{261}$ Cf. artigo 23 da Lei Estadual no 13.798/2009 . "Art. 23. O Poder Executivo instituirá, mediante decreto, o Programa de Remanescentes Florestais, sob coordenação da Secretaria do Meio Ambiente, com o objetivo de fomentar a delimitação, demarcação e recuperação de matas ciliares e outros tipos de fragmentos florestais, podendo prever, para a consecução de suas finalidades, o pagamento por serviços florestais ambientais aos proprietários rurais conservacionistas, bem como incentivos econômicos a políticas voluntárias de redução de desmatamento e proteção ambiental" (SÃO PAULO. Lei Estadual n ${ }^{\circ}$ 13.798, de 9 de novembro de 2009. Disponível em: <http://www.al.sp.gov.br/norma/?id=158351 >. Acesso em: 31 março 2014).

262 SÃO PAULO. Decreto Estadual $n^{\circ}$ 55.947, de 24 de junho de 2010. Disponível em: $<$ http://www.al.sp.gov.br/norma/?id=159791>. Acesso em: 31 março 2014.
} 
mitigação das mudanças climáticas, a conservação da biodiversidade, ampliação da cobertura natural, restauração de paisagens fragmentadas, redução de processos de erosão e assoreamento, redução da pobreza no meio rural, dentre tantos outros.

Como serviços ambientais, foram previstas as seguintes atividades: conservação de remanescentes florestais; recuperação de matas ciliares e implantação de vegetação nativa para a proteção de nascentes; plantio de mudas de espécies nativas ou execução de práticas que favoreçam a regeneração natural para a formação de corredores de biodiversidade; reflorestamentos com espécies nativas ou com espécies nativas consorciadas com espécies exóticas para exploração sustentável de produtos madeireiros e não madeireiros; implantação de sistemas agroflorestais e silvo-pastoris que contemplem o plantio de, no mínimo, 50 indivíduos de espécies arbóreas nativas por hectare; implantação de florestas comerciais em áreas contíguas aos remanescentes de vegetação nativa para a minimização de efeito de borda; manejo de remanescentes florestais para controle de espécies competidoras, especialmente espécies exóticas invasoras.

Tais atividades devem ser realizadas por proprietários ou possuidores que atendam aos requisitos estabelecidos pela Secretaria do Meio Ambiente do Estado de São Paulo. No modelo atualmente em vigor, não é possível que os particulares proponham modelos alternativos de PSA, de forma que a única maneira de receber pagamentos por serviços ambientais é adequar-se às modalidades previstas na legislação.

O próprio Estado, por meio da Secretaria do Meio Ambiente, mapeia as regiões em que, por sua análise discricionária, poderão ser recebedoras de PSA. São consideradas as características geográficas, as necessidades específicas da região e da comunidade e as modalidades de serviços ambientais cabíveis. Em seguida, é editada uma Resolução estabelecendo as áreas prioritárias para a execução, os critérios de elegibilidade e priorização dos participantes, os critérios para a aferição dos serviços, os critérios para o cálculo dos valores e os prazos mínimos e máximos para a celebração dos contratos. 
Em razão da fase embrionária do PSA no Estado, foram editadas, até o

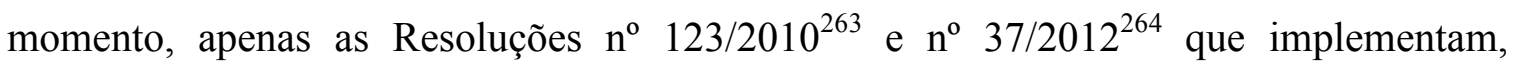
respectivamente, o Projeto Mina D’Água e o Projeto de Pagamento por Serviços Ambientais para as Reservas Particulares do Patrimônio Natural (PSA/RPPN). Embora ainda tímida, a iniciativa é importante não apenas sob o ponto de vista ambiental, mas também sob o social, uma vez que o Estado tem focado em comunidades carentes.

Em parceria com a Secretaria do Meio Ambiente, o Banco Mundial ${ }^{265}$ tem contribuído com os estudos iniciais do PSA no Estado de São Paulo. Está em fase de elaboração nos Municípios de Guapiara e Ibiúna um Plano de Avaliação de Impacto que avaliará a cobertura vegetal do Estado, as formas de uso das nascentes, as formas de contribuição dos beneficiários do PSA, os ganhos ambientais do projeto e os tipos de beneficiários.

O Projeto Mina D’Água tem como objetivo a proteção de nascentes e mananciais de abastecimento público. Envolve prefeituras, proprietários ou possuidores, a Secretaria do Meio Ambiente e agentes financeiros (Banco do Brasil e Fundo Estadual de Prevenção e Controle da Poluição).

Para o mapeamento das áreas onde se pretende implementar o PSA, dividiu-se o Estado de São Paulo em 21 Unidades de Gerenciamento de Recursos Hídricos (UGRHI), selecionando-se apenas um Município por unidade. Cada município contemplado passa a receber orientação técnica da Secretaria do Meio Ambiente para que seja preparado e publicado um edital com as regras municipais do PSA.

Somente após a publicação desse edital e desde que sejam obedecidas todas as suas exigências e condicionantes, é que os particulares podem buscar seu registro no Projeto.

\footnotetext{
${ }^{263}$ SÃO PAULO. Secretaria do Meio Ambiente. Resolução no 123, de 23 de dezembro de 2010. Disponível em: <http://www.ambiente.sp.gov.br/legislacao/resolucoes-sma/resolucao-sma-123-2010/>. Acesso em: 31 março 2014.

${ }^{264}$ SÃO PAULO. Secretaria do Meio Ambiente. Resolução no 37, de 5 de junho de 2012. Disponível em: $<$ http://www.ambiente.sp.gov.br/legislacao/resolucoes-sma/resolucao-sma-37-2012/>. Acesso em: 31 março 2014.

${ }^{265}$ As informações foram obtidas em entrevista com os funcionários do Banco Mundial em abril de 2013.
} 
Daí nota-se que o Estado e os municípios atuam em conjunto. Ao primeiro, cabe o fornecimento de apoio técnico, capacitação, planejamento e monitoramento, apoio técnico aos particulares e o fornecimento de recursos financeiros. Aos últimos, compete a seleção das áreas prioritárias, a definições das ações a serem executadas, a contratação dos serviços ambientais, o acompanhamento em campo e o monitoramento.

Essa relação entre Estado e Municípios é formalizada por um convênio. Paralelamente, são firmados outros contratos, na forma como se segue:

a) A Prefeitura firma um contrato com o Fundo Estadual de Prevenção e Controle da Poluição (FECOP) para o recebimento das verbas do PSA e o repasse aos participantes do projeto;

b) A Prefeitura e o Banco do Brasil firmam contrato para a criação de uma conta bancária, onde serão depositados os valores dos pagamentos;

c) A Prefeitura e os participantes firmam contrato para a definição dos direitos e obrigações, bem como para o recebimento das verbas do PSA.

É possível notar que o arranjo institucional do PSA é complexo, o que pode representar dificuldades aos funcionários e particulares envolvidos, principalmente nos Municípios menos estruturados.

O Projeto Mina D’Água é voltado para proprietários rurais conservacionistas, em especial o agricultor familiar. Trata-se de clara medida de incentivo a práticas conservacionistas, com forte viés social. Bem por isso, as barreiras impostas pela burocracia devem ser reduzidas e o Projeto deve ser amplamente divulgado, de forma a abranger o maior número possível de beneficiários.

O valor do pagamento aos beneficiários, tal como previu a Resolução $n^{\circ}$ 123/2010, leva em consideração o custo de oportunidade da região, a proteção da nascente, o estágio de regeneração da vegetação, a população atingida, a vazão da nascente e sua localização. 
Nos moldes atuais do Projeto ${ }^{266}$, cada beneficiário pode pleitear pagamento por, no máximo, 4 nascentes. Para cada nascente, o valor máximo a ser pago é de R\$ 300,00. Criou-se, ainda, um limite de 150 nascentes por Município.

Os recursos do PSA são originários do FECOP que, por sua vez, recebe verbas do orçamento do Governo Estadual. Adicionalmente, na forma como prevê a Lei Estadual $n^{\circ} 11.160 / 2002^{267}$, em seu artigo $2^{\circ}, X$ :

Art. $2^{\circ}$ Constituem receitas do FECOP: (...) X - doações de pagadores de serviços ambientais, efetuadas com a finalidade específica de remunerar serviços ambientais no âmbito dos projetos desenvolvidos pelo Poder Público.

Ou seja, não há regra específica para a definição do montante a ser destinado ao PSA, embora, atualmente, o FECOP já conte com aproximadamente R $\$ 3,5$ milhões ${ }^{268}$.

Por todo o exposto, é possível concluir que o Estado de São Paulo já conta com um sistema de PSA, embora esteja restrito a serviços florestais. O sistema ainda deverá se desenvolver para que outros serviços ambientais sejam abrangidos, para que o Estado deixe de ser o único comprador de serviços ambientais e para que iniciativas voluntárias possam sejam reconhecidas e elegíveis.

Por fim, um último aspecto que merece ser tratado quanto à experiência do Estado de São Paulo com o PSA refere-se à contraprestação do Estado pelos serviços ambientais prestados pelos particulares. Além da transferência de recursos financeiros aos beneficiários do PSA, poderiam ser oferecidos serviços de assistência técnica, tais como orientações de plantio, fornecimento de máquinas, fornecimento de água, adubação, mensuração, transporte etc., o que contribuiria para a regularização dos imóveis, aumento da produção, acesso a serviços de transporte, saúde, educação etc.

Tais serviços inserem-se no rol dos serviços públicos, assunto já discutido no Capítulo 4.

\footnotetext{
${ }^{266}$ As informações foram obtidas em entrevistas com os funcionários da Secretaria do Meio Ambiente do Estado de São Paulo responsáveis pela implementação do PSA, em abril de 2013.

267 SÃO PAULO. Lei Estadual $\mathrm{n}^{\mathrm{o}} 11.160$, de 18 de junho de 2002. Disponível em: $<$ http://www.al.sp.gov.br/norma/?id=138>. Acesso em: 31 março 2014.

${ }^{268}$ Valor informado pela Secretaria do Meio Ambiente do Estado de São Paulo em abril de 2013.
} 


\subsection{Doutrina favorável: principais argumentos sobre a concessão de incentivos ambientais}

A concessão de incentivos ambientais encontra defensores e críticos na doutrina nacional e internacional. Os argumentos favoráveis e contrários aos incentivos perpassam o Direito e visitam a Economia, a Filosofia, a Ética e a Sociologia, dentre outras ciências, demonstrando diferentes interações entre o homem e os meios bióticos e abióticos.

David Dapice sustenta que os economistas, em regra, desejam que a natureza seja utilizada de forma eficaz para satisfazer as vontades humanas, enquanto os ambientalistas querem que a natureza permaneça sagrada e segura ${ }^{269}$.

É importante notar que os incentivos ambientais podem propiciar receitas financeiras para práticas preservacionistas, o que significa a redução dos custos daqueles que preservam o meio ambiente. Isso vale nos cenários local, regional, nacional e internacional.

Com isso, a atividade de preservação deixa de ser apenas um ônus ou um dever legal e passa a ser uma atividade econômica em si, para fins de obtenção de receita. Ela traz externalidades ${ }^{270}$ positivas e possibilita a remuneração de uma atividade digna e sustentável.

\footnotetext{
269 DAPICE, David. Thinking about the future: the complementary roles of economists and environmentalists. In: GOODWIN, Neva R. (Editor). As if the future mattered: translating social and economic theory into human behavior. Ann Arbor: University of Michigan Press, 1996, p. 172. Quanto ao tema, o autor explica: "Economists want nature to be used efficiently to satisfy existing human wants, while environmentalists want nature to be sacred and secure from human depoilment. Both have a vision of the future. However, one is impressed by the earth's fragility and need for caution and the other by the urgent needs of the present and the likehood that new solutions will be found to the problems that arise as economic growth proceeds".

${ }^{270}$ Quanto ao tema das externalidades, Luís Eduardo Schoueri explica: "No campo ambiental, é comum a referência à externalidade negativa: a atividade poluidora gera danos ambientais, que não são suportados por seus causadores; externalidade positiva, por outro lado, pode surgir quando uma empresa, para atender a seu mercado, exige de seus fornecedores a observância de práticas favoráveis ao meio ambiente" (SCHOUERI, Luís Eduardo. Op. cit., p. 236). Por sua vez, David Dapice define externalidade como aquilo que acontece quando você faz algo que traz um efeito não planejado em alguém e que não é absorvido pelo sistema de mercado. Tradução livre do autor desta Dissertação. Do original: "Economists explain externalities as what happens when you do something that has an unintended effect on somebody else and it is not captured within the market system" (DAPICE, David. Op. cit., p. 177).
} 
É preciso que a sociedade reconheça a importância econômica, social e ambiental dos grupos que protegem o meio ambiente. É nesse contexto que se insere a recompensa, o incentivo ambiental, que deve ser estendido para os casos em que há obrigação legal de proteção. Isso, aliás, dá mais efetividade às leis ambientais, historicamente ignoradas, em vista do tamanho continental do País, à precária estrutura de fiscalização etc.

Nesse contexto, o princípio do protetor-recebedor ${ }^{271}$ propõe o pagamento àqueles agentes cuja ação promove o incremento dos serviços ambientais prestados pela natureza, em que há um ganho ambiental para o proprietário e para a sociedade (nacional ou internacional), decorrentes de atividade onerosa ao proprietário ou posseiro.

O autor norte-americano Richard Stewart aponta a necessidade de superarmos a ideia de que é imoral estabelecer direitos privados sobre recursos ambientais, principalmente se considerarmos que se tratam de permissões temporárias, e não propriamente direitos infindáveis ${ }^{272}$.

$\mathrm{Na}$ mesma linha, Norberto Bobbio ensina que o Estado deixou sua função "garantista" e passou a desenvolver papel "dirigista", encontrando no Direito uma ferramenta de controle social, no sentido estrito da palavra, para o fim de direção social.

Segundo Norberto Bobbio, o Direito é capaz de direcionar a sociedade pelo uso de incentivos, de forma a promover a realização de atos socialmente desejáveis ${ }^{273}$. A função estatal deixa de ser exclusivamente protetora e repressiva, passando a assumir papel também promocional.

\footnotetext{
${ }^{271}$ Sobre o princípio do protetor-recebedor, Ana Maria de Oliveira Nusdeo explica: "O princípio do protetor-recebedor (...) propõe o pagamento àqueles cuja ação promove o incremento dos serviços ambientais prestados pela natureza. (...) trata de retirar da esfera daquele que preserva, total ou parcialmente, os custos de preservação, podendo chegar mesmo a permitir que aufira algum ganho com a proteção" (NUSDEO, Ana Maria de Oliveira. Pagamento por serviços ambientais... cit., p. 137-138).

${ }^{272}$ BREGER, Marshall J.; ELLIOTT, E. Donald; HAWKINS, David; STEWART, Richard R. Op. cit., p. 466.

${ }^{273}$ BOBBIO, Norberto. Op. cit., p. XII.
} 
Como relata Peter H. May, é positiva a multiplicação das iniciativas de utilização de instrumentos econômicos para direcionar a atuação das forças de mercado em sentido favorável à proteção ambiental e ao uso sustentável dos recursos naturais ${ }^{274}$. De acordo com o autor, tais iniciativas têm corrigido falhas de mercado e estimulado a concessão de incentivos para o uso sustentável dos recursos naturais e a proteção ambiental $^{275}$.

Werner Grau Neto reforça o raciocínio ao anotar que a mecânica de incentivos induz o mercado ao exercício de atividades sustentáveis, em detrimento das atividades menos adequadas ao mote da sustentabilidade ${ }^{276}$.

Na mesma linha, Nick Hanley, Jason Shogren e Ben White relatam que o sistema de incentivos tem sido apontado pelos economistas norte-americanos, por décadas, como uma alternativa interessante, do ponto de vista do custo-benefício, em substituição ao sistema de comando e controle ${ }^{277}$. Para eles, a ideia é estimular o empreendedor a buscar, por sua conta, a melhor tecnologia de controle de poluição ao menor custo $^{278}$.

\footnotetext{
${ }^{274}$ MAY, Peter H. Introdução. In: AMARAL, Carlos; MAY, Peter H.; MILLIKAN, Brent; ASCHER, Petra (Orgs.). Instrumentos econômicos para o desenvolvimento sustentável da Amazônia brasileira. Brasília: Ministério do Meio Ambiente, 2005.2 Disponível em: <http://www.mma.gov.br/estruturas/168/_publicacao/168_publicacao30012009115059.pdf>. Acesso em: 31 março 2014.

${ }^{275}$ Idem, ibidem. Quanto ao tema, o autor anota: “(...) vêm se multiplicando as iniciativas de utilização de instrumentos econômicos para direcionar a atuação das forças de mercado em sentido favorável à proteção ambiental e ao uso sustentável dos recursos naturais. Essas iniciativas têm corrigido falhas de mercado, alterando a relação custo/benefício de determinadas atividades econômicas, em função dos impactos ambientais - ou socioambientais - negativos. Entre os instrumentos econômicos amplamente aplicados com essa finalidade, inclui-se a cobrança de impostos, taxas e outros encargos de atividades econômicas consideradas degradadoras do meio ambiente, bem como a concessão de incentivos para o uso sustentável dos recursos naturais e a proteção ambiental, levando em consideração os benefícios socioeconômicos e/ou ambientais - as externalidades positivas. Ademais, outras iniciativas têm surgido recentemente, como o emprego de certificados comercializáveis de emissão ou uso de recursos naturais que envolvem transações entre atores privados, sempre dentro dos padrões ou limites estabelecidos pelo poder público".

${ }^{276}$ GRAU NETO, Werner. Op. cit., p. 24.

${ }^{277}$ HANLEY, Nick; SHOGREN, Jason; WHITE, Ben. Environmental economics in theory and practice. New York: Oxford University Press, 1997, p. 58. Quanto ao tema, os autores citam: "Incentive systems have been promoted by economists for decades as a cost-effective alternative to technological restrictions and other forms of inflexible command-and-control environmental regulations. The idea behind economic incentives is to raise the cost of environmental shirking while allowing the producer the flexibility to find the least-cost pollution control strategy himself. By increasing the cost of shirking, the producer has a private incentive to provide the socially optimal level of pollution control".

${ }^{278}$ Idem, ibidem.
} 
A concessão de incentivos, para Nick Hanley, Jason Shogren e Ben White, ainda permite a distribuição dos custos e benefícios entre os membros da sociedade, garantindo equidade e justiça no tratamento da Administração Pública ${ }^{279}$.

Outro autor norte-americano, Howard A. Latin, defende que os legisladores deveriam aprender a fazer melhor uso de incentivos, a fim de encorajar o comportamento planejado pelas normas regulatórias ${ }^{280}$. De acordo com a sua opinião, há uma discrepância entre as metas ambientais e os resultados efetivamente alcançados, o que não pode ser corrigido, simplesmente, pela edição de novas normas. Seria necessária, para ele, a criação de incentivos ambientais ${ }^{281}$.

Eckard Rehbinder relata que, na União Europeia, o uso de instrumentos de incentivo tem inquestionável utilidade para as metas da política ambiental ${ }^{282}$.

Segundo ele, instrumentos econômicos e fiscais são utilizados, normalmente, para a redução de emissões, para a inclusão dos custos sociais da poluição nas contas do empreendedor e para proporcionar soluções com melhor custo-benefício do que a tradicional regulação por comando e controle ${ }^{283}$. Têm a vantagem de proporcionar mudanças estruturais, reduzir custos de transação para a adoção de novas tecnologias e são relativamente fáceis de corrigir quando novas informações são disponibilizadas ${ }^{284}$.

\footnotetext{
${ }^{279}$ Idem, p. 93.

${ }^{280}$ Regulatory Failure, Administrative Incentives and the New Clean Air Act. In: PERCIVAL, Robert; ALEVIZATOS, Dorothy (Editors). Law and the environment: a multidisciplinary reader. Temple University Press, Philadelphia, 1997, p. 328. Tradução livre do autor desta Dissertação. Do original: "Legislators must instead learn to create agency and bureaucratic incentives that may indirectly encourage desired regulatory behavior (...). Agency managers must therefore also learn to develop incentive systems that will induce better regulatory performance".

${ }^{281}$ Idem, ibidem. Tradução livre do autor desta Dissertação. Do original: "I do not contend that attention to administrative incentives can solve all regulatory problems, but I believe Congress will continue to repeat past mistakes until it recognizes that the discrepancy between environmental goals and implementation cannot be remedied simply by drafting more and more detailed statutes. A realistic assessment of implementation constraints and related incentives is essential if legislators are to revitalize existing environmental protection programs and revelop effective new ones".

${ }^{282}$ REHBINDER, Eckard. Op. cit., p. 63. Tradução livre do autor desta Dissertação. Do original: "Charges and taxes are of undoubted utility for the implementation of Community environmental policy goals".

${ }^{283}$ Idem, p. 66. Tradução livre do autor desta Dissertação. Do original: "Generally speaking, governments use economic and fiscal instruments to provide incentives for the reduction of emissions, to introduce the social costs of pollution into sources' cost bills, and to achieve more cost-effective solutions than those obtainable through traditional command and control regulation".

${ }^{284}$ Idem, ibidem. Tradução livre do autor desta Dissertação. Do original: "Economic and fiscal instruments can promote smooth structural changes, can decrease transaction costs for finding new pollution control techniques, and are relatively easy to correct when new information becomes available".
} 
Todavia, chama atenção para o fato de que o uso de alguns instrumentos econômicos, tal como a imposição de taxas, pode trazer significativo impacto no orçamento dos países, uma vez que altera o fluxo de recursos do governo ${ }^{285}$.

Myrick Freeman III, por sua vez, aponta que o sistema de incentivos, em especial aquele baseado na instituição de taxas em atividades poluentes e no comércio de permissões, tem uma relação de custo-benefício mais benéfica do que o sistema de comando e controle ${ }^{286}$.

A. Mitchell Polinsky, professor da Stanford Law School, faz apontamento no mesmo sentido ao afirmar que as normas legais que criam incentivos contribuem com comportamentos mais eficientes de pessoas e empresas ${ }^{287}$.

\subsection{Doutrina desfavorável: principais argumentos sobre a concessão de incentivos ambientais}

A ideia de remuneração por serviços ambientais ou por qualquer forma de proteção ao meio ambiente enseja críticas por parte daqueles que a consideram uma tendência à mercantilização e à privatização da natureza.

É possível que se argumente, por exemplo, que um sistema de incentivos favorecerá apenas grandes grupos, como no caso do mercado de carbono, em que os projetos são formulados em áreas extensas, envolvendo mercados mais maduros e intermediários sofisticados.

Pode-se, também, apontar a desnecessidade de se premiar aquele que nada fez além do cumprimento de uma obrigação legal. Da mesma forma, pode-se questionar o motivo da inexistência de incentivos para as demais obrigações trazidas pelo Direito.

\footnotetext{
${ }^{285}$ Idem, p. 63. Tradução do autor. Do original: “(...) these economic instruments may have significant impacts on the Member States' budgetary systems because they redirect the tax flow”.

${ }^{286}$ FREEMAN III, A. Myrick. Op. cit., p. 201. Quanto ao tema, os autores observam: “A system of pollution taxes or TDPs [tradable discharge permits] can make a major contribution to achieving costeffectiveness. If several sources are discharging into the environment, they will be induced to minimize the total cost of achieving any given reduction in pollution".

${ }^{287}$ POLINSKY, A. Mitchell. An introduction to law and economics. Boston: Little, Brown and Company, 1989, p. 130.
} 
Há quem sustenta, ainda, que a pessoa que escolhe conduzir determinada atividade econômica ou ser proprietário de um bem deve arcar com as consequências, custos e obrigações a eles correlatos.

Richard Stewart, embora defensor dos incentivos, aponta que a sociedade norteamericana faz três críticas de natureza ética aos incentivos, quais sejam: (i) passa-se a tratar o meio ambiente como um bem ou um produto, desconsiderando os valores não econômicos que possam existir; (ii) valorizam-se apenas interesses individuais, sem que a coletividade seja contemplada e (iii) confere-se o direito de poluir ${ }^{288}$.

Em raciocínio próximo, Lia Helena Monteiro de Lima Demange entende que o pagamento por serviços ecossistêmicos a particulares pode configurar uma falta de respeito à natureza ${ }^{289}$. Ela reporta que tal iniciativa, quando oriunda de mercados criados pela iniciativa privada, além de ameaçar a natureza, atribui valor monetário aos benefícios que a natureza traz à humanidade e trata a natureza como um produto ${ }^{290}$.

Todavia, entende que o pagamento por serviços ambientais pode assumir três formas distintas: (i) privada ${ }^{291}$; (ii) voluntária ${ }^{292}$ e (iii) regulatória ${ }^{293}$. No primeiro caso, cria-se um mercado pela iniciativa privada para a comercialização de serviços ecossistêmicos $^{294}$.

\footnotetext{
${ }^{288}$ STEWART, Richard B. Economic Incentives... cit., p. 197-199.

289 DEMANGE, Lia Helena Monteiro de Lima. The principle of resilience. Pace Environmental Law Review. v. 30, $\mathrm{n}^{\circ} 2,2013$, p. 799. Quanto ao tema, a autora aponta: "The theory of private payment for ecosystem services contains several aspects that evince lack of respect for nature. Besides threatening nature as a requirement for creating markets by private initiative, by attributing a monetary value to the benefits nature brings to humankind, the model for commercialization of ecosystem services unavoidably treats nature as a product".

${ }^{290}$ Idem, ibidem.

${ }^{291}$ Idem, ibidem. Tradução livre do autor desta Dissertação. Do original: "private payment for ecosystem services".

${ }^{292}$ Idem, p. 802. Tradução livre do autor desta Dissertação. Do original: "voluntary payment for ecosystem services".

${ }^{293}$ Idem, ibidem. Tradução livre do autor desta Dissertação. Do original: "regulatory payment for ecosystem services".

${ }^{294}$ Idem, p. 799.
} 
$\mathrm{Na}$ modalidade voluntária, os usuários dos serviços ambientais propõem-se a pagar por tais serviços voluntariamente ${ }^{295}$. Por fim, na modalidade regulatória, normas jurídicas de regulação criam a obrigação de preservar o ecossistema em determinados locais ${ }^{296}$.

Para Lia Helena Monteiro de Lima Demange, as modalidades privada e voluntária deixam desprotegidas as espécies e as funções ecológicas que não são diretamente úteis ao homem, mas que são importantes para manter o equilíbrio do ecossistema $^{297}$.

Também contrário ao tratamento do meio ambiente pela lógica de mercado, Enrique Leff critica:

\begin{abstract}
A economia ecológica lança um olhar crítico sobre a degradação ecológica e energética resultante dos processos de produção e consumo, tentando situar o intercâmbio econômico dentro do metabolismo geral da natureza. No entanto, a produção continua guiada e dominada pela lógica do mercado. A proteção do ambiente é considerada como um custo e condição do processo econômico, cuja 'sustentabilidade' depende das possibilidades de valorização da natureza. No entanto, o questionamento da economia a partir da ecologia não tem levado à desconstrução da racionalidade econômica dominante e a fundar uma nova teoria da produção nos potenciais da natureza e nos sentidos das culturas ${ }^{298}$.
\end{abstract}

Enrique Leff propõe uma "racionalidade ambiental" que articule "as diversas ordens culturais e esferas do saber, indo além das estruturas lógicas e dos paradigmas do conhecimento" ${ }^{\text {299 }}$. Questiona, além disso, o modelo atual de coisificação do ser e a superexploração da natureza ${ }^{300}$.

Luís Eduardo Schoueri, referindo-se à utilização de normas tributárias de caráter indutor no Direito Ambiental, aponta um efeito indesejado: a "monetarização do direito ambiental". Para ele, quando utilizado o instrumento tributário com efeito indutor, o

\footnotetext{
${ }^{295}$ Idem, p. 802. Quanto ao conceito, a autora aponta: “when service users voluntarily propose to pay for the ecosystem service".

${ }^{296}$ Idem, ibidem. Quanto ao conceito, a autora aponta: "when the trading program is used as a tool to encourage compliance with regulations that oblige the preservation of the ecosystem on certain parcels of land".

${ }^{297}$ Idem, ibidem.

${ }^{298}$ LEFF, Enrique. Racionalidade ambiental: a reapropriação social da natureza. Trad. Luís Carlos Cabral. Rio de Janeiro: Civilização Brasileira, 2006, p. 134.

${ }^{299}$ Idem, p. 25.

${ }^{300}$ Idem, p. 15.
} 
contribuinte já não mais é visto como alguém que gera danos, mas como alguém que paga a conta e, por isso, legitimado a usar ou consumir bens de natureza ambiental ${ }^{301}$.

Para ele, ainda, a consequência, a médio prazo, seria a redução de sua propensão a evitar a prática danosa ao meio ambiente, além da própria perda de consciência ambiental $^{302}$.

Eckard Rehbinder alerta para o fato de que alguns incentivos, tais como instrumentos econômicos, podem resultar em regulação excessiva do mercado e causar conflitos entre setores e agentes econômicos ${ }^{303}$.

Por fim, vale notar que ainda não há jurisprudência assentada sobre a concessão de incentivos ambientais. Verifica-se, todavia, que os tribunais brasileiros continuam apegados ao papel repressivo do Direito, inclusive em casos de pequenos delitos. É o que se verifica da análise dos julgados abaixo, todos do Superior Tribunal de Justiça:

\begin{abstract}
Na hipótese, não há como reconhecer a mínima ofensividade tampouco o reduzido grau de reprovabilidade da conduta, aptos a ensejarem a aplicação do referido princípio, visto que o paciente agiu com razoável periculosidade social ao invadir a residência da vítima, após o arrombamento da janela, e subtrair a quantia de R \$70,00 (setenta reais). Não obstante o valor subtraído, o modus operandi evidencia a inequívoca necessidade de repressão da conduta (STJ, $H C \mathrm{n}^{\circ}$ 205.730-RS, rel. Ministro Haroldo Rodrigues, j. 23.08.2011) 304 .
\end{abstract}

Na hipótese, não há como reconhecer a mínima ofensividade tampouco o reduzido grau de reprovabilidade da conduta, aptos a ensejarem a aplicação do referido princípio, visto que o recorrente subtraiu aproximadamente 14 canos de ferro de propriedade do Governo do Distrito Federal - Parque ecológico do Riacho Fundo, após serrar e arrancar os referidos objetos do suporte do alambrado de ferro que cerca o parque, res furtiva essa posteriormente avaliada em R\$ 100,00. Não obstante o valor atribuído à coisa subtraída, o modus operandi da conduta e o dano causado à coletividade e ao Poder Público evidenciam a inequívoca necessidade de repressão penal (STJ, Recurso em $H C$ $\mathrm{n}^{\mathrm{o}}$ 21.523-DF, rel. Ministro Haroldo Rodrigues, j. 22.08.2011) ${ }^{305}$.

\footnotetext{
${ }^{301}$ SCHOUERI, Luís Eduardo. Op. cit., p. 239.

${ }^{302}$ Idem, ibidem.

${ }^{303}$ REHBINDER, Eckard. Op. cit., p. 58. Quanto ao ponto, o autor relata: "economic and fiscal instruments are not a panacea. Many problems presented by direct regulation must also be solved when applying charges or taxes. Furthermore, because they enable the regulator to blur the distinction between regulation and non-regulation, charges and taxes may result in overregulation and aggravate conflicts between different economic agents, economic sectors, and Member States".

Disponível em:

$<$ https://ww2.stj.jus.br/revistaeletronica/ita.asp?registro=201101009777\&dt_publicacao=26/10/2011>. Acesso em: 31 março 2014.

${ }^{305}$ Disponível em:

$<$ https://ww2.stj.jus.br/revistaeletronica/ita.asp?registro=200701445932\&dt_publicacao=26/10/2011 $>$.

Acesso em: 31 março 2014.
} 


\subsection{Da necessidade de análises de custo-benefício nas políticas públicas ambientais}

Percebeu-se, de acordo com os dois itens anteriores, que há fundamentados argumentos contrários e favoráveis à concessão de incentivos. Tal fato se deve à pluralidade de formas de se encarar a questão, bem como à existência de diferentes caminhos para se garantir a proteção do meio ambiente.

Sendo assim, as políticas públicas ambientais podem utilizar instrumentos do tradicional sistema de comando e controle ou, então, valerem-se de mecanismos de estímulo. O importante é trazer resultados que sejam benéficos ao meio ambiente, à economia e à sociedade, ou seja, que garantam a sustentabilidade.

É possível, portanto, que cada situação seja analisada individualmente. Para tanto, a doutrina recomenda a elaboração de análises de custo-benefício.

Para Myrick Freeman III, a análise de custo-benefício é premissa básica para que haja um aumento do bem estar dos indivíduos que compõem a sociedade ${ }^{306}$.

Lia Helena Monteiro de Lima Demange defende que a análise de custo-benefício deveria ser sempre realizada pelas instituições governamentais antes da promulgação de regulamentações importantes ${ }^{307}$. Segundo ela, é necessária a contabilidade dos efeitos quantitativos e qualitativos de uma regulação, na qual as razões da iniciativa devem ser explicadas sempre que os custos excederem os benefícios ${ }^{308}$.

É necessário que a sociedade seja informada das razões sobre as quais as políticas ambientais estão fundadas, até para que tenha condição de verificar se a Administração Pública está sendo eficiente em seus objetivos e responsabilidades.

\footnotetext{
${ }^{306}$ FREEMAN III, A. Myrick. Op. cit., p. 191.

307 Tradução livre do autor desta Dissertação. Do original: “The cost-benefit approach requires government agencies to conduct a cost-benefit analysis (CBA) before enacting major regulations" (DEMANGE, Lia Helena Monteiro de Lima. Op. cit., p. 736).

${ }^{308}$ Tradução livre do autor desta Dissertação. Do original: "CBA requires a quantitative and qualitative accounting of the effects of a regulation, in which the reasons for action must be explained when the costs exceed the benefits" (Idem, ibidem).
} 
Confirmando o raciocínio, Robert Paehlke explica que as formas de entender e valorizar a ecologia traz evidentes implicações políticas, o que ficou evidenciado nos anos recentes ${ }^{309}$. Para ele, ideias e valores, se compartilhados, podem estabelecer uma agenda política renovada ${ }^{310}$.

A análise de custo-benefício é uma importante ferramenta que pode ser utilizada não apenas para a demonstração dos motivos das decisões políticas, mas também para a demonstração da eficiência do governo ${ }^{311}$.

Pode, da mesma forma, contribuir para uma reflexão quanto aos esforços e gastos públicos com as diferentes questões ambientais. Evitam-se, com isso, gastos desnecessários com questões menores e omissões em casos importantes ${ }^{312}$.

Nick Hanley, Jason Shogren e Ben White anotam que a análise de custobenefício é necessária para compor uma base de dados e monitorar os resultados práticos das políticas adotadas ${ }^{313}$. Adicionalmente, reportam que as políticas públicas ambientais,

309 Environmental Values and Public Policy. In: VIG, Norman J.; KRAFT, Michael (Editors). Environmental policy: new directions for the twenty-first century. 4th ed. Washington, D.C.: CQ Press, 2006, p. 80. Quanto ao tema, o autor aponta: "The way we understand and value ecology clearly has very important political implications, and each of the questions posed above has gained in political salience in recent years".

${ }^{310}$ Idem, ibidem. Tradução livre do autor desta Dissertação. Do original: "Ideas and values, if widely shared, can establish a new political agenda".

${ }^{311}$ Lia Helena Monteiro de Lima Demange explica que a eficiência é um termo empregado por economistas para designar transações econômicas que geram benefícios sociais superiores aos seus custos. Tradução live do autor da Dissertação. Do original: "Efficiency is the term employed by economists to designate economic transactions that generate greater societal benefits than costs" (DEMANGE, Lia Helena Monteiro de Lima. Op. cit., p. 736). Sobre o assunto, Nick Hanley, Jason Shogren e Ben White reportam que a eficiência é almejada porque implica no alcance dos objetivos do legislador ao menor custo possível (HANLEY, Nick; SHOGREN, Jason; WHITE, Ben. Op. cit., p. 92).

${ }^{312}$ Lia Helena Monteiro de Lima Demange destaca que a análise de custo-benefício não deve ser o único instrumento utilizado para a busca da eficiência do governo, pois há outros pontos a serem considerados. Para a autora, a análise de custo-benefício é muito focada em resultados imediatos, o que prejudica uma análise de longo prazo. Propõe, em razão dessa realidade, que haja uma ponderação entre os resultados da análise de custo-benefício, a opinião pública e os valores de proteção ambiental positivados na ordem normativa. Tradução live do autor desta Dissertação. Do original: “(...) the CBA is not sufficient to address governmental efficiency because it is too focused on short-term outcomes. Its techniques for discounting the future, its limitations on predicting the benefits of protective measures (which include both protective regulation and adoption of adaptive management), and its overestimation of the costs of environmental protection prevent it from being taken as a complete tool to address long-term governmental efficiency. (...) The need for combining CBA with other decision-making approaches also appeals as a matter of justice. (...) the administrative organ has to weigh the experts' opinion (represented by the result of the CBA) with input from public participation and with environmental conservation values recognized by estatute", (DEMANGE, Lia Helena Monteiro de Lima. Op. cit., p. 742).

${ }^{313}$ HANLEY, Nick; SHOGREN, Jason; WHITE, Ben. Op. cit., p. 95. 
notadamente aquelas que se valem de incentivos, devem considerar as seguintes condicionantes: (i) existência de informações sobre tecnologias, instituições e alternativas para o controle de poluição em diferentes cenários econômicos e geográficos; (ii) capacidade administrativa e comprometimento do governo; (iii) sistema jurídico eficiente; (iv) mercado competitivo e maduro e (v) viabilidade política ${ }^{314}$.

Ainda, explicam que os custos e benefícios ambientais podem ser quantificados de duas maneiras: método direto e método indireto. Pelo primeiro método, analisam-se diretamente com as pessoas suas preferências quanto ao meio ambiente. Para tanto, podem ser questionados, por exemplo, (i) qual seria o valor máximo que elas pagariam para aumentar a qualidade do meio ambiente e (ii) qual seria o valor mínimo que elas aceitariam como compensação para renunciar ao aumento da qualidade do meio ambiente ${ }^{315}$.

Também pode ser questionado às pessoas sobre (i) o valor máximo que elas pagariam para evitar uma diminuição da qualidade do meio ambiente e (ii) o valor mínimo que elas receberiam para aceitar tal redução ${ }^{316}$.

No método indireto, considera-se o comportamento das pessoas em determinados mercados. Por exemplo, o valor que uma pessoa pode dar para ter a oportunidade de caminhar em uma montanha é o valor por ela gasto para chegar até o local e realizar a caminhada ${ }^{317}$.

\footnotetext{
${ }^{314}$ Idem, p. 95-97.

315 Tradução livre do autor desta Dissertação. Do original: "Valuation methods are usually divided into two approaches: direct methods and indirect methods. Direct methods seek to infer individuals' preferences for environmental quality directly, by asking them to state their preferences for the environment. In contingent valuation surveys, for example, this might consist of asking people for either their maximum willingness to pay (WTP) for an increase in environmental quality or their minimum willingness to accept compensation (WTAC) to forgo such an increase" (Idem, p. 383).

316 Tradução livre do autor desta Dissertação. Do original: "Respondents might instead be asked about their maximum WTP to avoid a decrease in environmental quality, or their minimum WTAC to accept this reduction" (Idem, ibidem).

${ }^{317}$ Tradução livre do autor desta Dissertação. Do original: “An alternative to contingent valuation, and more general stated preference approaches, is to infer the value that individuals place on the environment from their behavior in related markets. For example, the value an individual places on the opportunity to walk in a mountain area may be revealed by what that individual spends to get to that area" (Idem, p. 404).
} 
Nick Hanley, Jason Shogren e Ben White também relatam que a análise dos custos de viagens cujo destino são áreas de recreação ao ar livre é uma das mais antigas formas de quantificação ambiental pelo método indireto. $\mathrm{O}$ método tem sido utilizado nos Estados Unidos e no Reino Unido para a valoração de benefícios não-econômicos da recreação ao ar livre, principalmente nos casos em que envolve parques nacionais e florestas públicas $^{318}$.

Sobre o cálculo de custos e benefícios, Myrick Freeman III defende que devem ser medidos os valores de tudo o que se ganha (benefícios) e do que se perde (custos) considerando as preferências daqueles que experimentam tais perdas e ganhos ${ }^{319}$. Para ele, políticas de proteção ambiental e controle de poluição só devem ser adotadas se os resultados valerem para os indivíduos considerados ${ }^{320}$.

Frente ao exposto, é inquestionável a necessidade de análises de custo-benefício para todas as políticas públicas ambientais existentes - ou aquelas em fase de projeto - no Brasil. Por certo, os valores não-econômicos também devem ser considerados, a fim de que se garanta a qualidade ambiental almejada pela sociedade.

\footnotetext{
${ }^{318}$ Idem, p. 404-405. Quanto ao ponto, Nick Hanley, Jason Shogren e Ben White registram: "This [travel cost model] is one of the oldest approaches to environmental valuation, proposed in a letter from Harold Hotelling to the US Forest Service in the 1930s, first used by Wood and Trice in 1958, and popularised by Clawson and Knetsh (1966). The method involves using travel costs as a proxy for the price of visiting outdoor recreational sites. (...) The method has been widely used in both USA and the UK for valuing the non-market benefits of outdoor recreation, especially recreation associated with national parks and public forests",

${ }^{319}$ Tradução livre do autor desta Dissertação. Do original: "We should measure the values of what we gain (the benefits) and what we lose (the costs) in terms of the preferences of those who experience these gains and losses" (FREEMAN III, A. Myrick. Op. cit., p. 192).

${ }^{320}$ Idem, ibidem.
} 


\section{CAPÍTULO 6 - O DIREITO INTERNACIONAL AMBIENTAL E A EXPERIÊNCIA DOS PAÍSES NA CONCESSÃO DE INCENTIVOS}

A abordagem do Direito Internacional Ambiental é importante para o presente trabalho porque foi justamente nesta seara - a internacional - que os mecanismos de incentivo ganharam força, em razão da inexistência, em muitos casos, de instrumentos de coerção que obrigassem ou garantissem o cumprimento dos tratados internacionais firmados entre os países.

Este Capítulo apresenta alguns exemplos de normas internacionais em que o mecanismo de incentivo é utilizado, bem como a opinião da doutrina estrangeira quanto aos incentivos ambientais e outros instrumentos do Direito Ambiental.

\subsection{Incentivos no Direito internacional Ambiental}

O sistema de encorajamento - uso de normas de estímulo, ou incentivos assume especial importância no âmbito internacional, uma vez que inexiste uma entidade supranacional de caráter ambiental competente para estabelecer regras e punições por danos ambientais.

Atualmente, no âmbito da ONU, há apenas uma agência denominada Programa das Nações Unidas para o Meio Ambiente (PNUMA, em inglês, United Nations Environment Programme), responsável por promover a conservação do meio ambiente e o uso eficiente de recursos no contexto do desenvolvimento sustentável ${ }^{321}$.

A agência foi estabelecida em 1972 e tem entre seus principais objetivos manter o estado do meio ambiente global sob contínuo monitoramento; alertar povos e nações sobre problemas e ameaças ao meio ambiente e recomendar medidas para melhorar a qualidade de vida da população sem comprometer os recursos e serviços ambientais das gerações futuras.

\footnotetext{
321 Disponível em: <http://www.onu.org.br/onu-no-brasil/pnuma/ $>$ e <www.unep.org $>$. Acesso em: 31 março 2014.
} 
Não se trata, portanto, de uma instituição com poderes decisórios, nem tampouco legislativos, o que restringe sua atuação na proteção do meio ambiente.

$\mathrm{Na}$ ausência de uma organização supranacional competente para estabelecer regras e punições por danos ambientais, põe-se a necessidade de que sejam criados mecanismos jurídicos alternativos de garantia e estímulo ao cumprimento das normas internacionais $^{322}$.

Uma das maneiras de se atingir o cumprimento das normas internacionais é a cooperação internacional. Nesse sentido, Rubens Capistrano Cacais registra que "a cooperação internacional se faz cada vez mais necessária, tanto na seara ambiental, transfronteiriça, quanto nos demais campos do direito",323.

Neste caso, é preciso que um Estado auxilie o outro, trabalhando em conjunto em determinado assunto de interesse de um ou de ambos os Estados ${ }^{324}$.

Trata-se de importante ferramenta do Direito Internacional, cada vez mais utilizada e respeitada na comunidade jurídica. Todavia, pode ser falha nos casos em que um ou mais Estados deixam de cooperar pela simples inexistência de estímulos ou sanções.

\footnotetext{
${ }^{322}$ Nick Hanley, Jason Shogren e Ben White apontam que, na ausência de uma autoridade internacional competente, são necessários acordos internacionais voluntários para a proteção da comunidade internacional. Tradução livre do autor desta Dissertação. Do original: "Given the lack of a competent international authority to interanalise internacional environmental spillovers, voluntary international agreements are necessary to safeguard the global commons" (HANLEY, Nick; SHOGREN, Jason; WHITE, Ben. Op. cit., p. 164).

${ }^{323}$ CACAIS, Rubens Capistrano. Cooperação internacional ambiental. In: MILARÉ, Édis; MACHADO, Paulo Affonso Leme (Org.). Direito ambiental: direito ambiental internacional e temas atuais. São Paulo: RT, 2011. p. 439.

324 Idem, ibidem.
} 
Francisco Rezek ainda anota outra dificuldade no Direito Internacional Ambiental:

Tais como as normas hoje vigentes no plano internacional sobre economia e desenvolvimento - que também respondem, em certa medida, a um direito humano de terceira geração -, as normas ambientais têm um tom frequente de 'diretrizes de comportamento' mais que de 'obrigações estritas de resultado', configurando desse modo aquilo que alguns chamam de soft law ${ }^{325}$.

Ou seja, segundo uma parcela da doutrina, as normas ambientais internacionais não passam de diretrizes de comportamento, o que significa que não trazem obrigações cogentes para os Estados. Neste caso, pode-se imaginar a dificuldade de se fazer cumprir, de toda a comunidade jurídica internacional, os compromissos ambientais assumidos nos acordos e tratados 326 .

Soma-se a isso o fato de que a adesão a tratados internacionais é voluntária pelos Estados, o que significa que alguns países podem não ser signatários e, consequentemente, não cumprir as regras internacionais estabelecidas.

Há que se mencionar, ainda, os casos em que determinada conduta tenha sido praticada em um Estado e causado danos em outro Estado, tal como ocorre com a poluição transfronteiriça. Se não houver uma organização supranacional para normatizar, fiscalizar e punir o Estado que causou o dano, e na ausência de normas internas que limitem este tipo de ocorrência no Estado infrator, corre-se o risco de se inviabilizar a solução jurídica do caso.

Com isso, diante das dificuldades supramencionadas e da necessidade de mecanismos alternativos, é importante que o Direito Internacional Ambiental estabeleça incentivos para garantir a proteção ambiental e a eficácia das normas internacionais.

\footnotetext{
${ }^{325}$ REZEK, Francisco. Direito Internacional Público. 13 ed. São Paulo: Saraiva, 2011, p. 281.

${ }^{326}$ Quanto ao tema, Francisco Rezek ainda ensina: “A falta aos deveres resultantes de sua qualidade de membro de uma organização internacional pode trazer ao Estado consequências peculiares, quais sejam, as sanções previstas pelo tratado constitutivo e aplicáveis pela própria organização, mediante voto num de seus órgãos. Essas assumem, usualmente, duas formas: a suspensão de determinados direitos e a exclusão do quadro" (REZEK, Francisco. Direito internacional público... cit., p. 306). Notar que, para temáticas ambientais, ainda não foi criada uma organização internacional, o que significa que as "consequências peculiares" apontadas pelo autor não poderiam ocorrer.
} 


\title{
6.2 Incentivos na Convenção sobre diversidade biológica
}

A Convenção sobre Diversidade Biológica ${ }^{327}$, assinada na cidade do Rio de Janeiro, em 1992, trouxe a possibilidade de serem constituídos direitos sobre os recursos genéticos (propriedade intelectual), como forma de equilibrar a relação entre os países detentores de biotecnologia e os países detentores de biodiversidade. Os objetivos principais da Convenção são, nos termos do artigo $1^{\circ}$,

\begin{abstract}
a conservação da diversidade biológica, a utilização sustentável de seus componentes e a repartição justa e eqüitativa dos benefícios derivados da utilização dos recursos genéticos, mediante, inclusive, o acesso adequado aos recursos genéticos e a transferência adequada de tecnologias pertinentes, levando em conta todos os direitos sobre tais recursos e tecnologias, e mediante financiamento adequado.
\end{abstract}

Seria possível, nos moldes tradicionais, que a mencionada Convenção delimitasse seus objetivos e estabelecesse sanções, caso não houvesse cumprimento daqueles. No entanto, demonstrando a evolução do Direito internacional Ambiental, em busca da eficácia das normas jurídicas internacionais de proteção aos direitos difusos, o tratado internacional criou incentivos.

Um dos incentivos que merece destaque é a possibilidade da obtenção de patentes - e, com isso, rendimentos econômicos com os royalties - sobre determinados recursos genéticos. Dessa forma, é incentivada a pesquisa e, respeitados os preceitos do Tratado, é possível uma repartição justa e equitativa dos benefícios oriundos da utilização dos recursos genéticos.

\footnotetext{
${ }^{327}$ Disponível em: <http://www.mma.gov.br/biodiversidade/convencao-da-diversidade-biologica>. Acesso em: 31 março 2014.
} 


\subsection{Incentivos na Convenção-Quadro das Nações Unidas sobre Mudança do Clima}

A Convenção-Quadro das Nações Unidas sobre Mudança do Clima ${ }^{328}$, por meio do Protocolo de Quioto $^{329}$ (assinado em 1997), previu mecanismos de mercado que possibilitaram o auferimento de renda para aqueles que reduzirem as emissões de gases causadores de efeito estufa.

É o caso, por exemplo, do Mecanismo de Desenvolvimento Limpo (MDL), previsto no artigo $12^{330}$ do referido Protocolo. O MDL permite que países em desenvolvimento façam projetos de redução de emissões e vendam os créditos de carbono a países desenvolvidos. Além da venda dos créditos, os países em desenvolvimento podem

\footnotetext{
${ }^{328}$ Disponível em: <http://www.mma.gov.br/clima/convencao-das-nacoes-unidas>. Acesso em: 31 março 2014.

${ }^{329}$ Disponível em: <http://www.mma.gov.br/clima/protocolo-de-quioto>. Acesso em: 31 março 2014.

${ }^{330}$ Cf. artigo 12 do Protocolo de Quioto. "Artigo 12. 1. Fica definido um mecanismo de desenvolvimento limpo. 2. O objetivo do mecanismo de desenvolvimento limpo deve ser assistir às Partes não incluídas no Anexo I para que atinjam o desenvolvimento sustentável e contribuam para o objetivo final da Convenção, e assistir às Partes incluídas no Anexo I para que cumpram seus compromissos quantificados de limitação e redução de emissões, assumidos no Artigo 3. 3. Sob o mecanismo de desenvolvimento limpo: (a) As Partes não incluídas no Anexo I beneficiar-se-ão de atividades de projetos que resultem em reduções certificadas de emissões; e (b) As Partes incluídas no Anexo I podem utilizar as reduções certificadas de emissões, resultantes de tais atividades de projetos, para contribuir com o cumprimento de parte de seus compromissos quantificados de limitação e redução de emissões, assumidos no Artigo 3, como determinado pela Conferência das Partes na qualidade de reunião das Partes deste Protocolo. 4. O mecanismo de desenvolvimento limpo deve sujeitar-se à autoridade e orientação da Conferência das Partes na qualidade de reunião das Partes deste Protocolo e à supervisão de um conselho executivo do mecanismo de desenvolvimento limpo. 5. As reduções de emissões resultantes de cada atividade de projeto devem ser certificadas por entidades operacionais a serem designadas pela Conferência das Partes na qualidade de reunião das Partes deste Protocolo, com base em: (a) Participação voluntária aprovada por cada Parte envolvida; (b) Benefícios reais, mensuráveis e de longo prazo relacionados com a mitigação da mudança do clima, e (c) Reduções de emissões que sejam adicionais as que ocorreriam na ausência da atividade certificada de projeto. 6. O mecanismo de desenvolvimento limpo deve prestar assistência quanto à obtenção de fundos para atividades certificadas de projetos quando necessário. 7. A Conferência das Partes na qualidade de reunião das Partes deste Protocolo deve, em sua primeira sessão, elaborar modalidades e procedimentos com o objetivo de assegurar transparência, eficiência e prestação de contas das atividades de projetos por meio de auditorias e verificações independentes. 8. A Conferência das Partes na qualidade de reunião das Partes deste Protocolo deve assegurar que uma fração dos fundos advindos de atividades de projetos certificadas seja utilizada para cobrir despesas administrativas, assim como assistir às Partes países em desenvolvimento que sejam particularmente vulneráveis aos efeitos adversos da mudança do clima para fazer face aos custos de adaptação. 9. A participação no mecanismo de desenvolvimento limpo, incluindo nas atividades mencionadas no parágrafo 3(a) acima e na aquisição de reduções certificadas de emissão, pode envolver entidades privadas e/ou públicas e deve sujeitar-se a qualquer orientação que possa ser dada pelo conselho executivo do mecanismo de desenvolvimento limpo. 10. Reduções certificadas de emissões obtidas durante o período do ano 2000 até o início do primeiro período de compromisso podem ser utilizadas para auxiliar no cumprimento das responsabilidades relativas ao primeiro período de compromisso" (Disponível em:

$<$ http://mudancasclimaticas.cptec.inpe.br/ rmclima/pdfs/Protocolo_Quioto.pdf $>$. Acesso em: 31 março 2014).
} 
contar com investimentos na própria elaboração do projeto de MDL, bem como a transferência de tecnologia e expertise.

Note-se que, uma vez assinada e ratificada a Convenção do Clima, todas as Partes deveriam ter suas emissões controladas, nos termos do que foi definido, sob pena de descumprimento do Tratado. Ocorre que, por certo, não é simples a alteração do funcionamento de todo um parque industrial, de uma política ambiental doméstica, de um sistema agropecuário, do tratamento do lixo, da eficiência energética, dentre outras mudanças possíveis e necessárias para uma redução nas emissões de gases de efeito estufa. Dessa forma, devido ao alto custo das mudanças e à sua complexidade, haveria um risco considerável de que o objetivo da Convenção não fosse alcançado.

Para que isso não ocorresse, valendo-se dos moldes tradicionais dos Tratados internacionais, poderiam ser criadas sanções, a serem aplicadas coercitivamente contra os países que descumprissem o acordo. Todavia, essa provavelmente não seria uma opção eficaz, já que, necessariamente, os países que deveriam reduzir suas emissões são grandes potências mundiais.

Neste raciocínio, restariam prejudicados os termos do acordo internacional, e seus resultados seriam insignificantes. Buscou-se, então, a criação de outro mecanismo com vistas ao cumprimento dos termos do tratado internacional. $\mathrm{O}$ resultado foi a previsão de incentivos, dentre os quais destacam-se os créditos de carbono.

Richard Stewart aponta a importância e o sucesso da estratégia adotada na Convenção e convoca a comunidade jurídica internacional para replicar o modelo em outros tratados internacionais ${ }^{331}$.

\footnotetext{
${ }^{331}$ STEWART, Richard B. Economic Incentives... cit., p. 228-229. Sobre o tema, o autor anota: "The FCCC [Framework Convention on Climate Change] and Kyoto Protocol are specially notable because they provide for the use of EIS [economic incentive system], in the form of internationally tradable greenhouse gas (GHG) emissions quotas and credits, to implement an international environmental agreement. (...) Given the long lead times necessary in order to build effective international and domestic measures and arrangements to limit GHG emissions, it is prudent to begin now to develop these measures and institutions as part of a 'learning by doing' strategy. The FCCC and Kyoto Protocol represent such a beginning”.
} 
Tratam-se, como se vê, de medidas incentivadoras para o cumprimento do acordo internacional, cujo escopo principal é a redução e a estabilização dos gases de efeito estufa em níveis que não prejudiquem a saúde humana e o meio ambiente.

\subsection{Experiência da Costa Rica}

A Costa Rica desenvolveu uma política de pagamento por serviços ambientais em 1996, como evolução dos esforços e instrumentos legais estabelecidos para a proteção florestal do país ${ }^{332}$. Dentre os instrumentos criados, destacam-se os Certificados de Abono Florestal (CAF), criados em 1986, que consistiam em títulos representativos de investimentos em projetos de reflorestamento, que podiam ser transacionados e utilizados no pagamento de impostos. Em 1995, o sistema foi ampliado, sendo criados certificados representativos de conservação florestal, os denominados Certificados de Proteção Florestal $^{333}$.

De acordo com Ana Maria de Oliveira Nusdeo, o PSA da Costa Rica foi previsto na Lei Florestal $\mathrm{n}^{\mathrm{o}}$ 7.575/1996, em que são definidos os serviços ambientais contemplados, envolvendo mitigação das emissões de gases de efeito estufa; proteção da água para uso urbano, rural ou hidroelétrico; proteção da biodiversidade para conservação e uso sustentável e a proteção de ecossistemas, formas de vida e beleza cênica natural, para fins turísticos e científicos ${ }^{334}$.

Ainda anota:

A política costa-riquenha caracteriza-se pelo pioneirismo na criação do instrumento de pagamento pelos serviços ambientais, que é decorrente da sua posição de frente na percepção da importância desses serviços, que geram benefícios a diversos usuários dos mesmos. Por isso, essa política caracterizase pelo forte papel de coordenação do Estado para alocar o pagamento dos beneficiários dos serviços aos provedores. É o Poder Público, portanto, quem promove os pagamentos e quem se dedica à captação de fundos, seja junto a beneficiários nacionais de serviços ambientais, seja em âmbito internacional ${ }^{335}$.

\footnotetext{
${ }^{332}$ NUSDEO, Ana Maria de Oliveira. Pagamento por serviços ambientais... cit., p. 61.

${ }^{333}$ Idem, ibidem.

${ }^{334}$ Idem, ibidem.

${ }^{335}$ Idem, p. 62.
} 
Portanto, a política de pagamento por serviços ambientais da Costa Rica tem sido utilizada como exemplo na comunidade internacional e representa um avanço no sistema de estímulo a boas práticas ambientais.

\subsection{Experiência dos Estados Unidos da América}

Neste item, serão apontadas as opiniões de profissionais, doutrinadores, instituições e pesquisadores norte-americanos quanto aos incentivos ambientais e à política ambiental doméstica dos Estados Unidos, para que sua experiência positiva possa ser replicada ou discutida no Brasil.

Em primeiro lugar, como registrado pelo próprio Congresso Americano, o sistema normativo ambiental dos Estados Unidos baseia-se, principalmente, no risco das atividades econômicas ou na tecnologia disponível ${ }^{336}$. Isso significa que, para a regulação do meio ambiente, leva-se em consideração o potencial de dano das atividades e seus impactos na qualidade de vida ou a disponibilidade do mercado em oferecer tecnologias que possam reduzir a poluição ${ }^{337}$.

Ambas as estratégias parecem ter vantagens e desvantagens e são aplicadas conforme a conveniência do tomador de decisão. Nesse sentido, o Congresso Americano registrou:

Both strategies have advantages and disadvantages and, although certain types of problems might be better suited to one approach, the choice of approach depends to a great extent on the values of the decisionmaker ${ }^{338}$.

\footnotetext{
${ }^{336}$ U.S. Congress, Office of Technology Assesment, Environmental Policy Tools: A User's Guide. OTAENV-634 (Washington, D.C.: U.S. Government Printing Office, September, 1995. In: PERCIVAL, Robert; ALEVIZATOS, Dorothy (Editors). Law and the environment: a multidisciplinary reader. Temple University Press, Philadelphia, 1997, p. 268. Tradução livre do autor desta Dissertação. Do original: "Over the last 25 years, Congress has followed two broad types of strategies for environmental regulation: 1) risk-based strategies and 2) technology-based strategies".

${ }^{337} \mathrm{Idem}$, ibidem. Quanto ao ponto, afirma-se: "In a risk-based strategy, the target that individual or groups of sources must meet is based on modeled or measured environmental quality. For example, stationary sources of air violate air quality standards in the vicinity of the facility. Under a technology-based strategy, the targets that sources must meet are based on technological capacity or potential to lower pollution, rather than a directly specified level of environmental quality. Under this type of strategy, the level of environmental protection is indirectly specified by the stringency of the abatement requirement. For example, sewage treatment plants are required to remove a percentage of the pollutants entering the facility".

338 Idem, ibidem.
} 
6.5.1 Experiência com o sistema da melhor tecnologia disponível (best available control technology system ou BAT)

Bruce Ackerman ${ }^{339}$, em sua obra sobre a necessidade de reforma da legislação ambiental americana na década de 1990, explica que o sistema norte-americano de regulação ambiental baseado na estratégia da tecnologia disponível recebeu a denominação de "best available control technology system" (BAT). As tecnologias eram determinadas por normas federais.

Cita o Clean Water Acts'BAT, pelo qual a agência ambiental americana adotava limites uniformes de efluentes para mais de 500 indústrias. A mesma estratégia foi utilizada no Clean Air Act para novas fontes de emissões industriais, novos carros e fontes de poluentes tóxicos industriais ${ }^{340}$.

A estratégia do BAT teve início na década de 1970. Todavia, tal como destaca Bruce Ackerman $^{341}$, não estimula os produtores a usarem a melhor técnica, mas apenas a seguir o que foi determinado pelas autoridades regulatórias. Não há um estímulo, por exemplo, para usar outra tecnologia e reduzir os níveis de emissão, já que eventuais investimentos adicionais não serão recompensados. Ou seja, em termos econômicos, é mais vantajoso utilizar a tecnologia já implantada e autorizada, mesmo havendo outra técnica menos impactante.

Há empresas cujo custo de redução de emissão é inferior a outras. Essas poderiam reduzir suas emissões e vender direitos de emissões para outras empresas. Mas, como as autorizações são vinculadas ao empreendedor e à sua atividade, e como a redução de poluição não gera o direito de comercializar a sobra, o que ocorre, na prática, é que todos acabam poluindo mais.

\footnotetext{
339 ACKERMAN, Bruce. Reforming Environmental Law: The Democratic Case for Market Incentives. Faculty Scholarship Series. Paper 141, 1998. Disponível em: $<$ http://digitalcommons.law.yale.edu/cgi/viewcontent.cgi?article=1140\&context $=$ fss_paper $>$. Acesso em: 31 março 2014.

${ }^{340}$ Idem, p. 178.

${ }^{341}$ Idem, ibidem.
} 
Para Bruce Ackerman, o uso de instrumentos de incentivo, tal como mecanismos de mercado ${ }^{342}$, não apenas economizaria bilhões de dólares por ano, como elevaria a eficiência da Administração Pública e contribuiria com o orçamento dos cofres públicos $^{343}$.

Estima que a substituição do sistema BAT, adotado para o controle da poluição do ar e da água nos Estados Unidos, para os mecanismos de mercado, poderia ter economizado mais de 15 bilhões de dólares ao ano ${ }^{344}$.

Vale ainda anotar que os mecanismos de mercado retirariam um grande trabalho dos órgãos públicos, uma vez que não seria necessária a análise pormenorizada das características de cada empreendimento, o estudo e o estabelecimento da tecnologia aplicável, a emissão de autorizações ou licenças etc. Paralelamente, o setor produtivo teria estímulos para reduzir, cada vez mais, os níveis de emissões e comercializar os direitos excedentes.

O esforço e os gastos para definir tecnologias e estudar cada caso concreto migraria das autoridades públicas para os industriais e seus engenheiros, permitindo que o Poder Público se preocupasse com questões mais complexas e importantes, tal como a fiscalização, a qualidade do meio ambiente, o estudo e estabelecimento dos níveis globais de poluição etc ${ }^{345}$.

\footnotetext{
${ }^{342}$ Tradução livre do autor desta Dissertação. Do original: "market incentives". Idem, p. 171.

${ }^{343}$ Tradução livre do autor desta Dissertação. Do original: "The creative use of market incentives will not only save billions of dollars each year, vastly improve administrative efficiency, and even help balance the budget. It will also vastly improve the quality of democratic debate about environmental values, allowing a wider public to address basic values that the present regulatory system obscures under a flood of technocratic mumbo-jumbo". Idem, ibidem.

${ }^{344}$ Idem, p. 177.

${ }^{345}$ Bruce Ackerman registra: "A system of marketable permits, then, not only promises to save American billions of dollars a year, to reward innovative improvements in existing cleanup techniques and to eliminate the BAT system's penalty on new, productive investment. It also offers formidable administrative advantages. It relieves agencies of the enormous information-processing burdens that overwhelm them under the BAT system; it greatly reduces litigation and delay; it offers a rich source of budgetary revenue in a period of general budgetary stringency; and it enforces agencies to give new importance to the critical business of enforcing the law in a way that America's polluters will take seriously". Idem, p. 183.
} 
Bruce Ackerman aponta, resumidamente, os principais pontos negativos do sistema BAT - os quais, afirma, seriam evitados em um sistema de mecanismos de mercado $^{346}$ : (i) desperdiçam-se bilhões de dólares, seja pelos gastos da Administração Pública, seja pelo custo de oportunidade de aplicação de outras técnicas ou tecnologias; (ii) fere-se a isonomia pela imposição, em alguns casos, de restrições maiores aos novos empreendimentos; (iii) limita-se o desenvolvimento de novas tecnologias, possivelmente mais eficazes, de desenvolvimento mais limpo; (iv) desconsideram-se as diferenças entre as indústrias e seus processos produtivos, o que acaba gerando litígios e, consequentemente, gastos públicos e privados com ações judiciais (em vez de se gastar apenas com cumprimento das normas, gasta-se na discussão dos padrões); (v) limita-se a atividade econômica, já que os órgãos públicos acabam não tendo condições de regular o grande número de atividades industriais do mercado.

Pelo exposto, os mecanismos de mercado propostos reduziriam os gastos públicos, contribuiriam com o aumento da eficiência da Administração Pública e garantiriam resultados mais positivos sob o ponto de vista ambiental. Todavia, algumas dificuldades seriam enfrentadas para a sua implantação, tais como: (i) definição do número adequado de autorizações e licenças para cada local; (ii) criação de um sistema eficaz para auditar as empresas e cruzar os dados de sua poluição com as autorizações e licenças que possuem; (iii) criação de um sistema eficaz de venda e compra das autorizações e licenças, de forma a evitar fraudes e mercados paralelos e (iv) equilíbrio entre os incentivos concedidos e as penas aplicáveis pelo descumprimento das normas e limites.

\subsubsection{Experiência com incentivos econômicos}

Também na década de 1990, mais especificamente em 23 de abril de 1990, a Administrative Conference of the United States ${ }^{347}$ reuniu-se para discutir sobre incentivos econômicos na seara ambiental, na oportunidade do debate sobre as emendas à Clean Air

\footnotetext{
${ }^{346}$ Idem, p. 173.

347 A Administrative Conference of the United States é uma agência federal americana independente encarregada de promover reformas e melhoramentos nos processos administrativos e regulatórios. Parte dos trabalhos desenvolvidos volta-se à organização de colóquios e discussões. Para mais detalhes, cf. BREGER, Marshall J.; ELLIOTT, E. Donald; HAWKINS, David; STEWART, Richard R. Op. cit., p. 463.
} 
Act americana. Os discursos foram gravados, editados e transformados em obra doutrinária $^{348}$.

Participaram Richard Stewart, como Assistant Attorney General for the US Department of Justice, Environmental and Natural Resources Division; Donald Elliot, na condição de General Counsel of the Environmental Protection Agency e David Hawkins, como Natural Resources Defense Counsel.

Richard Stewart explica que o modelo de comando e controle implantado no Direito Ambiental norte-americano foi traçado em um momento de urgência de medidas ambientais e trouxe alguns ganhos ${ }^{349}$. Ou seja, não configurou um sistema inócuo. Todavia, um novo modelo era necessário, para que os resultados pudessem ser ainda melhores.

O autor ensina que o sistema de comando e controle estabelece uma regulação que exige ações específicas de uma entidade reguladora, normalmente mediante a definição de padrões tecnológicos de poluição ou segurança (a melhor tecnologia disponível ou best available technology) ${ }^{350}$.

$\mathrm{Na}$ opinião do autor, a proliferação de medidas de comando e controle não é o caminho mais adequado e funcional, a longo prazo, de lidar com as questões ambientais. É uma opção cara e traz imperfeições. Exige-se dos órgãos reguladores a definição de regras para centenas de milhares de indústrias, o que resulta em soluções uniformes e padronizadas, a despeito das grandes diferenças operacionais das indústrias e as diferenças de custo entre as tecnologias que poderiam ser aplicadas. As medidas de comando e controle também reduzem o rol de soluções que a indústria poderia implantar para lidar com suas questões ambientais ${ }^{351}$.

\footnotetext{
${ }^{348}$ Idem, p. 463-495.

${ }^{349}$ Idem, p. 465.

${ }^{350}$ Tradução livre do autor desta Dissertação. Do original: "regulation that requires specific action by a regulated entity, usually meeting stated technological standards of pollution or safety (often the best available technology)". Idem, ibidem.

${ }^{351}$ Tradução livre do autor desta Dissertação. Do original: "I am persuaded that the endless proliferation of command-and-control regulation is not, in general, a workable or appropriate long-run way of dealing with this problem. It is a relatively clumsy and costly approach. It essentially requires central regulators to determine how each of hundreds of thousands of industrial sources shall produce clean air and clean water and minimize the hazards associated with toxic wastes and their processing and disposal. This typically leads to rather uniform solutions in the regulations, regardless of the fact that some sources can control a
} 
Richard Stewart ainda destaca que, muitas vezes, o custo de seguir determinada regra é tão caro que acaba sendo mais barato combater administrativa e judicialmente as exigências, o que não traz ganhos para o meio ambiente e ocupa o tempo das autoridades públicas $^{352}$.

Os custos desproporcionais para a implantação da tecnologia definida pelos órgãos reguladores também pode trazer outro efeito adverso, qual seja, os atuais empreendedores ficam em desvantagem em relação aos antigos, cuja atividade já está em andamento. É o que ocorre, por exemplo, quando se exige que os carros novos tenham determinado tipo de tecnologia, mantendo intactos os carros mais velhos (muitas vezes, em maior número) $)^{353}$.

Resumidamente, ele defende as seguintes modalidades de incentivos econômicos ${ }^{354}$ :

lot more cheaply than others. It leads to information overload at the center from the processing of all this information. It tends to limit the solutions that the industry can adopt in dealing with environmental problems, typically specifying some sort of end-of-pipe control, or particular reduction in emissions rather than alternatives such as conservation or entire new technologies". Idem, p. 468.

352 Idem, ibidem.

${ }^{353}$ Idem, ibidem.

${ }^{354}$ Tradução livre do autor desta Dissertação. Do original: "Let me talk briefly about the basic areas where I see the use of economic incentives developing in the near term. The first type of economic incentive is the tradable permit approach. Under existing regulations, people are allowed to pollute up to a certain amount. In many cases you probably want to reduce the amount of pollution, or at least make sure it doesn't increase, so you impose a limit or a cap. But then allow trading, so that those firms that can find new ways to reduce pollution can sell their excess allowances to others. Pollution therefore has a price for everybody that is set by the market. Everybody has a continuing incentive not only to find the cheapest way under existing technology to reduce their own emissions, but also to develop new ways of doing so and turn environmental control into a profit center. (...) The prerequisites for using this tool are that, first, the allowances must describe some performance that is measurable - such as emissions of sulfur or discharges to a water body that can be measured and quantified. Second, you have to have a fairly large number of sources, or at least a significant variation in costs of control across the sources, because you are relying on a market in tradable permits. (...) Third, you have to deal with pollution problems that don't involve local 'hot spots' - that is, you have to deal with pollution that has a general effect. (...) A second type of incentive would be taxes. (...) Again, as with tradable permits, you need to monitor and enforce. One feature of taxes that is perhaps troubling, it that taxes might have to be constantly increased over time, in order to achieve the same effect, if you assume continuing economic growth. (...) With taxes, the level of control achieved is uncertain but the cost imposed is more predictable. Third, there are the deposit and return systems. The most familiar example is the system for cans and bottles used in some States. This technique could be used more widely and more powerfully - for example, to deal with hazardous waste. (...) We could have a deposit system where once you have generated a hazardous waste, you pay a large deposit to the Government. That deposit can be returned when either the original generator, or someone to whom it has been transferred, comes to the Government and proves by affirmative evidence that the waste has been properly disposed of and treated “. Idem, p. 471-472. 
- Tradable permit, pelo qual as pessoas são autorizadas a poluir até certo limite. Se conseguirem reduzir sua poluição, podem vender o direito excedente. Essas pessoas sempre tentarão reduzir ao máximo sua poluição, de forma a ganhar cada vez mais proventos com a venda dos direitos. Para que funcione, é necessário que haja parâmetros mensuráveis, tal como ocorre para volumes de gases e água. Em segundo lugar, é necessário que haja mercado para a comercialização dos direitos. Senão, não há quem compre. Em terceiro lugar, os danos ambientais decorrentes da poluição devem ter efeitos regionais ou globais. Caso contrário, não haverá mercado, pois os efeitos serão específicos de um determinado local.

- Taxes, pelo qual se cobram taxas dos poluidores. É uma forma bastante difundida. Para que seja minimamente eficaz, a taxa tem que ser proporcional ao porte do empreendimento e ser reajustada conforme o desenvolvimento da economia.

- Deposit and return, pelo qual se efetua o depósito de uma soma de dinheiro ao governo até se provar que determinada atitude foi tomada, quando, então, o dinheiro depositado é devolvido. Richard Stewart propõe o uso desse instrumento para resíduos perigosos. O governo só devolveria o dinheiro se fosse comprovado o correto gerenciamento, inclusive a destinação final, dos resíduos.

Por fim, como alternativa ao sistema de comando e controle, Richard Stewart propõe que seja estabelecido um preço para o direito de poluir. Se o empreendedor adotar técnicas mais limpas, esse preço deve ser reduzido gradualmente. Assim, torna-se interessante para ele ser mais sustentável. Esse sistema mesclaria instrumentos de comando e controle com incentivos ambientais. Além disso, os investimentos e os gastos econômicos deixariam de ir, exclusivamente, para o governo, passando a ser destinados, também, para prestadores de serviços pró-ambiente. Ampliam-se as modalidades de proteção, cada qual conforme o caso concreto e a atividade desenvolvida, e distancia-se da padronização ${ }^{355}$.

\footnotetext{
${ }^{355}$ Idem, ibidem.
} 
Na mesma obra, Donald Elliot menciona que só o empreendedor sabe qual é a forma mais eficaz de se reduzir a poluição. As autoridades públicas não têm material humano e informações suficientes para considerar todas as formas de atividade econômica, de forma que apenas os principais problemas são tratados ${ }^{356}$.

Se a questão fosse submetida às iniciativas do setor privado, todos os poluidores poderiam analisar suas próprias práticas, de forma que as proposições de redução de poluição abrangeriam pequenos e grandes poluidores.

O autor destaca que, politicamente, é mais fácil criar incentivos para a redução do que simplesmente criar restrições e limites. Ou seja, é provável que mais dirigentes sintam-se confortáveis para criar incentivos, enquanto poucos tomam a atitude de criar restrições ${ }^{357}$.

Por último, em sua contribuição à obra, David Hawkins destaca que é preciso pensar parâmetros objetivos e formas eficazes de monitorar os ganhos ambientais, a fim de se evitar fraudes e a quebra de confiança ${ }^{358}$.

\subsubsection{Experiência com serviços ecossistêmicos}

J. Ruhl, Steven Kraft e Christopher Lant tratam dos serviços ecossistêmicos e dos trade-offs de políticas ambientais ${ }^{359}$. Esses destacam que qualquer regime de gerenciamento de recursos naturais deve levar em conta as diferenças de ecossistemas, assim como as escalas de tempo e espaço ${ }^{360}$.

\footnotetext{
356 Tradução livre do autor desta Dissertação. Do original: "One of the things that appeals to me about incentive-based systems is that we are nearly at our capacity to deal with the management of a complex economic system through the information processing capacity of the government. Increasingly, as we look ahead, we are going to be talking about regulating large numbers of small sources because many of the larger sources have been regulated. One advantage of using a decentralized market system is that is has the ability to deal with the small source problem in a way that I'm not so sure the technique of bureaucracy is really capable of doing". Idem, p. 476.

${ }^{357}$ Idem, ibidem.

${ }^{358}$ Idem, p. 480.

${ }^{359}$ RUHL, J. B.; KRAFT, Steven E.; LANT, Christopher L. The law and policy of ecosystem services. Washington: Island Press, 2007.

${ }^{360}$ Tradução livre do autor desta Dissertação. Do original: "managing any particular ecosystem to yield a preferred service regime will have consequences for the flow of services from that ecosystem and from other. These feedback and feedforward effects will transpire at different spatial and temporal scales as
} 
Explicam que sempre haverá ganhadores e perdedores quando houver mudanças nas políticas ambientais e na legislação. É improvável que todos possam dividir igualmente os ganhos de um modelo, ou mesmo que todos possam experimentar tais ganhos $^{361}$. O importante é que o meio ambiente, como um todo, tenha ganhos e que seja alcançada a sustentabilidade.

Os autores enxergam como valioso o uso de um sistema de mercado de ativos ambientais, a exemplo do Clean Air Act norte-americano e o mercado de carbono do Protocolo de Quito à Convenção-Quadro das Nações Unidas sobre Mudança do Clima. Mas, consideram como desvantagem o fato de ter de existir autoridades reguladoras, bem como modelos confiáveis de mensuração de perdas e ganhos ${ }^{362}$.

Por fim, chamam atenção para o fato de que os serviços ecossistêmicos não têm recebido a devida atenção pelas autoridades públicas, ao contrário do que ocorre em outras temáticas, tal como espécies invasoras, mudanças climáticas, nanotecnologia e pobreza $^{363}$.

well. There are, in other words, ecological trade-offs to be faced within and between ecosystems as a consequence of decisions about how to manage a service regime at a particular place and time, and it is critical that any working model take these into account". Idem, p. 258.

361 J. Ruhl, Steven Kraft e Christopher Lant reportam: "It is highly unlikely, however, that everyone will share equally in the net gain to social welfare, or even that everyone will experience a gain. In particular, people who used ecosystem services as if they were free would find themselves paying for at least some of their use, either through prices charged in the market or though the cost of complying with regulatory prescriptions. Moreover, people who might have enjoyed opportunities were natural capital to be overdeveloped - say, the people who would be providing water quality services - may find fewer such opportunities. On the other hand, new and more profitable opportunities might open up for business and landowners and others as a result of more efficient decisions about natural capital and ecosystem services". Idem, ibidem.

${ }_{362}$ Idem, p. 278-279.

${ }^{363}$ Tradução do autor desta Dissertação. Do original: "Ecosystem services are complex ecologically, geographically and economically. So are invasive species, climate change, nanotechnology, poverty, and a host of other 'wicked' issues that challenge law and policy. The difference is that all those problems have found the attention of policymakers and have been addressed, albeit with varying success, in tangible ways through law and policy, whereas ecosystem services have been largely ignored". Idem, p. 293. 


\subsubsection{Experiência com a imputação de encargos}

Nick Hanley, Jason Shogren e Ben White reportam os efeitos econômicos e ambientais da imputação de encargos em determinados produtos e atividades conduzidas em países desenvolvidos, em especial nos Estados Unidos ${ }^{364}$.

Um primeiro caso é a imputação de encargos em atividades que emitem poluição no ar, na água, no solo, ou que gerem ruídos. Os encargos teriam por objetivo reduzir a quantidade ou a periculosidade das emissões forçando o poluidor a pagar, pelo menos, os custos dos impactos negativos que eles geram no meio ambiente ${ }^{365}$.

Para J. Ruhl, Steven Kraft e Christopher Lant, esse mecanismo fornece um incentivo aos empreendedores para desenvolver e adotar técnicas novas e melhores para reduzir a poluição, uma vez que isso significa a redução de encargos a serem pagos ao governo $^{366}$. O efeito é ainda mais eficaz nos casos em que os custos de redução de poluição são inferiores aos custos dos encargos: quanto maior a redução da poluição, maior a diferença dos custos.

Apontam que o mecanismo é utilizado em quase todos os países desenvolvidos, normalmente para a redução das emissões de água, resíduos e ruídos ${ }^{367}$.

Ensinam os autores que a imputação de encargos pode considerar uma atividade ou empreendimento isolado - como reportado nos parágrafos anteriores - ou uma coletividade de empreendimentos ${ }^{368}$.

Em um segundo caso, calcula-se a concentração da poluição em determinada região, onde haja vários empreendimentos, e define-se qual será o valor máximo de concentração de poluentes tanto para o local quanto para cada um dos empreendimentos. As atividades de fiscalização podem ser simplificadas se a medição ocorrer apenas no cenário global, sem necessidade de fiscalização em cada um dos empreendimentos - na

\footnotetext{
${ }^{364}$ HANLEY, Nick; SHOGREN, Jason; WHITE, Ben. Op. cit., p. 61.

${ }^{365}$ Idem, ibidem.

${ }^{366}$ Idem, ibidem.

${ }^{367}$ Idem, ibidem.

${ }^{368}$ Idem, p. 66.
} 
hipótese de irregularidade na concentração total, todos os empreendedores são penalizados conjuntamente ${ }^{369}$.

Por fim, ainda na estratégia da imputação de encargos, os referidos autores explicam que não somente as atividades ou empreendimentos podem sofrer taxação, mas também os produtos por eles manufaturados ${ }^{370}$.

\subsubsection{Experiência com subsídios}

Nick Hanley, Jason Shogren e Ben White definem os subsídios como forma de assistência financeira oferecida para o empreendedor pelo legislador ${ }^{371}$. Segundo esses autores, os subsídios podem ser utilizados como estímulo para encorajar o controle de poluição ou para mitigar os impactos econômicos de normas reguladoras, uma vez que auxiliam economicamente os empreendedores ${ }^{372}$.

Apontam que os subsídios costumam ocorrer na forma de doação, empréstimo ou compensação e ser lastreados por valores recolhidos a título de multas ambientais ${ }^{373}$.

Como exemplos de experiências na concessão de subsídios, Nick Hanley, Jason Shogren e Ben White citam (i) a França, que fornece empréstimos para a indústria controlar a poluição das águas; (ii) a Itália, que fornece subsídios para a reciclagem e recuperação de resíduos sólidos, favorecendo indústrias que se comprometem a alterar seu processo de fabricação; (iii) a Holanda, que criou um programa de assistência financeira que concede incentivos para as indústrias cumprirem as normas reguladoras, realizarem pesquisa tecnológica e implementarem equipamentos de controle de poluição; (iv) a Alemanha, que subsidia pequenos empreendedores no controle da poluição e na

\footnotetext{
${ }^{369}$ Idem, ibidem. Quanto ao tema, os autores registram: "The liability of each polluter depends on the aggregate emissions from the entire group of polluters, not just his own level of emissions, since these emissions are unobservable to the regulator. This creates a bubble of total ambient concentration that the entire group of producers must satisfy. If the total ambient concentration of a pollutant is found to exceed the standard, each polluter pays the full incremental social costs of the excessive ambient concentrations". ${ }^{370}$ Idem, p. 71.

${ }^{371}$ Tradução livre do autor desta Dissertação. Do original: "Subsidies are forms of financial assistance offered to a producer by regulators" (HANLEY, Nick; SHOGREN, Jason; WHITE, Ben. Op. cit., p. 72).

${ }^{372}$ Idem, ibidem.

${ }^{373}$ Tradução livre do autor desta Dissertação. Do original: "Subsidies normally take the form of grants, loans and tax allowances. Subsidies are widely applied in many countries, and are usually funded by environmental charges rather than from general tax revenues". Idem, ibidem.
} 
implementação de programas ambientais e (v) a Suécia, que oferece subsídios para a redução da utilização de pesticidas ${ }^{374}$.

Nos Estados Unidos, os referidos autores citam os subsídios concedidos para a construção de sistemas municipais de tratamento de água e para produtores rurais conduzirem atividades de conservação do solo ${ }^{375}$.

\subsection{Experiência da União Europeia}

Eckard Rehbinder relata que, tradicionalmente, a política ambiental da União Europeia baseou-se no uso de instrumentos de comando e controle, tais como proibições, exigência de permissões e padrões estabelecidos ${ }^{376}$.

Foi a partir de 1987, com a edição da Council Resolution of 19 October 1987 on the Continuation and Implementation of a European Community Policy, que a União Europeia passou a adotar instrumentos de estímulo ${ }^{377}$. Explica que, inicialmente, optou-se por criar taxas, estabelecendo um preço para a utilização de recurso naturais ${ }^{378}$.

Em 1990, o Conselho para o Meio Ambiente da União Europeia entendeu por bem reformular o conceito do princípio do poluidor pagador, para afirmar que o poluidor deve arcar não apenas com os custos de regularização de suas atividades, mas também internalizar os seus custos sociais. O Conselho entendeu que a instituição de taxas poderia proporcionar tal internalização de $\operatorname{custos}^{379}$.

\footnotetext{
${ }^{374}$ Idem, ibidem.

${ }^{375}$ Idem, p. 73.

${ }^{376}$ REHBINDER, Eckard. Op. cit., p. 58. Tradução do autor desta Dissertação. Do original: "Since the early 1970's, the European Community and the Member States have largely relied on traditional command and control instruments, such as prohibitions, permit requirements, standards, and planning obligations, to implement their environmental policies".

${ }^{377}$ Idem, ibidem.

${ }^{378}$ Idem, p. 59. O autor destaca: "The Community now focuses on negative incentives in the form of charges and taxes, thereby setting a price on the utilization of natural resources".

${ }^{379}$ Idem, p. 61. O autor registra: “(...) the Environmental Council took its first action in the field of economic and fiscal instruments: at its Dublin meeting in June 1990, the Council endorsed the proposition that Community environmental policy should diversify by including economic and fiscal instruments as implementation strategies. 15 The Council charged the Commission with a reappraisal of Community policy relating to the choice of instruments. The results of this reappraisal were submitted by the Commission to the Council in September 1990. The Commission communication called for a reformulation of the polluter pays principle, interpreting article 130R(2) to mean that the polluter should not only bear the cost of
} 
Adicionalmente, foi aprovada a intenção de suplementar os mecanismos de comando e controle com instrumentos econômicos e fiscais ${ }^{380}$. Inicialmente, aplicou-se a nova estratégia para a regulamentação da emissão de gases e do sistema de transporte ${ }^{381}$.

Segundo Eckard Rehbinder, no campo da emissão de gases, a utilização de instrumentos econômicos - neste caso, a instituição de taxas - promoveu a eficiência energética, além de favorecer fontes que não estão associadas com emissões de gás carbônico, isto é, fontes renováveis, tal como a energia nuclear ${ }^{382}$.

No setor de transportes, a utilização de instrumentos econômicos encontra diferenças significativas entres os países da União Europeia. A imposição de taxas e encargos pode recair sobre o combustível, sobre o veículo ou ainda sobre a distância percorrida em determinada via. Cada estratégia traz um impacto fiscal e ambiental diferente $^{383}$.

\footnotetext{
regulation but, also, should fully internalize the social costs caused by its polluting activities. The Commission viewed charges and taxes as the means by which to achieve this internalization".

${ }^{380}$ Idem, ibidem. O autor aponta: "The Council generally approved the Commission's reformulation of the polluter pays principle and the idea of at least supplementing traditional command and control regulation with economic and fiscal instruments".

${ }^{381}$ Idem, ibidem.

${ }^{382}$ Idem, p. 69. Quanto ao tema, o autor aponta: "Within the framework of the Community's global climate policy, the marked differences amongst the Member States regarding the structure of their energy sources and their technical innovative capacity may yield severe distributional impacts. The combined energy/CO2 tax not only promotes energy efficiency, but also favors energy sources that are not (or are less) associated with $\mathrm{CO} 2$ emissions, i.e., renewable energy sources and, of particular consequence in the EC, nuclear energy".

${ }^{383}$ Idem, p. 70. Quanto ao tema, o autor aponta: "Comparable problems of distortion of competition among different Member States arise in the field of transportation policy. The Member States have quite different systems for imputing to carriers the infrastructure and environmental costs of transportation. 49 Some states have two component systems, consisting of motor vehicle taxes and excise taxes on fuel. Other Member States have cost-imputation systems that consist of three components, adding road user charges. Since all of these systems contain both taxes that are levied only on national carriers and taxes that are imposed on all users (according to the principle of territoriality), and, in addition, because the structures and rates of the taxes differ from country to country, the competitive conditions that result vary significantly amongst the Member States (...). Each of the components of Member State transportation tax systems discussed above impacts domestic and Community fiscal and environmental policy differently".
} 
Eckard Rehbinder reporta que, na Alemanha, os instrumentos econômicos já eram utilizados na década de 1970, embora em pequena escala. Estavam restritos à imposição de taxas para a emissão de efluentes e ao mercado de permissões de emissão de poluentes ${ }^{384}$.

Segundo ele, a imposição de taxas para a emissão de efluentes encontrava dois propósitos: (i) promover o cumprimento com os padrões federais de efluentes e (ii) promover reduções voluntárias adicionais aos padrões estabelecidos ${ }^{385}$.

Reporta que havia dificuldades técnicas para a redução de alguns efluentes, motivo pelo qual sua redução não atingiu patamares imaginados. Além disso, houve a necessidade de fortalecer o sistema de monitoramento das emissões, o que, ironicamente, representa a aplicação de um método tradicional do sistema de comando e controle ${ }^{386}$.

Em 1991, uma nova iniciativa do governo alemão determinou que os produtores de embalagens seriam os exclusivos responsáveis pelos custos do ciclo de vida de seus produtos. Stephanie Goldfine explica que a medida classificou-se como um instrumento econômico focado em internalizar os custos da destinação final de resíduos de embalagens no país ${ }^{387}$.

\footnotetext{
${ }^{384}$ Idem, p. 72.

${ }^{385}$ Idem, p. 73.

${ }^{386}$ Idem, ibidem. Quanto ao ponto, o autor esclarece: "The German effluent charge has had the ironic effect of greatly improving the implementation and enforcement of traditional command and control regulation. One reason for this effect was that all permits had to be reviewed and new parameters added in order to levy the charge. Furthermore, implementation of the Act required improvement of the monitoring system. These extrafunctional effects largely supplanted the intended incentive effect - or at least obscured it".

${ }^{387}$ GOLDFINE, Stephanie. Op. cit., p. 309. Quanto ao tema, a autora reporta: "In 1991, Germany adopted a controversial regulation that requires manufacturers to be responsible for the life-cycle cost of packaging. Utilizing market based economic incentives, Germany embarked upon the most comprehensive attempt to date to make solid waste producers internalize the costs of waste disposal".
} 
Segundo Stephanie Goldfine, a norma representa uma tentativa de convencer os empreendedores de que é deles a responsabilidade pelos custos dos resíduos que produzem $^{388}$. Cria-se a obrigação para os empreendedores de recolherem os materiais usados para, então, proceder à reciclagem, reúso ou disposição final ${ }^{389}$.

A utilização de instrumento econômico para o controle de resíduos de embalagens na Alemanha trouxe resultados positivos, mas alguns objetivos não foram alcançados. Stephanie Goldfine explica que a consciência ambiental dos consumidores, comerciantes e produtores fortaleceu-se, mas não houve significativa redução do volume de resíduos gerados ou desenvolvimento de infraestrutura para a reciclagem desse material $^{390}$.

\footnotetext{
${ }^{388}$ Idem, p. 320. Tradução livre do autor desta Dissertação. Do original: "The German packaging ordinance represents a comprehensive attempt to make producers accept responsibility for the cost of the waste they produce".

${ }^{389}$ Idem, ibidem.

${ }^{390}$ Idem, p. 333. Quanto ao tema, a autora anota: "The German experience with the packaging ordinance may be characterized in two distinct manners. On the one hand, all segments of German society, specifically consumers, retailers and manufacturers, have begun to modify their behavior with regard to packaging waste and to develop along a more environmentally conscious path. On the other hand, the system established by the ordinance to institute the desired shift has been plagued by economic difficulties and has not resulted in either a substantial reduction in the volume of packaging or in the creation of sufficient capacity to deal with the volume of material for recycling".
} 


\section{CONCLUSÕES E PROPOSTAS}

Este Capítulo destina-se a fazer um encerramento de todo o trabalho e apresentar algumas propostas voltadas aos aplicadores do Direito, de forma a contribuir com o fortalecimento e a criação de incentivos ambientais no Brasil.

Embora as conclusões aqui apresentadas possam divergir do entendimento de parte da doutrina, espera-se que as reflexões apontadas, todas baseadas em literatura especializada e na experiência do pesquisador, autor desta Dissertação, possam contribuir com o aperfeiçoamento dos instrumentos utilizados para a proteção do meio ambiente.

É vital o papel desenvolvido pelo Direito na prevenção de danos e na proteção do meio ambiente, principalmente diante do poder da tecnologia e do desenvolvimento de máquinas e empreendimentos de grandes magnitudes. As normas, resultado da positivação do Direito, são a principal ferramenta para que o Estado desenvolva seu papel de estimulador de boas práticas ou de punidor de infrações. Elas refletem um dever-ser da conduta, um conjunto de proibições, obrigações ou permissões, por meio do qual os homens criam entre si relações de subordinação, coordenação, organizam seu comportamento coletivamente, interpretam suas próprias prescrições, delimitam o exercício do poder, estimulam o rumo de sua sociedade e economia etc ${ }^{391}$.

Na seara ambiental, é necessária a positivação de obrigações e estímulos para a garantia de um meio ambiente equilibrado.

Referida positivação pode ter por resultado normas de natureza protetivorepressiva ou promocional, conforme exposto no Capítulo 1. No primeiro caso, existem três modos típicos de impedir uma ação não desejada: torná-la impossível, torná-la difícil ou torná-la desvantajosa. Por outro lado, o ordenamento promocional busca atingir os mesmos fins por três operações contrárias, isto é, buscando tornar a ação desejada necessária, fácil ou vantajosa ${ }^{392}$.

\footnotetext{
${ }^{391}$ Cf. item 1.2.

${ }^{392}$ Cf. item 1.2.
} 
Tais operações podem agir em comportamentos já realizados ou em comportamentos que virão ou estão se desenvolvendo. Enquanto medida prévia, estabelecem uma ameaça, a título de desencorajamento, ou uma promessa, a título de encorajamento. Por outro lado, quando aplicadas em condutas já realizadas, encaixam-se como uma reação do Estado que pode ser favorável, quando o comportamento é desejado, ou desfavorável, quando o comportamento é indesejado.

Conforme exposto nos Capítulos 1 e 3, o modelo repressor não tem atingido os resultados que a sociedade espera, além de representar um ônus excessivo aos cofres públicos $^{393}$. Norberto Bobbio ensina que o amadurecimento da sociedade fez com que o Estado deixasse sua função garantista e passasse a um papel dirigista, promovendo a realização de atos socialmente desejáveis ${ }^{394}$.

Isso significa a substituição do sistema de comando e controle por um sistema composto por incentivos positivos, tais como instrumentos econômicos, redução de encargos tributários, pagamento por serviços ambientais, instrumentos de mercado etc ${ }^{395}$. O Direito é capaz de direcionar a sociedade pelo uso de incentivos, de forma a promover a realização de atos socialmente desejáveis.

As sanções positivas ganham espaço no espírito dirigista do Estado contemporâneo, quando o Direito não mais se limita à sua função de tutela, tendendo a estimular atos inovadores. Com isso, paralelamente ao emprego quase exclusivo das sanções negativas, passam-se a empregar sanções positivas, que darão estímulo e propulsão a atos considerados benéficos à sociedade.

Na esfera ambiental, negar essa evolução é negar o reconhecimento e o estímulo das pessoas que respeitam a legislação, contribuem para a qualidade de vida da sociedade e não cometem atitudes que causem prejuízo ao meio ambiente. É fechar os olhos para o fato de que incentivar a conduta positiva ao meio ambiente é incentivar, indiretamente, a prevenção de danos ambientais.

\footnotetext{
${ }^{393}$ Cf. itens 1.3 e 3.1 .

${ }^{394}$ BOBBIO, Norberto. Op. cit., p. XII. Cf. item 1.3.

${ }^{395}$ Cf. item 4.2 .
} 
É preciso considerar que o Estado repressor, pelo sistema de comando e controle, nada faz para aquele que trabalha muito abaixo dos padrões de poluição, de forma que este poderá preferir chegar até próximo dos níveis permitidos, caso isso represente uma redução de custo operacional. É preciso existir vantagem para aquele que está abaixo dos níveis estabelecidos.

No Direito Ambiental brasileiro, ainda são dominantes as normas de caráter repressor. A lei que cria o Sistema Nacional do Meio Ambiente (Lei no 6.938/1981 ${ }^{396}$ ), estabelecendo os princípios, objetivos e a estrutura institucional desse sistema, prevê instrumentos que, em sua maioria, têm caráter de comando e controle, tais como: (i) padrões de qualidade ambiental; (ii) zoneamento ambiental; (iii) avaliação de impactos ambientais; (iv) licenciamento ambiental; (v) penalidades disciplinares ou compensatórias; (vi) criação de espaços territoriais especialmente protegidos e (vii) relatório de qualidade do meio ambiente ${ }^{397}$.

De toda forma, tal como demonstrado no Capítulo 5, é cada vez maior o número de normas de caráter estimulador, em que são previstos diferentes modelos de incentivos, a exemplo das seguintes: (i) a Lei da Política Nacional do Meio Ambiente (Lei ${ }^{\circ}$ $6.938 / 1981^{398}$ ), que previu como princípio a concessão de incentivos ao estudo e à pesquisa de tecnologias orientadas para o uso racional e a proteção dos recursos ambientais (artigo $2^{\circ}$, inciso VI); (ii) a Lei $\mathrm{n}^{\mathrm{o}} 11.428 / 2006^{399}$, que estabelece a concessão de incentivos econômicos para estimular a proteção e o uso sustentável do Bioma Mata Atlântica (artigo 33) e incentivos creditícios para o proprietário ou posseiro que tenha vegetação primária ou secundária em estágios avançado e médio de regeneração do Bioma Mata Atlântica (artigo 41, inciso I); (iii) a Lei $\mathrm{n}^{\circ} 12.187 / 2009^{400}$, que instituiu a Política Nacional sobre Mudança do Clima, a qual prevê como diretriz a utilização de instrumentos financeiros e econômicos para promover ações de mitigação e adaptação à mudança do clima (artigo 6 ${ }^{\circ}$, VI); (iv) a Política Nacional de Resíduos Sólidos, instituída

\footnotetext{
396 BRASIL. Lei $\mathrm{n}^{\mathrm{o}} 6.938$ de 31 de agosto de 1981. Disponível em: $<$ http://www.planalto.gov.br/ccivil_03/leis/16938.htm>. Acesso em: 31 março 2014.

${ }^{397}$ Cf. Capítulo 3.

398 BRASIL. Lei $\mathrm{n}^{\mathrm{o}} 6.938$ de 31 de agosto de 1981. Disponível em: $<$ http://www.planalto.gov.br/ccivil_03/leis/16938.htm>. Acesso em: 31 março 2014.

399 BRASIL. Lei $\mathrm{n}^{\mathrm{o}} 11 . \overline{4} 28$, de 22 de dezembro de 2006 . Disponível em: <http://www.planalto.gov.br/ccivil_03/_ato2004-2006/2006/lei/111428.htm>. Acesso em: 31 março 2014.

400 BRASIL. Lei $\mathrm{n}^{\mathrm{o}} 12 . \overline{1} 87$, de 29 de dezembro de 2009. Disponível em: <http://www.planalto.gov.br/ccivil_03/_ato2007-2010/2009/lei/112187.htm>. Acesso em: 31 março 2014.
} 
pela Lei $\mathrm{n}^{\mathrm{o}} 12.305 / 2010^{401}$, com inúmeros dispositivos em que incentivos são criados para possibilitar o gerenciamento dos resíduos sólidos em território brasileiro (artigos $7^{\circ}$ e $8^{\circ}$ ); (v) a Lei no 12.512/2011 ${ }^{402}$, que instituiu o Programa de Apoio à Conservação Ambiental e autoriza que a União transfira recursos financeiros e disponibilize serviços de assistência técnica a famílias em situação de extrema pobreza que desenvolvam atividades de conservação de recursos naturais no meio rural (artigo $2^{\circ}$ ); (vi) a Lei $n^{\circ}$ $12.651 / 2012^{403}$, que instituiu o Novo Código Florestal Brasileiro, a qual permite ao governo federal instituir programa de apoio e incentivo à conservação do meio ambiente, bem como para adoção de tecnologias e boas práticas que conciliem a produtividade agropecuária e florestal, com redução dos impactos ambientais, como forma de promoção do desenvolvimento ecologicamente sustentável (artigo 41) e (vii) a Lei $\mathrm{n}^{\mathrm{o}}$ $12.854 / 2013^{404}$, que fomenta e incentiva ações que promovam a recuperação florestal e a implantação de sistemas agroflorestais em áreas rurais desapropriadas pelo Poder Público e em áreas degradadas em posse de agricultores familiares assentados, de quilombolas e de indígenas (artigo $\left.1^{\mathrm{o}}\right)^{405}$.

Tais normas têm abrangência federal. No âmbito estadual, os Estados de São Paulo, Pará e Minas Gerais também contam com importante legislação com caráter estimulador de práticas favoráveis ao meio ambiente ${ }^{406}$. Em especial, citamos a Lei Estadual $\mathrm{n}^{\mathrm{o}} 13.798 / 2009^{407}$, do Estado de São Paulo, que criou o Programa de Remanescentes Florestais, no qual se permite o pagamento por serviços florestais ambientais aos proprietários rurais conservacionistas, bem como incentivos econômicos a políticas voluntárias de redução de desmatamento e proteção ambiental ${ }^{408}$.

\footnotetext{
401 BRASIL. Lei $\mathrm{n}^{\mathrm{o}}$ 12.305, de 2 de agosto de 2010. Disponível em: <http://www.planalto.gov.br/ccivil_03/_ato2007-2010/2010/lei/112305.htm>. Acesso em: 31 março 2014. 402 BRASIL. Lei $\mathrm{n}^{\mathrm{o}} 12.512$, de 14 de outubro de 2011. Disponível em: $<$ http://www.planalto.gov.br/ccivil_03/_ato2011-2014/2011/Lei/L12512.htm>. Acesso em: 31 março 2014. 403 BRASIL. Lei $\mathrm{n}^{\mathrm{o}} 1 \overline{2} .65 \overline{1}$, de 25 de maio de 2012. Disponível em: $<$ http://www.planalto.gov.br/ccivil_03/_ato2011-2014/2012/lei/112651.htm>. Acesso em 31 março 2014. 404 BRASIL. Lei $\mathrm{n}^{\mathrm{o}} 1 \overline{1}^{-} .85 \overline{4}$, de 26 de agosto de 2013. Disponível em: $<$ http://www.planalto.gov.br/ccivil_03/_Ato2011-2014/2013/Lei/L12854.htm>. Acesso em: 31 março 2014.

${ }^{405}$ Cf. item 5.1 .

${ }^{406} \mathrm{Cf}$. item 5.1.

407 SÃO PAULO. Lei Estadual $\mathrm{n}^{\circ}$ 13.798, de 9 de novembro de 2009. Disponível em: $<$ http://www.al.sp.gov.br/norma/?id=158351>. Acesso em: 31 março 2014.

${ }^{408} \mathrm{Cf}$. item 5.3 .
} 
Por fim, em âmbito municipal, algumas prefeituras estabeleceram isenções ou reduções na cobrança do IPTU para os proprietários de imóveis que trouxessem ganhos ambientais à cidade. A iniciativa, popularmente denominada "IPTU Verde" ou "IPTU Ecológico", conta, pelo menos, com os seguintes municípios: Araraquara/SP (Lei Municipal n $n^{\text {0 7.152/2009 }}{ }^{409}$ ); Cabo Frio/RJ (Lei Municipal no 2.443/2012 $2^{410}$ ); Curitiba/PR (Lei Municipal no 9.806/2000 ${ }^{411}$ ); Guaíra/SP (Lei Municipal $n^{\circ}$ 2.491/2011 ${ }^{412}$ ); São Vicente/SP (Lei Complementar Municipal no 634/2010413); São Bernardo do Campo/SP (Lei Municipal $\mathrm{n}^{\mathrm{o}}$ 6.091/2010 $0^{414}$ ); Sorocaba/SP (Lei Municipal $\mathrm{n}^{\mathrm{o}}$ 9.571/2011 ${ }^{415}$ ); Guarulhos/SP (Lei Municipal $n^{\circ} 6.793 / 2010^{416}$ ) e Vila Velha/ES (Lei Municipal $n^{\circ}$ $\left.4.864 / 2009^{417}\right)^{418}$.

Sob o viés da responsabilidade civil, o papel de tutela desenvolvido pelo Direito engloba funções ressarcitória, dissuasória e preventiva. Todavia, a evolução do conceito de responsabilidade civil, acompanhada pela mudança social e econômica, adicionou uma função preventiva, de caráter antecipatório, expandida em razão dos riscos crescentes.

\footnotetext{
409 ARARAQUARA. Lei Municipal $\mathrm{n}^{\circ}$ 7.152, de 8 de dezembro de 2009. Disponível em: $<$ https://www.leismunicipais.com.br/a/sp/a/araraquara/lei-ordinaria/2009/715/7152/lei-ordinaria-n-71522009-concede-isencao-de-imposto-predial-e-territorial-urbano-para-propriedades-que-conservarem-areaarborizada-iptu-verde-2009-12-08.html>. Acesso em: 31 março 2014.

410 CABO FRIO. Lei Municipal $\mathrm{n}^{\mathrm{o}}$ 2.443, de 19 de junho de 2012. Disponível em: $<$ http://www.cmcabofrio.rj.gov.br>. Acesso em: 31 março 2014.

411 CURITIBA. Lei Municipal $n^{\circ}$ 9.806, de 29 de março de 2010 de 2000. Disponível em: $<$ https://www.leismunicipais.com.br/a/pr/c/curitiba/lei-ordinaria/2000/980/9806/lei-ordinaria-n-9806-2000institui-o-codigo-florestal-do-municipio-de-curitiba-revoga-as-leis-n-8353-93-e-8436-94-e-da-outrasprovidencias.html>. Acesso em: 31 março 2014.

${ }^{412}$ GUAÍRA. Lei Municipal $\mathrm{n}^{\mathrm{o}}$ 2.491, de 2 de março de 2011. Disponível em: <http://www.camaraguaira.sp.gov.br/camver/LEIMUN/2011/02491.pdf>. Acesso em: 31 março 2014.

413 SÃO VICENTE. Lei Complementar Municipal no 634, de 5 de novembro de 2010. Disponível em: $<$ http://www.saovicente.sp.gov.br/ambiental/pdf_12/04/634.pdf $>$. Acesso em: 31 março 2014.

${ }^{414}$ SÃO BERNARDO DO CAMPO. Lei Municipal $\mathrm{n}^{\circ}$ 6.091, de 9 de dezembro de 2010. Disponível em: $<$ https://www.leismunicipais.com.br/a2/sp/s/sao-bernardo-do-campo/lei-ordinaria/2010/609/6091/leiordinaria-n-6091-2010-disciplina-a-concessao-de-beneficio-fiscal-aos-imoveis-com-area-de-coberturavegetal-ou-destinados-a-producao-hortifrutigranjeira-e-da-outras-providencias.html?wordkeytxt=6091>. Acesso em: 31 março 2014.

415 SOROCABA. Lei Municipal $\mathrm{n}^{\mathrm{o}}$ 9.571, de 16 de maio de 2011. Disponível em: $<$ http://www.camarasorocaba.sp.gov.br/sitecamara/proposituras/verpropositura $>$. Acesso em: 31 março 2014.

416 GUARULHOS. Lei Municipal $\mathrm{n}^{\mathrm{o}}$ 6.793, de 28 de dezembro de 2010. Disponível em: $<$ http://leis.guarulhos.sp.gov.br/06_prefeitura/leis/leis_download/06793lei.pdf>. Acesso em: 31 março 2014.

417 VILA VELHA. Lei Municipal $\mathrm{n}^{\mathrm{o}}$ 4.864, de 29 de dezembro de 2009. Disponível em: $<$ http://www.legislacaoonline.com.br/vilavelha/images/leis/html/L48642009.html $>$. Acesso em: 31 março 2014.

${ }^{418}$ Cf. item 5.1.
} 
Essa função preventiva deverá englobar atitudes de prevenção e de precaução, ambas convertidas em princípios de Direito ${ }^{419}$. Portanto, responsabilidade civil não se resume ao ressarcimento de danos (apesar de ainda ser essa sua principal função); é, também, prevenção e precaução de eventos danosos.

No Direito Ambiental, as regras de responsabilidade têm regime próprio e englobam três esferas: civil, administrativa e criminal. Encontram lastro nas Leis $\mathrm{n}^{\mathrm{o}}$ 6.938/1981 ${ }^{420}$ e $n^{\circ} 9.605 / 1998^{421}$, no Decreto $n^{\circ} 6.514 / 2008^{422}$ e na Constituição Federal de $1988^{423-424}$.

O sistema de responsabilidade ambiental está voltado para punir condutas indesejáveis, sem espaço para a previsão de sanções positivas às condutas que possam ser saudáveis ao meio ambiente, mesmo que a imposição da maior parte das penas não traga benefícios à sociedade e, muito menos, para o meio ambiente, a não ser que sejam, necessariamente, acompanhados da reparação efetiva do dano ambiental. Além de trazer poucos benefícios à sociedade e ao meio ambiente, as penas tradicionais do sistema de responsabilidade ambiental não são suficientes para inibir a prática de novos delitos ${ }^{425}$.

Esse regime repressor, pautado em instrumentos de comando e controle, traz gastos excessivos ao Estado, principalmente em um País de dimensões continentais como o Brasil, sujeitando o sistema como um todo à ineficiência. Apenas a título de ilustração, tal como demonstrado no Capítulo 3, no ano de 2012, os cofres públicos arcaram com aproximadamente 30 bilhões de reais para Poder Judiciário ${ }^{426}$ e 1,1 bilhão de reais para o

\footnotetext{
${ }^{419}$ Cf. item 2.1 .

420 BRASIL. Lei $\mathrm{n}^{\mathrm{o}}$ 6.938, de 31 de agosto de 1981. Disponível em: $<$ http://www.planalto.gov.br/ccivil_03/leis/16938.htm>. Acesso em: 31 março 2014.

421 BRASIL. Lei $\mathrm{n}^{\circ} 9 . \overline{605}$, de 12 de fevereiro de 1998. Disponível em: <http://www.planalto.gov.br/ccivil_03/leis/19605.htm>. Acesso em: 31 março 2014.

${ }_{422}$ BRASIL. Decreto $\mathrm{n}^{\mathrm{o}}-6.514$, de 22 de julho de 2008. Disponível em: <http://www.planalto.gov.br/ccivil_03/_ato2007-2010/2008/decreto/D6514.htm>. Acesso em: 31 março 2014.

423 BRASIL. Constituição Federal (1988). Disponível em: $<$ http://www.planalto.gov.br/ccivil_03/constituicao/constituicao.htm>. Acesso em: 31 março 2014.

${ }^{424}$ Cf. item 3.1.

${ }^{425} \mathrm{Cf}$. item 3.1.

${ }^{426}$ Informações constantes da "Execução Orçamentária dos Órgãos do Poder Judiciário Integrantes do Orçamento Geral da União (OGU) - Exercício 2012". Disponível em: <www.cnj.jus.br>. Acesso em: 31 março 2014.
} 
IBAMA $^{427}$. Previu-se, no orçamento da União, gastos na ordem de 2,3 bilhões de reais com o Ministério Público Federal ${ }^{428}$.

No Estado de São Paulo, também para o ano de 2012, a CETESB previu em seu orçamento gastos no valor de R $\$ 348.846 .951,00^{429}$. Para o mesmo ano, o Ministério Público do Estado de São Paulo previu gastos de R\$1.532.278.218,00 ${ }^{430}$. Em vista de tais dados, é possível notar quão significativos são os gastos dos principais órgãos investigadores, fiscalizadores e sancionadores do sistema jurídico brasileiro.

Imprescindível, portanto, que sejam utilizadas e fortalecidas as modalidades de incentivos já previstas no ordenamento jurídico, bem como sejam criadas novas modalidades para que a proteção do meio ambiente seja eficaz, o que garantirá a qualidade de vida das presentes e futuras gerações.

Importante notar que os incentivos ambientais podem assumir diferentes formas e naturezas, tais como norma jurídica, procedimento, prestação de serviço, produto etc ${ }^{431}$. Podem ser divididos em prévios e posteriores em relação à conduta desejada, divisão essa que facilita a sua compreensão e utilização no campo do Direito Ambiental.

São exemplos de incentivos prévios: (i) redução do encargo tributário; (ii) redução dos procedimentos burocráticos de regularização da propriedade; (iii) concessão de facilidades na obtenção de empréstimos financeiros; (iv) fornecimento de serviços públicos e (v) disponibilização de tecnologia.

\footnotetext{
427 Informações constantes da "Execução Orçamentária" do IBAMA. Disponível em: <www.ibama.gov.br>. Acesso em: 31 março 2014.

${ }^{428}$ Informações constantes do documento "Orçamentos da União - Exercício Financeiro 2012" do Ministério do Planejamento, Orçamento e Gestão do Governo Federal. Disponível em: $<$ http://www.planejamento.gov.br/secretarias/upload/Arquivos/sof/ploa2012/110831_ploa2012_vol3.pdf>. Acesso em: 31 março 2014.

429 Informações constantes do "Orçamento do Estado 2012", da Secretaria de Planejamento e Desenvolvimento Regional do Governo do Estado de São Paulo. Disponível em: $<$ http://www.planejamento.sp.gov.br/noti_anexo/files/planejamento_orcamento/orcamentos/2011/Lei_1467 5 de_28_12_11.pdf>. Acesso em: 31 março 2014.

430 Informações constantes do "Orçamento do Estado 2012", da Secretaria de Planejamento e Desenvolvimento Regional do Governo do Estado de São Paulo. Disponível em: $<$ http://www.planejamento.sp.gov.br/noti_anexo/files/planejamento_orcamento/orcamentos/2011/Lei_1467 5 de_28_12_11.pdf > . Acesso em: 31 março 2014.

${ }^{4 \overline{31}} \mathrm{C} \overline{\mathrm{f}}$. item 4.2 .
} 
Como incentivos posteriores à conduta desejada, podem ser citados: (i) o pagamento por serviços ambientais; (ii) criação de lista ou ranking das pessoas com boas práticas ambientais e (iii) criação de instrumentos de mercado.

Essas modalidades de incentivos são apenas exemplos e estão focadas na realidade brasileira, de forma que outros instrumentos podem ser utilizados, tais como subsídios, instituição de taxas e encargos etc. A exemplificação de tais modalidades não busca exaurir todas as formas de incentivos ambientais que possam existir ou serem implantadas no Brasil, servindo apenas para ilustrar alguns exemplos existentes no momento da preparação do presente trabalho.

Como demonstrado no Capítulo 4, os incentivos podem envolver, ou não, a transferência direta de recursos financeiros.

Importante registrar que a concessão de incentivos ambientais encontra defensores e críticos na doutrina nacional e internacional. Os argumentos não se restringem ao Direito e visitam a Economia, a Filosofia, a Ética e a Sociologia, dentre outras Ciências, demonstrando diferentes visões sobre a interação entre o homem e os meios bióticos e abióticos ${ }^{432}$.

Quanto ao ponto, independentemente da corrente que se adote, é preciso que a sociedade reconheça a importância econômica, social e ambiental dos grupos que protegem o meio ambiente. É nesse contexto que se insere a recompensa, o incentivo ambiental. Isso, como demonstrado, dá mais efetividade às leis ambientais ${ }^{433}$.

Considerando a inexistência de jurisprudência assentada sobre a matéria, é importante, também, que os julgadores estejam cientes do importante papel desenvolvido pelos incentivos ambientais na proteção do meio ambiente.

\footnotetext{
${ }^{432}$ Cf. itens 5.4. e 5.5 .

${ }^{433}$ Cf. itens $1.2,1.3$ e 1.4 .
} 
Vale notar que tanto a sociedade quanto os aplicadores do Direito devem considerar as experiências e resultados de políticas adotadas em outros países. Como demonstrado no Capítulo 6, a Costa Rica, os Estados Unidos e alguns países da União Europeia desenvolveram instrumentos de incentivo voltados para a proteção do meio ambiente em diferentes situações, o que trouxe resultados satisfatórios e, algumas vezes, insatisfatórios.

De qualquer forma, servem como fonte de dados para que as políticas a serem adotadas no Brasil alcancem os melhores resultados possíveis.

Da mesma maneira, os tratados internacionais atualmente em vigor demonstram a tendência da comunidade internacional no trato das questões ambientais. Acordos como a Convenção sobre Diversidade Biológica e a Convenção das Nações Unidas sobre Mudança do Clima utilizam, nitidamente, instrumentos de estímulo a práticas favoráveis ao meio ambiente ${ }^{434}$.

Frente ao exposto, ressaltando o fato de que o presente trabalho tem viés jurídico e, inevitavelmente, encontra limitações e enfrentará posicionamentos contrários, seguem algumas propostas para o aprofundamento do assunto e o aperfeiçoamento das ideias relacionadas à proteção do meio ambiente.

Em primeiro lugar, é necessária uma abordagem de cunho econômico quanto aos instrumentos utilizados pelo Direito Ambiental. Essa abordagem pode estar voltada às modalidades dos incentivos aqui apontados ou mesmo aos diversos instrumentos utilizados pelo Estado no gerenciamento do meio ambiente.

Tal como demonstrado no Capítulo 5, é, também, imprescindível que análises de custo-benefício sejam realizadas para cada política ambiental individual lançada pelas autoridades públicas, de forma a garantir o aumento do bem estar dos indivíduos que compõem a sociedade ${ }^{435}$.

\footnotetext{
${ }^{434} \mathrm{Cf}$. itens 6.2 e 6.3 .

${ }^{435} \mathrm{Cf}$. item 5.4 e 5.6 .
} 
É importante que seja feita a contabilidade dos efeitos quantitativos e qualitativos de uma regulação, na qual as razões da iniciativa devem ser explicadas, principalmente quando os custos excederem os benefícios. Por certo, devem ser considerados tantos os valores econômicos como os não-econômicos nessa contabilidade.

Convém destacar, uma vez mais, que não se propõe extinguir a função punitiva do Estado, nem tampouco criar uma espécie de salário a todos aqueles que cumprem suas obrigações legais. Defende-se, isso sim, que o Direito Ambiental esteja focado na concessão de incentivos a práticas ambientais, para que esteja assegurada a proteção ao meio ambiente. 


\section{REFERÊNCIAS BIBLIOGRÁFICAS}

ACCIOLY, Hildebrando; NASCIMENTO e SILVA, Geraldo Eulálio do; CASELLA, Paulo Borba. Manual de direito internacional público. 16. ed. São Paulo: Saraiva, 2008.

ACKERMAN, Bruce. Reforming Environmental Law: The Democratic Case for Market Incentives. Faculty Scholarship Series. Paper 141, 1998. Disponível em: $<$ http://digitalcommons.law.yale.edu/cgi/viewcontent.cgi?article=1140\&context=fss_pap er>. Acesso em: 31 março 2014.

ALEVIZATOS, Dorothy; C. PERCIVAL, Robert V. (Editors). Law and the environment: a multidisciplinary reader. Philadelphia: Temple University Press, 1997.

AMARAL, Carlos; MAY, Peter H.; MILLIKAN, Brent; ASCHER, Petra (Orgs.). Instrumentos econômicos para o desenvolvimento sustentável da Amazônia brasileira. Brasília: Ministério do Meio Ambiente, 2005. Disponível em: $<$ http://www.mma.gov.br/estruturas/168/_publicacao/168_publicacao30012009115059.p df>. Acesso em: 31 março 2014.

ANDRADE, André Gustavo Corrêa de. Indenização punitiva. Disponível em: $<$ http://www.tjrj.jus.br/c/document_library/get_file?uuid=dd10e43d-25e9-478f-a346ec511dd4188a\&groupId=10136>. Acesso em: 31 março 2014.

ANDRADE FILHO, Edmar Oliveira. Infrações e sanções tributárias. São Paulo: Dialética, 2003.

ARARAQUARA. Lei Municipal no 7.152, de 8 de dezembro de 2009. Disponível em: $<$ https://www.leismunicipais.com.br/a/sp/a/araraquara/lei-ordinaria/2009/715/7152/leiordinaria-n-7152-2009-concede-isencao-de-imposto-predial-e-territorial-urbano-parapropriedades-que-conservarem-area-arborizada-iptu-verde-2009-12-08.html>. Acesso em: 31 março 2014. 
ASCHER, Petra; MILlIKAN, Brent; AMARAL, Carlos; MAY, Peter H. (Orgs.). Instrumentos econômicos para o desenvolvimento sustentável da Amazônia brasileira. Brasília: Ministério do Meio Ambiente, 2005. Disponível em: $<$ http://www.mma.gov.br/estruturas/168/_publicacao/168_publicacao30012009115059.p df $>$. Acesso em: 31 março 2014.

AZEVEDO, Antonio Junqueira de. Por uma nova categoria de dano na responsabilidade civil: o dano social. In: FILOMENO, José Geraldo Brito; WAGNER JÚNIOR, Luiz Guilherme da Costa; GONÇALVES, Renato Afonso (Coords.). O código civil e sua interdisciplinaridade. Belo Horizonte: Del Rey, 2004.

AZEVEDO, Cristina Maria do Amaral; AZEVEDO, Eurico de Andrade. A trajetória inacabada de uma regulamentação. Revista Eletrônica Com Ciência, SBPC, n. 26, 2000. Texto disponível em <http://www.comciencia.br/reportagens/biodiversidade/bio11.htm>. Acesso em: 31 março 2014.

AZEVEDO, Eurico de Andrade; AZEVEDO, Cristina Maria do Amaral. A trajetória inacabada de uma regulamentação. Revista Eletrônica Com Ciência, SBPC, n. 26, 2000. Texto disponível em <http://www.comciencia.br/reportagens/biodiversidade/bio11.htm>. Acesso em: 31 março 2014.

BASSO, Maristela. Os fundamentos atuais do direito internacional da propriedade intelectual. Revista Cej, Brasília, v. 21, 2003.

BENEVIDES FILHO, Maurício. A sanção premial no direito. Brasília: Brasília Jurídica, 1999.

BENJAMIN, Antonio Herman (Coord.). Dano ambiental: prevenção, reparação e repressão. São Paulo: RT, 1993.

BOBBIO, Norberto. Da estrutura à função: novos estudos de teoria do direito. Barueri: Manole, 2007. 
BORN, Rubens H.; TALOCCHI, Sérgio. Proteção do capital social e ecológico por meio de compensações por serviços ambientais (CSA). São Paulo: Peirópolis, 2002.

BOSON, Gerson de Britto Mello. Curso de direito internacional público. Belo Horizonte: Bernardo Álvares Editora, 1958.

BRASIL. Constituição Federal (1988). Disponível em $<$ http://www.planalto.gov.br/ccivil_03/constituicao/constituicao.htm>. Acesso em: 31 março 2014.

BRASIL. Decreto $\mathrm{n}^{\mathrm{o}}$ 6.514, de 22 de julho de 2008. Disponível em: $<$ http://www.planalto.gov.br/ccivil_03/_ato2007-2010/2008/decreto/D6514.htm>. Acesso em: 31 março 2014.

BRASIL. Decreto $\mathrm{n}^{\mathrm{o}}$ 7.829, de 17 de outubro de 2012. Disponível em: $<$ http://www.planalto.gov.br/ccivil_03/_Ato2011-2014/2012/Decreto/D7829.htm>. Acesso em: 31 março 2014.

BRASIL. Lei $\mathrm{n}^{\mathrm{o}}$ 6.938, de 31 de agosto de 1981. Disponível em: <http://www.planalto.gov.br/ccivil_03/leis/16938.htm>. Acesso em: 31 março 2014.

BRASIL. Lei $\mathrm{n}^{\mathrm{o}}$ 9.605, de 12 de fevereiro de 1998. Disponível em: $<$ http://www.planalto.gov.br/ccivil_03/leis/19605.htm>. Acesso em: 31 março 2014.

BRASIL. Lei $\mathrm{n}^{\mathrm{o}}$ 10.406, de 10 de janeiro de 2002. Disponível em: $<$ http://www.planalto.gov.br/ccivil_03/leis/2002/110406.htm>. Acesso em: 31 março 2014.

BRASIL. Lei $\mathrm{n}^{\mathrm{o}}$ 11.196, de 21 de novembro de 2005. Disponível em: $<$ http://www.planalto.gov.br/ccivil_03/_ato2004-2006/2005/lei/111196.htm>. Acesso em: 31 março 2014. 
BRASIL. Lei $\mathrm{n}^{\mathrm{o}}$ 11.428, de 22 de dezembro de 2006. Disponível em: $<$ http://www.planalto.gov.br/ccivil_03/_ato2004-2006/2006/lei/111428.htm>. Acesso em: 31 março 2014.

BRASIL. Lei $\mathrm{n}^{\mathrm{o}}$ 12.187, de 29 de dezembro de 2009. Disponível em: $<$ http://www.planalto.gov.br/ccivil_03/_ato2007-2010/2009/lei/112187.htm>. Acesso em: 31 março 2014.

BRASIL. Lei $\mathrm{n}^{\mathrm{o}} 12.305$, de 2 de agosto de 2010. Disponível em: $<$ http://www.planalto.gov.br/ccivil_03/_ato2007-2010/2010/1ei/112305.htm>. Acesso em: 31 março 2014.

BRASIL. Lei $\mathrm{n}^{\mathrm{o}}$ 12.414, de 9 de julho de 2011. Disponível em: $<$ http://www.planalto.gov.br/ccivil_03/_Ato2011-2014/2011/Lei/L12414.htm>. Acesso em: 31 março 2014.

BRASIL. Lei $\mathrm{n}^{\mathrm{o}}$ 12.512, de 14 de outubro de 2011. Disponível em: $<$ http://www.planalto.gov.br/ccivil_03/_ato2011-2014/2011/Lei/L12512.htm>. Acesso em: 31 março 2014.

BRASIL. Lei $\mathrm{n}^{\mathrm{o}}$ 12.651, de 25 de maio de 2012. Disponível em: $<$ http://www.planalto.gov.br/ccivil_03/_ato2011-2014/2012/lei/112651.htm>. Acesso em: 31 março 2014.

BRASIL. Lei $\mathrm{n}^{\mathrm{o}}$ 12.854, de 26 de agosto de 2013. Disponível em: $<$ http://www.planalto.gov.br/ccivil_03/_Ato2011-2014/2013/Lei/L12854.htm>. Acesso em: 31 março 2014.

BRASIL. Lei $\mathrm{n}^{\mathrm{o}}$ 11.284, de 2 de março de 2014. Disponível em: $<$ http://www.planalto.gov.br/ccivil_03/_ato2004-2006/2006/lei/111284.htm>. Acesso em: 31 março 2014.

BRASIL. Ministério do Trabalho e Emprego. Portaria Interministerial no 2, de 12 de maio de 2011. Disponível em: 
$<$ http://portal.mte.gov.br/data/files/8A7C816A2E7311D1012FFA7DD87E4E75/p_20110 512_2.pdf>. Acesso em: 31 março 2014.

BREGER, Marshall J.; ELLIOTT, E. Donald; HAWKINS, David; STEWART, Richard R. Providing economic incentives in environmental regulation. Faculty Scholarship Series. Paper 2206, 1991. Disponível em:

$<$ http://digitalcommons.law.yale.edu/cgi/viewcontent.cgi?article=3198\&context=fss_pap er>. Acesso em: 31 março 2014.

BUCCI, Maria Paula Dallari. O conceito da política pública em direito. Políticas públicas: reflexões sobre o conceito jurídico. São Paulo: Saraiva, 2006.

CABO FRIO. Lei Municipal $\mathrm{n}^{\mathrm{o}}$ 2.443, de 19 de junho de 2012. Disponível em: $<$ http://www.cmcabofrio.rj.gov.br>. Acesso em: 31 março 2014.

CABRAL, Neal. Exploring how today's development affects future generations around the globe: in this issue: sustainable directions in U.S. Environmental Law: The Role of Renewable portfolio standards in the context of a national carbon cap-and-trade program. Sustainable Development Law \& Policy, American University, 2007.

CACAIS, Rubens Capistrano. Cooperação internacional ambiental. In: MILARÉ, Édis; MACHADO, Paulo Affonso Leme (Orgs.). Direito ambiental: direito ambiental internacional e temas atuais. São Paulo: RT, 2011.

CAHALI, Yussef Said. Dano moral. São Paulo: RT, 2011.

CARVALHO, Paulo de Barros. Teoria da norma tributária. São Paulo: Max Limonad, 1998.

. Princípios e sobreprincípios na interpretação do direito. In: DE LUCCA, Newton; MEYER-PFLUG, Samantha Ribeiro; NEVES, Mariana Barboza (Coord.). Direito constitucional contemporâneo. São Paulo: Quartier Latin, 2012. 
CASELLA, Paulo Borba; ACCIOLY, Hildebrando; NASCIMENTO e SILVA, Geraldo Eulálio do. Manual de direito internacional público. 16. ed. São Paulo: Saraiva, 2008.

CLENDENNING, Greg; JACOBSEN, Grant; KOTCHEN, Matthew J. Community-based incentives for environmental protection: the case of green electricity. 2012. Disponível em: <http://environment.yale.edu/kotchen/pubs/community.pdf $>$. Acesso em: 31 março 2014.

COIMBRA, Ávila. O outro lado do meio ambiente. São Paulo: Millennium, 2002.

COSSIO, Carlos. La teoría egológica del derecho - su problema y sus problemas. Buenos Aires: Abeledo-Perrot, 1963.

COSTA, Pedro Moura. A convenção climática e o surgimento de commodities ambientais. Gazeta Mercantil, São Paulo, 1997.

CURITIBA. Lei Municipal nº 9.806, de 29 de março de 2010 de 2000. Disponível em: $<$ https://www.leismunicipais.com.br/a/pr/c/curitiba/lei-ordinaria/2000/980/9806/leiordinaria-n-9806-2000-institui-o-codigo-florestal-do-municipio-de-curitiba-revoga-asleis-n-8353-93-e-8436-94-e-da-outras-providencias.html>. Acesso em: 31 março 2014.

DAMASCENO, Monica. A Convenção-Quadro das Nações Unidas sobre mudança do clima. In: SOUZA, Rafael Pereira de (Organizador). Aquecimento global e créditos de carbono. São Paulo: Quartier Latin Brasil, 2007.

DAPICE, David. Thinking about the future: the complementary roles of economists and environmentalists. In: GOODWIN, Neva R. (Editor). As if the future mattered: translating social and economic theory into human behavior. Ann Arbor: University of Michigan Press, 1996.

DEMANGE, Lia Helena Monteiro de Lima. The principle of resilience. Pace Environmental Law Review. v. 30, nº 2, 2013, p. 695-810. 
DONEHOWER, Jonathan. Analyzing carbon emissions trading: a potential cost efficient mechanism to reduce carbon emissions. Environmental Law, 2008.

ELLIOTT, E. Donald; HAWKINS, David; STEWART, Richard R.; BREGER, Marshall J. Providing economic incentives in environmental regulation. Faculty Scholarship Series. Paper 2206, 1991. Disponível em:

$<$ http://digitalcommons.law.yale.edu/cgi/viewcontent.cgi?article=3198\&context=fss_pap er>. Acesso em: 31 março 2014.

FAZOLLI, Silvio Alexandre. Princípios ambientais tributários e a extrafiscalidade. Revista de Direito Ambiental, ano 9, n. 34. São Paulo: RT, 2004.

FERNANDES, Francisco. Dicionário Brasileiro Contemporâneo. 2. ed. São Paulo: Editora Globo, 1969.

FERRAZ JUNIOR, Tercio Sampaio. Introdução ao estudo do direito: técnica, decisão, dominação. São Paulo: Atlas, 2003.

FERREIRA, Aurélio Buarque de Hollanda. Pequeno Dicionário brasileiro da língua portuguesa. 11. ed. São Paulo: Editora Civilização Brasileira S.A., 1969.

FRANGETTO, Flavia Witkowski; GAZANI, Flavio Rufino. Viabilização jurídica do mecanismo de desenvolvimento limpo (MDL) no Brasil. São Paulo: Editora Peirópolis, 2002.

FREEMAN III, A. Myrick. Economics, Incentives and Environmental Regulation. In: VIG, Norman J.; KRAFT, Michael (Editors). Environmental policy: new directions for the twenty-first century. $4^{\text {th }}$ ed. Washington, D.C.: CQ Press, 2006, p. 190-209.

FREITAS, Gilberto Passos de. Direito penal ambiental. In: PHILIPPI JUNIOR, Arlindo; ALVES, Alaôr Caffé (Editores). Curso interdisciplinar de direito ambiental. Barueri: Manole, 2005. 
. A Constituição Federal e a efetividade das normas ambientais. Tese (Doutorado em Direito). Faculdade de Direito da Universidade Federal do Paraná. Curitiba, 1998.

FREITAS, Gilberto Passos de; FREITAS, Vladimir Passos de. Crimes contra a natureza. 8. ed. São Paulo: RT, 2006.

FREITAS, Vladimir Passos de; FREITAS, Gilberto Passos de. Crimes contra a natureza. 8. ed. São Paulo: RT, 2006.

FÜHRER, Maximilianus Cláudio Américo; MILARÉ, Édis. Manual de direito público \& privado. São Paulo: RT, 2005.

GAZANI, Flavio Rufino; FRANGETTO, Flavia Witkowski. Viabilização jurídica do mecanismo de desenvolvimento limpo (MDL) no Brasil. São Paulo: Editora Peirópolis, 2002.

GEHRING, Markus W.; NEWCOMBE, Andrew; SEGGER, Marie-Claire Cordonier (Editors). Sustainable development in world investment law. Alphen aan den Rijn, The Netherlands: Kluwer Law International; Frederick, MD: Sold and distributed in North, Central and South America by Aspen Publishers, 2011.

GOLDFINE, Stephanie. Using economic incentives to promote environmentally sound business practices: A look at germany's experience with its regulation on the avoidance of packaging waste. HeinOnline, 7 Geo. Int'l Envtl. L. Rev. 309, 1994. Disponível em: $<$ www.heinonline.org>. Acesso em: 31 março 2014.

GRAU NETO, Werner. O novo paradigma indutor do trato tributário da questão ambiental: do poluidor-pagador ao princípio da sustentabilidade. In: LECEY, Eladio Luiz da Silva; CAPPELLI, Silvia (Coords.) Revista de Direito Ambiental, n. 64. São Paulo: RT, 2011, p. 11-27.

GUAÍRA. Lei Municipal $\mathrm{n}^{\circ}$ 2.491, de 2 de março de 2011. Disponível em: $<$ http://www.camara-guaira.sp.gov.br/camver/LEIMUN/2011/02491.pdf>. Acesso em: 31 março 2014. 
GUARULHOS. Lei Municipal $n^{0}$ 6.793, de 28 de dezembro de 2010. Disponível em: $<$ http://leis.guarulhos.sp.gov.br/06_prefeitura/leis/leis_download/06793lei.pdf $>$. Acesso em: 31 março 2014.

HANLEY, Nick; SHOGREN, Jason; WHITE, Ben. Environmental economics in theory and practice. New York: Oxford University Press, 1997.

HAWKINS, David; STEWART, Richard R.; BREGER, Marshall J.; ELLIOTT, E. Donald. Providing economic incentives in environmental regulation. Faculty Scholarship Series. Paper 2206, 1991. Disponível em:

$<$ http://digitalcommons.law.yale.edu/cgi/viewcontent.cgi?article=3198\&context $=$ fss_pap er>. Acesso em: 31 março 2014.

HERCOWITZ, Marcelo; MATTOS, Luciano. Pontos fundamentais para o desenho de políticas públicas de serviços ambientais voltadas às populações tradicionais e povos indígenas. In: NOVION, Henry; VALLE, Raul (Editores). É pagando que se preserva? Documentos ISA. São Paulo: Instituto Socioambiental, n. 10, 2009.

HIRSCH, Dennis. Proceedings from the symposium on the law and policy of ecosystem services: Trading in ecosystem services: Carbon and the clean development mechanism. Florida State University, 2007.

IHERING, Rudolf Von. A luta pelo direito. 16. ed. Rio de Janeiro: Forense, 1998. . A finalidade do direito. Campinas: Bookseller, 2002.

JACOBSEN, Grant; KOTCHEN, Matthew J.; CLENDENNING, Greg. Communitybased incentives for environmental protection: the case of green electricity. 2012. Disponível em: $<$ http://environment.yale.edu/kotchen/pubs/community.pdf $>$. Acesso em: 31 março 2014.

KELSEN, Hans. Teoria pura do direito. São Paulo: Martins Fontes, 2000. 
KNOLL, Michael S. Products liability and legal leverage. The perverse effect of stiff penalties. UCLA - University of California Los Angeles - Law Review, v. 45, n. 1, oct. 1997.

KOTCHEN, Matthew J.; CLENDENNING, Greg; JACOBSEN, Grant. Communitybased incentives for environmental protection: the case of green electricity. 2012. Disponível em: <http://environment.yale.edu/kotchen/pubs/community.pdf $>$. Acesso em: 31 março 2014.

KRAFT, Michael E.; VIG, Norman J (Editors). Environmental policy: new directions for the twenty-first century. $4^{\text {th }}$ ed. Washington, D.C.: CQ Press, 2006.

KRAFT, Steven E.; LANT, Christopher L.; RUHL, J. B. The Law and Policy of Ecosystem Services. Washington: Island Press, 2007.

KUBASEK, Nancy K.; SILVERMAN, Gary S. Environmental law. 2. ed. Upper Saddle River, N. J.: Prentice-Hall, 1997.

LANT, Christopher L.; RUHL, J. B.; KRAFT, Steven E. The Law and Policy of Ecosystem Services. Washington: Island Press, 2007.

LEFF, Enrique. Racionalidade ambiental: a reapropriação social da natureza. Trad. Luís Carlos Cabral. Rio de Janeiro: Civilização Brasileira, 2006.

LEITE, José Rubens Morato. Dano ambiental: do individual ao coletivo extrapatrimonial. São Paulo: RT, 2000.

LEMOS, Patrícia Faga Iglecias. Direito ambiental: responsabilidade civil e proteção ao meio ambiente. 3. ed. São Paulo: RT, 2010.

. Meio ambiente e responsabilidade civil do proprietário: análise do nexo causal. São Paulo: RT, 2008. 
LITTLE, Paul. Os desafios da política ambiental no Brasil. In: LITTLE, Paul. (Org.). Políticas ambientais no Brasil. Análises, instrumentos e experiências. São Paulo: Editora Peirópolis, 2003.

LOPEZ, Teresa Ancona. Princípio da precaução e evolução da responsabilidade civil. São Paulo: Quartier Latin, 2010.

LÓPEZ, José Manuel Castillo. La reforma fiscal ecológica. Granada: Camares, 1999.

MARCHI, Eduardo Cesar Silveira Vita. Guia de metodologia jurídica: teses, monografia e artigos. Lecce-Italy: Edizioni Del Grifo, 2002.

MARINHO, Yuri Rugai. A lei de crimes ambientais frente à evolução do direito ambiental: sanções versus incentivos. In: ALVAREZ, Albino Rodrigues; MOTA, José Aroudo (Orgs.). Sustentabilidade ambiental no Brasil: biodiversidade, economia e bemestar humano. Brasília: IPEA, 2010.

. Créditos de carbono: incentivo do direito internacional ambiental. Monografia (Graduação em Direito). Faculdade de Direito da Universidade de São Francisco. São Paulo, 2008.

MARTINS-COSTA, Judith; PARGENDLER, Mariana Souza. Usos e abusos da função punitiva (punitive damages e o direito brasileiro). Revista CEJ, n. 28. Brasília, 2005, p. $15-32$.

MATTOS, Luciano; HERCOWITZ, Marcelo. Pontos fundamentais para o desenho de políticas públicas de serviços ambientais voltadas às populações tradicionais e povos indígenas. In: NOVION, Henry; VALLE, Raul (Editores). É pagando que se preserva? Documentos ISA. São Paulo: Instituto Socioambiental, n. 10, 2009.

MAY, Peter H.; AMARAL, Carlos; MILlIKAN, Brent; ASCHER, Petra (Orgs.). Instrumentos econômicos para o desenvolvimento sustentável da Amazônia brasileira. Brasília: Ministério do Meio Ambiente, 2005. Disponível em: 
<http://www.mma.gov.br/estruturas/168/_publicacao/168_publicacao30012009115059.p df>. Acesso em: 31 março 2014.

MAY, Peter H. Introdução. In: MAY, Peter H.; AMARAL, Carlos; MILLIKAN, Brent; ASCHER, Petra (Orgs.). Instrumentos econômicos para o desenvolvimento sustentável da Amazônia brasileira. Brasília: Ministério do Meio Ambiente, 2005. Disponível em: $<$ http://www.mma.gov.br/estruturas/168/_publicacao/168_publicacao30012009115059.p df>. Acesso em: 31 março 2014.

MICHAEL, Ash. Taxation, innovation and the environment. Paris: OECD, 2010.

MILARÉ, Édis. Direito do ambiente. 6. ed. São Paulo: RT, 2009. ; FÜHRER, Maximilianus Cláudio Américo. Manual de direito público \& privado. São Paulo: RT, 2005.

; COSTA JÚNIOR, Paulo José da. Direito penal ambiental: comentários à Lei $\mathrm{n}^{\circ}$ 9.605/98. Campinas: Millennium, 2002.

MILLIKAN, Brent; AMARAL, Carlos; MAY, Peter H.; ASCHER, Petra (Orgs.). Instrumentos econômicos para o desenvolvimento sustentável da Amazônia brasileira. Brasília: Ministério do Meio Ambiente, 2005. Disponível em: $<$ http://www.mma.gov.br/estruturas/168/_publicacao/168_publicacao30012009115059.p df>. Acesso em: 31 março 2014.

MINAS GERAIS. Lei Estadual $\mathrm{n}^{\circ}$ 20.922, de 16 de outubro de 2013. Disponível em: $<$ http://www.almg.gov.br/consulte/legislacao/completa/completa-novamin.html tipo $=$ LEI\&num $=20922 \&$ comp $=\& a n o=2013 \&$ texto $=$ original $>$. Acesso em: 31 março 2014.

MIRRA, Álvaro Luiz Valery. Fundamentos do direito ambiental no Brasil. Revista dos Tribunais, n. 706. São Paulo: RT, 1994, p. 7-29. 
MOTTA, Ronaldo S. da. Instrumentos econômicos e política ambiental. In: LECEY, Eladio Luiz da Silva; CAPPELLI, Silvia (Coords.) Revista de Direito Ambiental, n. 20. São Paulo: RT, 2000.

MUKAI, Toshio; NAZO, Georgette Nacarato. O direito ambiental no Brasil: evolução histórica e a relevância do direito internacional do meio ambiente. In: MILARÉ, Édis; MACHADO, Paulo Affonso Leme (Orgs.). Direito ambiental: direito ambiental internacional e temas atuais. São Paulo: RT, 2011.

NASCIMENTO e SILVA, Geraldo Eulálio do; ACCIOLY, Hildebrando; CASELLA, Paulo Borba. Manual de direito internacional público. 16. ed. São Paulo: Saraiva, 2008.

NAZO, Georgette Nacarato; MUKAI, Toshio. O direito ambiental no Brasil: evolução histórica e a relevância do direito internacional do meio ambiente. In: MILARÉ, Édis; MACHADO, Paulo Affonso Leme (Org.). Direito ambiental: direito ambiental internacional e temas atuais. São Paulo: RT, 2011.

NEWCOMBE, Andrew; SEGGER, Marie-Claire Cordonier; GEHRING, Markus W. (Editors). Sustainable development in world investment law. Alphen aan den Rijn, The Netherlands: Kluwer Law International; Frederick, MD: Sold and distributed in North, Central and South America by Aspen Publishers, 2011.

NINO, Carlos Santiago. Introdución al análisis del derecho. Barcelona: Ariel, 1983.

NOWICKI, Meghan. Implementing sustainable industrial development in the united states and abroad: the need for legislation and international cooperation. 62 Ala. L. Rev. 1093. 2010-2011.

NUSDEO, Ana Maria de Oliveira. Pagamento por serviços ambientais: sustentabilidade e disciplina jurídica. São Paulo: Atlas, 2012.

. Utilização de instrumentos econômicos nos países integrantes e no âmbito do TCA: experiência, limitações e potencialidades. Anais do XV Congresso Nacional do 
CONDEPI: direito, sociobiodiversidade e soberania na Amazônia, Florianópolis: Fundação Boiteux, 2007.

. O uso de instrumentos econômicos nas normas de proteção ambiental. In: NUSDEO, Ana Maria de Oliveira (Org.). Revista da Faculdade de Direito da Universidade de São Paulo, São Paulo, v. 101, p. 357-378, jan./dez., 2006.

NUSDEO, Fábio. Desenvolvimento e ecologia. São Paulo: Saraiva, 1975.

PAEHLKE, Robert C. Environmental Values and Public Policy. In: VIG, Norman J.; KRAFT, Michael (Editors). Environmental policy: new directions for the twenty-first century. $4^{\text {th }}$ ed. Washington, D.C.: CQ Press, 2006, p. 77-97.

PARÁ. Decreto Estadual $\mathrm{n}^{\mathrm{o}}$ 775, de 26 de julho de 2013. Disponível em: $<$ http://www.alepa.pa.gov.br/alepa/arquivos/bleis/bancodeleis12-0235b8b.pdf $>$. Acesso em: 31 março 2014.

PARÁ. Lei Estadual $\mathrm{n}^{\mathrm{o}}$ 7.638, de 12 de julho de 2012. Disponível em: $<$ http://www.alepa.pa.gov.br/alepa/arquivos/bleis/bancodeleis12-02A1A14.pdf $>$. Acesso em: 31 março 2014.

PARGENDLER, Mariana Souza; MARTINS-COSTA, Judith. Usos e abusos da função punitiva (punitive damages e o direito brasileiro). Revista CEJ, n. 28. Brasília, 2005, p. $15-32$.

PEREIRA, Caio Mário da Silva. Responsabilidade civil. Rio de Janeiro: Forense, 2012.

PERCIVAL, Robert V.; ALEVIZATOS, Dorothy C. (Editors). Law and the environment: a multidisciplinary reader. Philadelphia: Temple University Press, 1997.

PLATER, Zygmunt J.B. et al. Environmental law and policy: nature, law, and society. $4^{\text {th }}$ ed. New York: Aspen Publishers; Austin: Wolters Kluwer Law \& Business, 2010. 
POLINSKY, A. Mitchell. An introduction to law and economics. Boston: Little, Brown and Company, 1989.

PRADO, Luiz Regis. Direito penal do ambiente. 2. ed. São Paulo: RT, 2009.

Crimes contra o meio ambiente. 2. ed. São Paulo: RT, 2001.

. Princípios penais de garantia e a nova lei ambiental. Boletim IBCCRIM, edição especial do IV Seminário Internacional do IBCCRIM. São Paulo, IBCCRIM, n. 70, 1998, p. $10-23$.

QUEIROZ, João Eduardo Lopes; SANTOS, Márcia Walquiria Batista dos. Direito administrativo econômico. São Paulo: Atlas, 2011.

REHBINDER, Eckard. Environmental regulation through fiscal and economic incentives in a federalist system. HeinOnline, 20 Ecology L.Q. 57, 1993. Disponível em: <www.heinonline.org>. Acesso em: 31 março 2014.

REVESZ, Richard; SANDS, Philippe; STEWART, Richard B. Environmental law, the economy, and sustainable development: the United States, the European Union, and the international community. New York: Cambridge University Press, 2000.

REZEK, José Francisco. Direito dos tratados. Rio de Janeiro: Editora Forense, 1984.

. Direito internacional público. 13 ed. São Paulo: Saraiva, 2011.

RUHL, J. B.; KRAFT, Steven E.; LANT, Christopher L. The law and policy of ecosystem services. Washington: Island Press, 2007.

SACHS, Ignacy. Desenvolvimento includente, sustentável, sustentado. Rio de Janeiro: Garamond, 2004. 
SANDS, Philippe; REVESZ, Richard; STEWART, Richard B. Environmental law, the economy, and sustainable development: the United States, the European Union, and the international community. New York: Cambridge University Press, 2000.

SANTOS, Márcia Walquiria Batista dos; QUEIROZ, João Eduardo Lopes. Direito administrativo econômico. São Paulo: Atlas, 2011.

SÃO BERNARDO DO CAMPO. Lei Municipal $n^{\circ}$ 6.091, de 9 de dezembro de 2010. Disponível em: <https://www.leismunicipais.com.br/a2/sp/s/sao-bernardo-do-campo/leiordinaria/2010/609/6091/lei-ordinaria-n-6091-2010-disciplina-a-concessao-de-beneficiofiscal-aos-imoveis-com-area-de-cobertura-vegetal-ou-destinados-a-producaohortifrutigranjeira-e-da-outras-providencias.html?wordkeytxt=6091>. Acesso em: 31 março 2014.

SÃO PAULO. Decreto Estadual $n^{\circ}$ 55.947, de 24 de junho de 2010. Disponível em: $<$ http://www.al.sp.gov.br/norma/?id=159791>. Acesso em: 31 março 2014.

SÃO PAULO. Decreto Estadual $n^{\circ}$ 59.260, de 5 de junho de 2013. Disponível em: <http://www.al.sp.gov.br/norma/?id=170434>. Acesso em: 31 março 2014.

SÃO PAULO. Lei Estadual $n^{\circ} 13.798$, de 9 de novembro de 2009. Disponível em: $<$ http://www.al.sp.gov.br/norma/?id=158351>. Acesso em: 31 março 2014.

SÃO PAULO. Lei Estadual $\mathrm{n}^{\mathrm{o}}$ 11.160, de 18 de junho de 2002. Disponível em: $<$ http://www.al.sp.gov.br/norma/?id=138>. Acesso em: 31 março 2014.

SÃO PAULO. Secretaria do Meio Ambiente. Resolução n 123, de 23 de dezembro de 2010. Disponível em: <http://www.ambiente.sp.gov.br/legislacao/resolucoessma/resolucao-sma-123-2010/>. Acesso em: 31 março 2014.

SÃO PAULO. Secretaria do Meio Ambiente. Resolução no 37, de 5 de junho de 2012. Disponível em: <http://www.ambiente.sp.gov.br/legislacao/resolucoes-sma/resolucaosma-37-2012/>. Acesso em: 31 março 2014. 
SÃO VICENTE. Lei Complementar Municipal no 634, de 5 de novembro de 2010. Disponível em: <http://www.saovicente.sp.gov.br/ambiental/pdf_12/04/634.pdf>. Acesso em: 31 março 2014.

SCHOUERI, Luís Eduardo. Normas tributárias indutoras em matéria ambiental. In: TORRES, Heleno Taveira (Org.). Direito tributário ambiental. São Paulo: Malheiros, 2005.

SEGGER, Marie-Claire Cordonier; GEHRING, Markus W.; NEWCOMBE, Andrew (Editors). Sustainable development in world investment law. Alphen aan den Rijn, The Netherlands: Kluwer Law International; Frederick, MD: Sold and distributed in North, Central and South America by Aspen Publishers, 2011.

SEIDENFELD, Mark. Microeconomic predicates to law and economics. Cincinnati: Anderson Publishing Company, 1996.

SHOGREN, Jason; WHITE, Ben; HANLEY, Nick. Environmental economics in theory and practice. New York: Oxford University Press, 1997.

SILVA, Enio Moraes da. Os organismos geneticamente modificados e o princípio da precaução como instrumento de proteção ambiental. In: MILARÉ, Édis; MACHADO, Paulo Affonso Leme (Orgs.). Direito Ambiental: direito ambiental internacional e temas atuais. São Paulo: RT, 2011.

SILVERMAN, Gary S.; KUBASEK, Nancy K. Environmental law. 2. ed. Upper Saddle River, N. J.: Prentice-Hall, 1997.

SOARES, Guido Fernando da Silva. A proteção internacional do meio ambiente. São Paulo: Manole, 2003. . Curso de direito internacional público. 2. ed. São Paulo: Atlas, 2002.

- Direito internacional do meio ambiente: emergência, obrigações e responsabilidades. São Paulo: Atlas, 2001. 
. Direitos humanos e meio ambiente. In: JÚNIOR, Alberto do Amaral; PERRONEMOISÉS, Cláudia (Org.). O Cinquentenário da Declaração Universal dos Direitos do Homem. São Paulo: EDUSP, 1999.

SODRÉ, Marcelo Gomes. Padrões de consumo e meio ambiente. In: MARQUES, Claudia Lima (Coord.). Revista de Direito do Consumidor, n. 31. São Paulo: RT, 1999, p. 24-78.

SOROCABA. Lei Municipal $n^{\circ}$ 9.571, de 16 de maio de 2011. Disponível em: $<$ http://www.camarasorocaba.sp.gov.br/sitecamara/proposituras/verpropositura $>$. Acesso em: 31 março 2014.

STEWART, Richard R.; BREGER, Marshall J.; ELLIOTT, E. Donald; HAWKINS, David. Providing economic incentives in environmental regulation. Faculty Scholarship Series. Paper 2206, 1991. Disponível em:

$<$ http://digitalcommons.law.yale.edu/cgi/viewcontent.cgi?article $=3198 \&$ context $=$ fss_pap er>. Acesso em: 31 março 2014.

REVESZ, Richard; SANDS, Philippe. Environmental law, the economy, and sustainable development: the United States, the European Union, and the international community. New York: Cambridge University Press, 2000.

Economic incentives for environmental protection: Opportunities and Obstacles. In: REVESZ, Richard; SANDS, Philippe; STEWART, Richard B. Environmental law, the economy, and sustainable development: the United States, the European Union, and the international community. New York: Cambridge University Press, 2000.

TALOCCHI, Sérgio; BORN, Rubens H. Proteção do capital social e ecológico por meio de compensações por serviços ambientais (CSA). São Paulo: Peirópolis, 2002.

TORRES, Heleno Taveira (Org.). Direito tributário ambiental. São Paulo: Malheiros Editores, 2005. 
TRENNEPOHL, Curt. Infrações contra o meio ambiente. Minas Gerais: Fórum, 2006.

TRENNEPOHL, Terence Dorneles. Incentivos fiscais no direito ambiental: para uma matriz energética limpa e o caso do etanol brasileiro. São Paulo: Saraiva, 2011.

TUPIASSU, Lise Vieira da Costa. Tributação ambiental: a utilização de instrumentos econômicos e fiscais na implementação do direito ao meio ambiente saudável. Rio de Janeiro: Renovar, 2006.

U.S. Congress, Office of Technology Assesment, Environmental Policy Tools: A User's Guide. OTAENV-634 (Washington, D.C.: U.S. Government Printing Office, September, 1995. In PERCIVAL, Robert; ALEVIZATOS, Dorothy (Editors). Law and the environment: a multidisciplinary reader. Temple University Press, Philadelphia, 1997.

VIG, Norman J.; KRAFT, Michael E (Editors). Environmental policy: new directions for the twenty-first century. $4^{\text {th }}$ ed. Washington, D.C.: CQ Press, 2006.

VILA VELHA. Lei Municipal $n^{0}$ 4.864, de 29 de dezembro de 2009. Disponível em: $<$ http://www.legislacaoonline.com.br/vilavelha/images/leis/html/L48642009.html>. Acesso em: 31 março 2014.

WAINER, Ann Helen. Legislação ambiental do Brasil - Subsídios para a história do direito ambiental. Rio de Janeiro: Forense, 1991.

WHITE, Ben; HANLEY, Nick; SHOGREN, Jason. Environmental economics in theory and practice. New York: Oxford University Press, 1997.

WUNDER, Sven. Payments for environmental services: some nuts and bolts. CIFOR Occasional Paper, Jacarta: Center for International Forestry Research n. 42, 2005. Disponível em: $\quad<$ http://www.cifor.cgiar.org/publications/pdf_files/OccPapers/OP42.pdf>. Acesso em: 31 março 2014.

YOSHIDA, Consuelo Yatsuda Moromizato. A efetividade e a eficiência ambiental dos instrumentos econômico-financeiros e tributários. Ênfase na prevenção. A utilização 
econômica dos bens ambientais e suas implicações. In: TORRES, Heleno Taveira (Org.).

Direito Tributário Ambiental. São Paulo: Malheiros, 2005. 